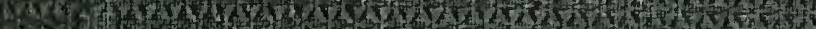

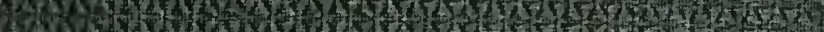

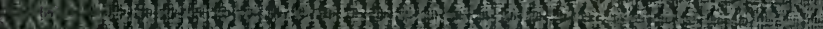
3 (x) Let in Tix

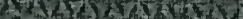
- iv

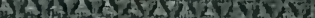

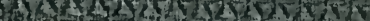

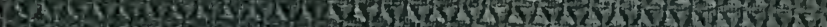
W.

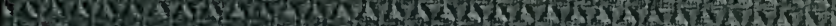

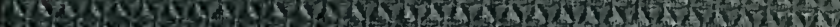

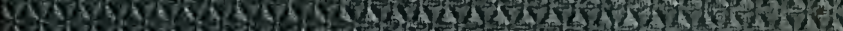

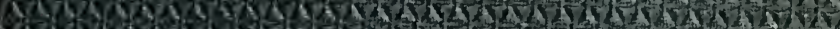
rowas

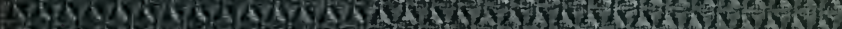

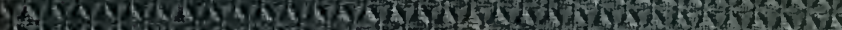

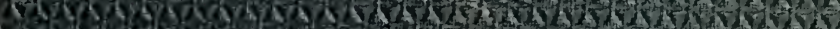

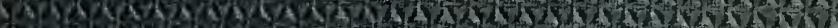

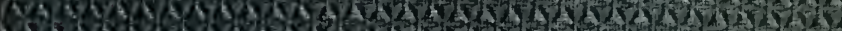

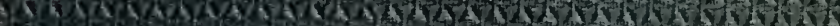

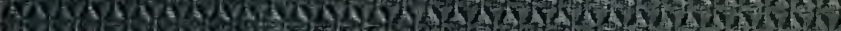

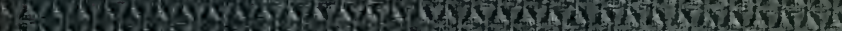

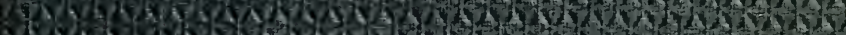
92 yos.

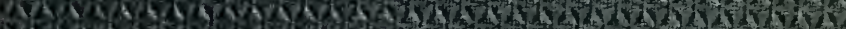
'5.

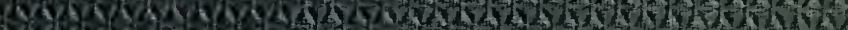

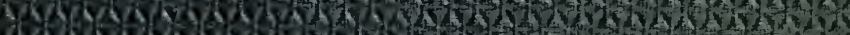

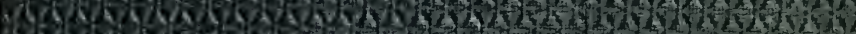

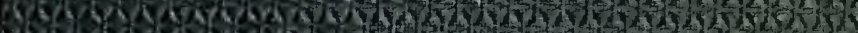

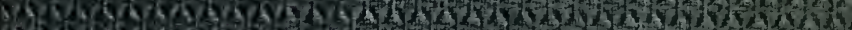

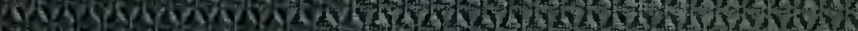
Yos

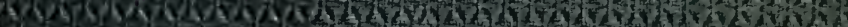

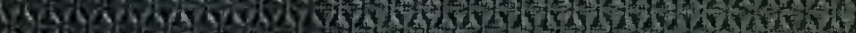

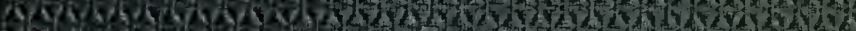

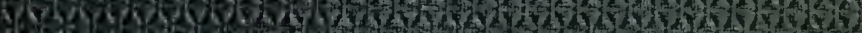

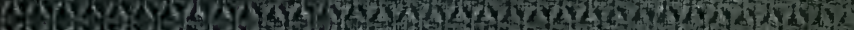

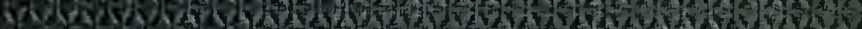

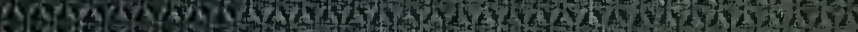

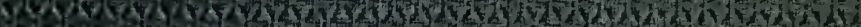

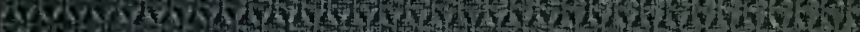

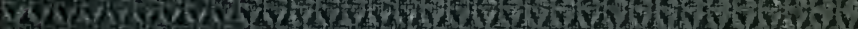
LWV

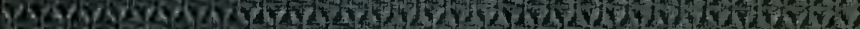

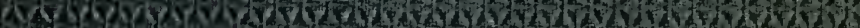
Y)

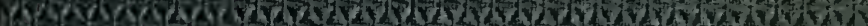

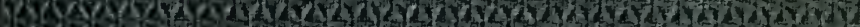

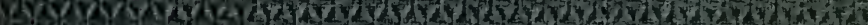

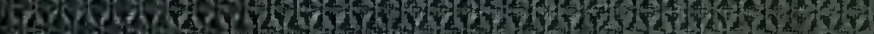

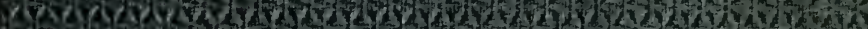
47.

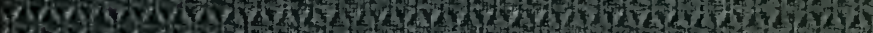

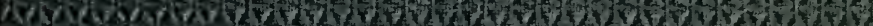
(t) 27w

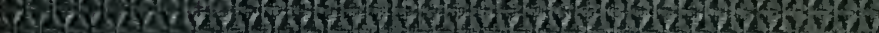

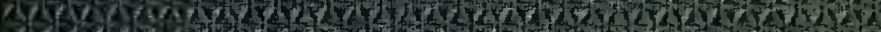

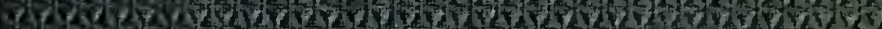

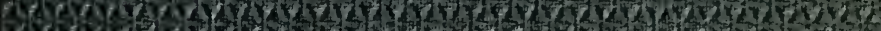

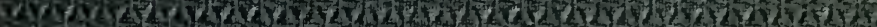

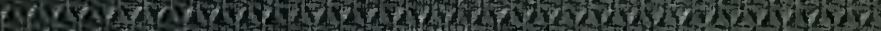

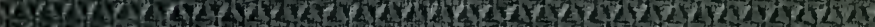

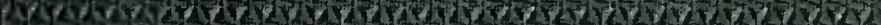

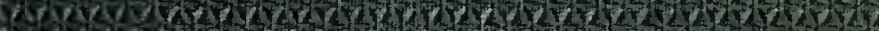

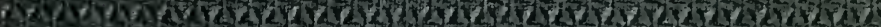

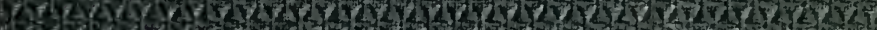

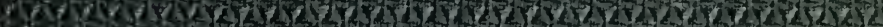

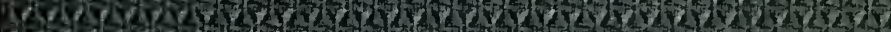
gFry.

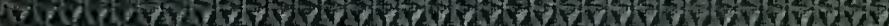

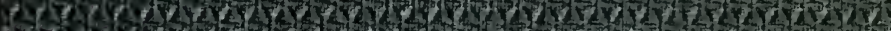

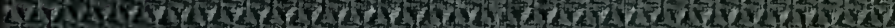

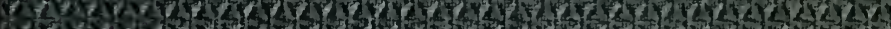

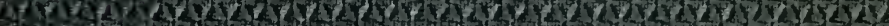

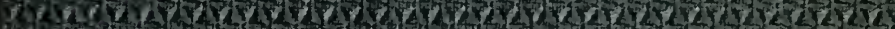

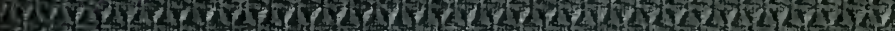
17 2. H.

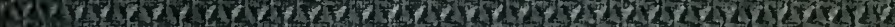

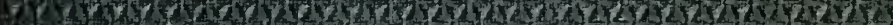
6.

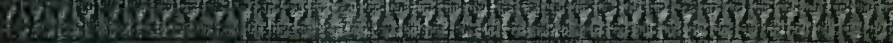




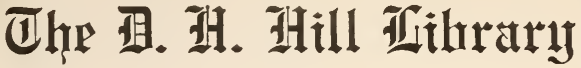

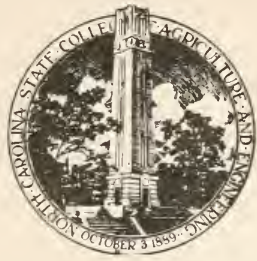

Airtḥ Carnlina State Crallege

QH487 S5? 
QH48?

On a true par genesis in mot

\begin{tabular}{|l|l|}
\hline DATE & BeES ISSUED TO \\
\hline & \\
\hline & \\
\hline & \\
\hline & \\
\hline & \\
\hline & \\
\hline & \\
\hline & \\
\hline & \\
\hline & \\
\hline & \\
\hline & \\
\hline & \\
\hline
\end{tabular}

This book may be kept out TWO WEEKS ONLY, and is subject to a fine of FIVE CENTS a day thereafter. It is due on the day indicated below:

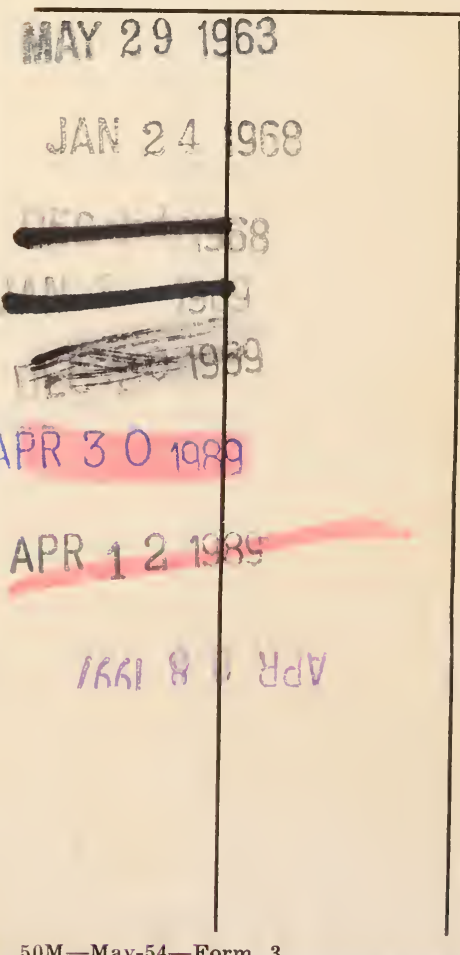




\title{
ON
}

\section{A TRUE PARTIIENOGENESIS}

\author{
IN MOTHS AND BEES;
}

A CONTRIBUTION TO

THE HISTORY OF REPRODUCTION IN ANIMALS.

BY

CARL THEODOR ERNST VON SIEBOLD,

Professor of Zoology and Comparative Anatomy in the University of Munich, Knight of the Order of Maximilian, Director of the Zoological and Zootomical

Cabinet, and Conservator of the Zoological Institute in Munich.

TRANSLATED BY

WILLIAM S. DALLAS, F.L.S. \&C.

L O N D O N :

JOHN VAN VOOLST, PATERNOSTER ROW. 
Non semel quædam sacra traduntur! Eleusin servat quod ostendat revisentibus. Rerum natura sacra sua non simul tradit. Initiatos nos credinus: in restibulo ejns hæremus. Illa arcana non promiscue nec omnibus patent: reducta et in interiore sacrario clausa sunt. Ex quibus alind hæc ætas, aliud, quæ post nos subibit, dispiciet._Seneca (Natural. Quastion. lib. vii. 31). 


\section{PRE A C E.}

Evgaged in constant efforts to trace and clear up the history of animal reproduction, as far as this is permitted to human discernment, I have been guided to a phænomenon in Insectlife which had for a long time remained obscure to me,-I refer to the power of reproduction of some female Insects which remain unfecundated, as this not only appeared to be a great mystery, but even a fact never yet firmly established, and therefore still doubtful. I always found this so-called Lucina sine concubitu treated by physiologists as a sort of curiosity; the same examples from Insect-life, derived from the older observers, were constantly referred to as vouchers. The question, whether the fact referred to was supported upon a firm basis, remained at the same time altogether unnoticed. As every kind of statement with regard to Lucina sine concubitu was received with so little caution and without suspicion, new observations were added to the older defective notices of this kind; but these, in the same way, appeared inadmissible as soon as they were carefully analysed.

Since the process of the fecundation of the egg has become much better understood by the recent discoveries of Newport, Keber, Bischoff, Leuckart, Meissner, and Bruch, one was compelled to say, that all the cases of Lucina sine concubitu observed in former or modern days might be founded upon delusion or error, because up to this time the knowledge of the conditions under which fecundation takes place was still extremely imperfect. Now, when the physiology of reproduction has been enriched with many exceedingly important discoverics, and by these some essential points in the act of fecundation, 
which had been previously overlooked, have been brought to light, very different claims are made upon those observations, by which it is to be decided, whether an egg which has arrived at development was or was not fecundated.

For this reason I was not to be blamed if I made my first appearance as a sceptic, and submitted this subject to an examination corresponding with the present fundamental laws of Physiology. The results of this examination, contrary to expectation, have furnished the proof :-1. that a Lucina sine concubitu does exist; and 2. that this does not merely start up here and there accidentally, as was formerly supposed, but that it occupies its perfectly definite position in nature. It is true that it still remains concealed from us, according to what laws and under what motives this remarkable mode of reproduction has obtained the place assigned to it in the history of reproduction.

In these investigations, to which I have devoted the careful study of many years, I was very readily and disinterestedly assisted by various naturalists, who, partly by providing me with the materials necessary for such investigations and observations, but partly also by communicating their own multifarious experience upon the department in question, put me in a position to obtain as wide a glance as possible over this still imperfectly explored field. I therefore regard it as my duty to express my public thanks here to Baron von Berlepsch of Seebach, MM. Bremi of Zurich, Dzierzon of Carlsmarkt, Professor F. de Filippi of Turin, Dr. Herrich-Schäffer of Ratisbon, Senator von Heyden of Frankfort a. M., M. Kollar, Director of the Imperial Cabinet at Vienna, MM. Radlkofer of Munich, Reutti of Freiburg, Dr. Rosenhauer of Erlangen, A. Schmid of Eichstadt, Steiner of Breslau, and Professor Zeller of Glogau, for the assistance which they rendered me in my investigations.

$$
\text { C. T. E. von SIEBOLd. }
$$

Munich, 25th March 1856. 


\section{'TRANSLATOR'S PREFACE.}

OF all the discoveries which have been made of late years in the history of the reproduction of animals, none is of greater importance than that of the entrance of the spermatozoids into the ovum, which is found to be the rule not only in the Animal, but also in the Vegetable Kingdom. Nevertheless, but a few years have elapsed since the final settlement of this disputed question, and we have in the following observations of Professor Siebold a clear proof of the occurrence of phænomena, which, if they do not invalidate the law, at least show that it is liable to some, probably to many exceptions.

Several years ago our author published some observations upon a species of Psyche, which, as he stated, propagated without copulation. He referred this singular occurrence to the same class of phænomena as the asexual reproduction of the Aphides, the so-called Alternation of Generations; and although it must have been evident to every one who attentively studied his paper that the circumstances of the two cases were widely different, it was impossible, in the state of our knowledge at the time, to propose any more satisfactory explanation of the phænomenon. Now, however, the whole face of affairs is changed. Von Siebold, as will be seen in the following pages, has clearly proved the existence of a sexual reproduction without fecundation, not only in the Psychide, to which his former observations related, but also in the Bees,-in both as a regular occurrence, and as an occasional phænomenon also in the Silk-worm Moth; the latter circumstance giving a considerable degree of probability to some even of those supposed cases which our author discusses and rejects as inadmissible in the first section of his book. - For this phænomenon of reproduction by virgin females the author adopts the term Parthenogenesis, originally proposed by 
Professor Owen to express the dissimilar Digenesis or Alternation of Generations.

That the same thing occurs in other species of animals besides those upon which the author's observations have been made, there can be no doubt, and, in fact, several of these are indicated in his concluding remarks. Of some of the Entomostracous Crustacea no males have yet been detected, whilst the females of others have been observed to propagate without concourse with the male. A still more striking instance is afforded by the Gall-flies belonging to the restricted genus Cynips, of which several species are very common in Europe, and yet amongst the thousands which have been reared from galls, not a single male has ever been seen. An oak-gall has been found in great quantities of late in Devonshire, which has attracted considerable attention from those few Entomologists in this country who trouble themselves with the study of Hymenoptera. It is produced by a species of Cynips, and all the specimens, to the number of several hundreds, which have been reared, confirm the above statement as to the absence of males. Some experiments now being made by Mr. Smith of the British Museum, whose tact and power of observation so thoroughly fit him for the investigation of such a point, will probably soon determine whether these Insects are also to be cited in support of the interesting and important theory developed by Von Siebold in the following pages. Âmongst the Entozoa, we may also probably meet with further instances of Parthenogenesis, as their propagation, notwithstanding the great advances that have of late been made in our knowledge of its phænomena, still presents much that is enigmatical.

But it is not only in the Animal Kingdom that we meet with this phænomenon of ovular reproduction without impregnation : similar instances occur also amongst the Phanerogamous plants. Many years ago, Camerarius and Spallanzani asserted that the female Hemp was capable of producing fertile seed without the aid of the male pollen; and a French botanist, M. Lecoq, has lately addressed a note to the Academy of Sciences, referring to some experiments made by him, and published in 1827, upon the same subject. His experiments were made upon various diocious plants, amongst which Hemp, Spinach, Mercurialis 
annua, and Trinia vulgaris furnished him with fertile seeds, although every precaution was taken to isolate the plants. (See Comptes Rendus, 8th December, 1856, p. 1069.) A diøcious Euphorbiaceous plant also, the Colebogyne, from Australia, has produced fertile seeds in the Botanic Gardens at Kew, although only the female is known to botanists.

Interesting as this curious discovery of Von Siebold's must be to the Physiologist, there are some points connected with it which render it of the highest practical importance to the keepers of Bees. The greater part of the following pages is devoted to the consideration of the wonderful series of phænomena presented by the reproduction of those industrious Insects, and the intelligent Bee-keeper will find that by studying it he will obtain many hints, which, if properly applied in practice, may enable him not merely to study the habits of his interesting charges with much greater satisfaction than heretofore, but also, by proper management, to increase the profits derivable from his hives, - a consideration which may perhaps have more weight with many than any of a purely theoretical nature.

Although I cannot flatter myself that I have done full justice to the exceedingly happy phraseology in which Professor von Siebold has communicated his results to the world, I have endeavoured as far as lay in my power to adhere strictly to the original, so that the English reader might at least be sure of getting the true sense of the author.

The proof-sheets have been submitted to Professor Owen, who has kindly enriched them with some valuable notes, of which those relating to Hunter's views are especially interesting. The additional notes are all included between brackets.

W. S. DALLAS.

London, 20th January, 1857. 


\section{CONTENTS.}

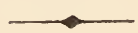

Page

Introduction $\ldots \ldots \ldots \ldots \ldots \ldots \ldots \ldots \ldots \ldots \ldots \ldots \ldots$

Elucidation of the Cases hitherto described as Parthenogenesis . . 12

True Parthenogenesis in some Sac-bearing Lepidoptera ....... 24

True Parthenogenesis in the Honey-Bee ............ 38

True Parthenogenesis in the Silk-worm Moth .......... 92

Concluding Remarks ${ }^{2} \ldots \ldots \ldots \ldots \ldots \ldots \ldots \ldots \ldots \ldots \ldots$

Explanation of the Figures. ................ 109 


\section{TRUE PARTHENOGENESIS.}

\section{INTRODUCTION.}

IT is high time that Zoologists and Physiologists should turn their attention to a phænomenon in the history of the reproduction of animals, which, during the last few years, has warmly interested the Apiarians and set them in the greatest excitement,-I mean the mode in which each separate colony of Bees contrives that the worker-, drone-, and royal-cells prepared by it are always furnished with the proper eggs, from which, as is required by the arrangement of these different kinds of cells, the worker-larvæ, drone-larvæ, and queen-larvæ destined to dwell in them, are always excluded. Hence the oviposition in the Bee-hive must be effected according to peculiar rules, in order that the conditions just mentioned may be fulfilled; this act of oviposition must be subjected to determinate laws, which do not affect the oviposition of most other insects, as in these it is a matter of indifference in what consecutive order and number male and female eggs are laid. But the question, how each separate Bee-colony succeeds in obtaining the suitable supply of eggrs for all its combs, differently as these are prepared as regards the number and arrangement of the three kinds of cells, has not been easily answered; nay, we may perhaps say, that this process bas hitherto appeared to be an impenetrable mystery, the solution of which has not been effected by the most careful endeavours and observations of the Apiarians continued for many years. This mysterious 
circumstance, which distinguishes the oviposition of the Bees, has also been the cause that, from time immemorial, the Apiarians have been disputing about the signification of almost every individual step in the process of reproduction in the Bees. This contest has continued even to the present day, and it is scarcely possible to imagine a single absurdity with regard to the history of the reproduction of the Bees, which has not already been expressed in sober earnest by some Apiarian, and is not to be read in print in one of the innumerable Bee-books. The greatest confusion especially was caused by the circumstance, that people could not agree with regard to the sexes of the Bees; the Drones were regarded as females and the Queens as males; sometimes it was supposed that the Workers alone had the care of the oviposition; sometimes the true act of copulation between the drones and the queen was supposed only to take place in the interior of the hive; the wedding-flight of the queen would then only be a sort of purification; whilst from another side it was asserted that the act of copulation was never performed in the hive, but always high up in the air during the wedding-flight. The act of coition was also entirely denied, the queen becoming fertilized by the mere agitation of her body during the weddingflight. I could fill many pages here with these contradictions, which are deposited in the annals of the history of Bee-life, and by which the study of this otherwise so interesting subject from books, has been stunted into a most ungrateful task.

This endless dispute about the reproduction of the Bees, often carried on with great animosity, in which the opponents of the different theories of generation relating to the Bees often showed themselves to be mere dilettanti, miserably furnished with natural-history information, was not fitted to attract the interest of physiologists ; indeed, it appeared as if the Apiarians wished to fight the battle out amongst themselves without foreign assistance, for the contest was never brought within the province of an earnest investigation of nature. Moreover, the naturalists could not very easily take part in the dispute, as they were mostly deficient in the practical knowledge of the aconomy of Bees, without which every attempt to settle the matter must have turned out imperfect, and would have been received with distrust by the obstinate Bee-masters, to 
whom such an attempt might have served as an instructive hint. In this dispute of the Apiarians, which was constantly blazing up afresh, the activity of the naturalists limited itself to their ascertaining and establishing as an incontestable truth, by the aid of the dissecting-knife and the microscope, that the drones are the male individuals, that the queen is the female individual, and that the workers are not merely asexual, but female individuals, the reproductive organs of which had not come to their full development. Upon this subject, investigations were made and published by the zootomists at very different periods. I refer only to the works of Swammerdam*, Réaumur†, Mademoiselle Jurine $\ddagger$, Suckow $\S$, and Ratzeburg $\|$. Although the representations of the male and female sexual organs of the Bees have been copied from Swammerdam's Biblia Naturce by various writers upon these insects, and consequently the facts established anatomically were communicated to the Apiarians, yet for a long time these truths could not boast of a recognition by all Bee-keepers. These entomotomic investigations probably did not appear sufficiently significant to the Apiarians, because there were still many things in the history of the reproduction of the Bees, which could not be explained with this knowledge of the sexual relations of these animals. Many practical Apiarians looked upon this anatomical proof of the sexes of Bees merely as theoretical stuff, and returned to their so-called practical way, which they imagined to be the right one, without regard to these facts, preferring to explain the different

* Bibel der Natur, 1752, pp. 188 \& 202, taf. 19 \& 21.

† Mémoires pour servir à l'Histoire des Insectes, tome v. 1741, pl. 32-34, which portion appeared in 1759 translated into German under the title of "Geschichte der Bienen."

† Vide Huber, Nouvelles observations sur les Abeilles, 2de édit. 1814, p. 431. pl. 11. fig. 1. In this work are deposited the interesting anatomical investigations of the above-mentioned laly, by whom the existence of abortive ovaries in the Worker-Bees was first ascertained; they are represented in an admirable figure prepared by herself.

§ Heusinger's Zeitschrift für Organische Physik, Band ii. Heft 3, 1828, p. 231. taf. 12. fig. 30 , taf. 14. fig. 38 .

|| Brandt und Ratzeburg, Medizin. Zoologie, 1833, p. 202. taf. 25. figs. 34,35, as well as Ratzeburg's Untersuchung des Geschlechtszustandes bei den sogenannten Neutris der Bienen und über die Verwandtschaft derselben mit den Königinnen, 1833, in the Nova Acta Physico-Medica, vol. xvi. pt. ii. p. 613. tal). 47. 
sexual functions in a perfectly arbitrary and unnatural fashion, according to their own individual and often very limited views.

After I had, in the year 1837, ascertained the existence and signification of the seminal receptacle in female insects*, and in 1843 called attention to this reservoir of semen in the QueenBees $t$, by the functions of which many phænomena in the reproductive activity of the Bees, which had hitherto remained problematical, or had been incorrectly explained, might be properly conceived, these investigations exerted no particular influence upon the perverted views of most of the Apiarians. They probably paid no further attention to them, as theoretical stuff, and yet, by the recognition of the function of the seminal receptacle, a phænomenon in the Bee-hive, which had been a source of wonder from time immemorial, could now be correctly explained. Thus, it had been ascertained by me, that after copulation had taken place, the semen of the drone, which filled the seminal receptacle to overflowing, remained in this place, capable of impregnating the eggs, not merely for months, but for years, as might be seen from the movements of the spermatozoids of this semen continuing for that period $\neq$. This explains how a queen, fertilized by a single coitus, after discharging her eggs in the first year, may again, in the following year, and even still more frequently, lay eggs capable of development, such as the hive requires, as fertilizing semen is still constantly preserved in her seminal receptacle, to fecundate eggs even for so long a period. But even this discovery was ignored by most of the Apiarians; as a general rule, fresh scruples as to the value of such anatomical and microscopical investigations were constantly rising amongst them, with respect to the determination of the sexual functions of the Bees.

There were two phænomena especially in the œconomy of the Bees, which troubled the minds of the Apiarians with reference to the division of the sexual functions in those insects,-I mean, 1. the capability of an imperfect-winged female to produce brood, and 2. the production of brond in a queenless

* See my Observations upon the Spermatozoa in feeundated female Insects, in Müller's Archiv, 1837, p. 417.

† Ueber das Receptaculum seminis der Hymenopteren-Weibchen, in Germar's Zeitschrift für die Entomologie, Bd. iv. 1843, p. 371.

+ See Germar's Zeitschr. loc. cit. p. 374 (with regard to Apis mellifica), and Wiegmann's Archiv, 1839, i. p. 107 (Vespa rufa). 
hive. Those who acknowledged the Queen as the female individual of the Bees, and, in accordance with the physiological laws hitherto current, ascribed to her the property of laying eggs capable of development only after previous copulation and the filling of the seminal receptacle with spermatozoids, were, in consequence of the first-mentioned phænomenon, rendered doubtful where and when the copulation of the Queen-Bee is effected. From this arose the dispute, so abundantly battled out in the books and journals relating to Bees, as to whether the Queen copulates in or out of the hive. That the former was possible was thought to be proved by the imperfect-winged Queens laying eggs capable of development, and thus the two sexes of Bees were supposed to perform the act of copulation in the interior of the Bee-hive, although such a copulation in the hive had never been seen. In this respect the Bees shared the same fate with the Roes; in these animals the practical gamekeeper could not comprehend why, after the single rutting time (in August and September), the uterus of the Roe contained no embryo, and therefore incorrectly ascribed a second rutting time (in December) to the Roes, although no one had met with Roes in copulation during that period. In those cases in which the second remarkable phænomenon previously mentioned occurred, namely, brood in a queenless Bee-hive, we should entirely mistake the sexual functions of the Bees. Such observations were principally employed in raising objections of insufficiency and untenability against the scientific endeavours at the determination of the sexes of Bees.

In most Zoological or Entomological works we find all these acrimonious controversies regarding Bee-life, either imperfectly mentioned or scarcely indicated, and hence it may have happened, that the history of the reproduction of the Bees has remained untouched by those physiologists who have specially occupied themselves with the generation of animals*. On this side no one had any idea what difficult problems are here presented to science for solution. Moreover the physiologists were lately engaged by another very attractive but also very difficult

* In the ample article upon Propagation (Zeugung) by R. Leuckart (sec R. Wagner's Handwörterbuch der Physiologie, Bd. iv. 1853), the remarkable history of reproduction in the Bees is searcely touched. 
subject, which incited them to inquire after the laws, according to which the asexual reproduction, previously regarded as an exception and now characterized by the name of Alternation of Generation, occurs disseminated amongst the lower animals, together with sexual generation.

By the entomologists the physiology of reproduction has been very scantily enriched of late, as most of them found their task only in rectifying the species of Insects; many of them endeavoured, at the expense of much time and trouble, to determine those species which have been furnished with names by Linnæus and Fabricius, whilst the majority found a still greater pleasure in enriching the systematic catalogues of Insects with a few perfectly new, although extremely insignificant species.

As up to a very recent period the Apiarians formed a sort of close corporation, wishing to answer the most important questions relating to the reproduction of the Bees amongst themselves, it may thus have happened that the fruits with which the knowledge of the history of reproduction was enriched by the labours of modern naturalists, could not be perceived at all by this close and short-sighted circle, and consequently could not be made use of by them. Nor did any voice ever force its way out of their circle which might have called in the assistance of the physiologists in the decision of certain problems in the reproduction of the Bees. Only within the last three years has the demeanour of the Apiarians changed in a most satisfactory way, and it must be said, in praise of the present circle of Apiarians, that at this moment it numbers amongst its members, men who have arrived at a conviction that Bee-life does not merely serve to furnish man with wax, honey and mead, but that it constitutes an extremely remarkable link in the great and most multifariously composed chain of animal existence, the importance of which, however, can only be understood by the assistance of knowledge such as is furnished by the present development of the Natural Sciences. By the activity of these enlightened men a complete revolution has taken place in Bee-keeping; a rational process introduced by the Apiarians, and rewarded by the richest results, now celebrates the most complete triumph over empiricism, and in this the names of Dzierzon and Berlepsch above all deserve to be named as conquerors. 
I believe I ought to give some information as to the way in which I have been induced to take part in this active movement of the Apiarians, as reference is made hereafter to a new theory of reproduction applying to the Bees, the defence of which I have undertaken, not however from a preconceived opinion forced upon me from without, but from an internal conviction springing from the course of my own investigations and observations. From the following pages the reader will understand how the investigation of the history of reproduction in Insects necessarily led me to the natural history of the Bees.

Probably within the last few years no branch of the history of animals has been enriched by new discoveries, and the amplification and completion of old observations, in so high a degree as the theory of animal reproduction. A mass of facts which were in direct contradiction to the theoretical laws so long established as the rules for the propagation of animals, and which previously had scarcely any value but their curiosity, have been united by the piercing eye of Steenstrup under the name of Alternation of Generations* to form a law, which is now found by naturalists to prevail in all directions. There was previously a long series of remarkable observations, against the correctness of which, as they stood in contradiction to the laws of reproduction previously adopted as the rule, doubts might willingly have been raised, if the stamp of truth had not been impressed upon them by the credibility of their observers. From many of these observations, over which a naturalist here and there was every now and then shaking his head in incredulity $t$, all doubt has been now cleared away by the recognition

* Steenstrup, Ueber den Generationswechsel, Copenhagen, 1842.

$\uparrow$ This negation of the processes connected with the alternation of generations is expressed even in the most recent times, in the views by which Ehrenberg and Diesing explain the nature of the Cercarice. Although direct observations and the most careful investigations have shown that these remarkable asexual creatures are not perfect animals, but belong, as larra, in the developmental series of certain Trematode worms, Ehrenberg sticks steadfastly to his opinion, that the Cercaric only present a distant similarity to the Trematoda (see the Bericht über die zur Bekanntmachung geeigneten Verhandlungen der Akad. der Wiss. zu Berlin a. d. J. 1851, p. 7;6), and reproaches Steenstrup with having allowed himself to be misled into the 
of the alternation of generations. Other observations which still remain problematical, the results of which also will not accord with the fundamental laws of the history of reproduction as at present known, will probably, as we must hope, be hereafter lighted up by the rays of the alternation of generations. Nevertheless from my own investigations I have also come to the conviction, that on the other hand we must not expect too much from the alternation of generations, as when we wish and imagine it, we do not always obtain an explanation from it. I must give especial warning against following an investigation too far with the preconceived notion that we have to do with an alternation of generations, as otherwise we may be led widely astray upon a false course, and never find the right way.

Not to deviate too far from the object which I have set before me in these pages, I will only here give prominence to that in the history of Insects which people have been induced to regard as a peculiarity of the alternation of generations,-I mean the remarkable reproduction of the Aphides; this, after standing so long as something quite abnormal and inexplicable, has now found its complete explanation in the nature of the alternation of generations. It is well known that in the Aphides, a sexual generation, represented by separate males and females, is followed by a series of generations, only including a single form, which proceed from each other in manifold repetition without any previous copulation, until after about seven to eleven such generations, a generation of males and females again makes its appearance. Steenstrup* regarded these forms of Aphides, which are capable of reproduction without the influence of the male gene-

important error of supposing that the Cercarice became developed into Distoma by casting off their tails. Ehrenberg at the same time refers to his exposition, description and figure of the Cercaria Ephemera, given in the year 1828 (Symbola Physica, Phytozoa Entozoa), which to his regret has not been referred to by Steenstrup, and which would probably have preserved him from some errors. In this description, however, Ehrenberg has declared the excretory organ representing a primordial kidney to be ovaries, and its coarsely granular contents, eggs, to which I have long since called attention (see my Lehrbuch der vergleichenden Anatomie der Wirbellosen, p. 139). Diesing, no less consistently, holds fast by the belief that the Cercarice are an independent and closed group of animals (sec his Revision der Cercarien, in the number for March 1855 of the Sitzungsberichte der Akad. der W'iss. in Wien).

* Op. cit. supra, p. 121. 
rative organs, and which had previously been looked upon as virgin female Aphides, as Nurses (Ammen), and consequently as those members of an animal-species subjected to an alternation of generations, which are capable of producing young in the asexual (or larval) state. Those Aphides which bring forth living young without a preliminary copulation, are in reality quite different in their organization from the true female Aphides, which lay eggs capable of development after the act of copulation. In the viviparous Aphides those organs especially from which the living young are produced, have quite a different form and organization from the sexual organs of the oviparous female Aphides, so that, in opposition to the ovaries (Eierstöcke), the products of which (eggs) only become capable of development by the action of the male semen, we may with perfect justice indicate these organs as germ-stocks (Keimstöcke), which are capable of producing young of themselves, without the influence of male fertilizing organs. These nurse-like, viviparous Aphides therefore, which instead of ovaries bear germ-stocks in their interior, are also destitute of the seminal receptacle, which occurs universally in the females of Insects and plays an important part in the act of fecundating the eggs*. Before the alternation of generations had yet beer introduced into science by Steenstrup. I had already called attention to the different conditions of organization in the oviparous and viviparous Aphides, and especially to the absence of the seminal receptacle in the lattert. Subsequently the development of the Aphides without fecundation has been completely explained by V. Carus $\ddagger$ as a process of the alternation of generations. The representation which Carus has given of the development of germinal bodies in the germ-stocks of the viviparous Aphides, has certainly met with a refutation from Leydig §, against which I have nothing to object; nevertheless, although, according to Leydig, the young are developed from the germ-bodies of the viviparous Aphides exactly as from eggs, by cell-formation, I would retain the denominations "germ-

* See my Observations on the Spermatozoa in fertilized female Insects. Müller's Archiv, 1837, p. 392.

$\dagger$ See Froriep's Nene Notizen, Bd. xii. 1839, p. 308.

¥Zur näheren Kenntniss des Generationswechsels, 1849, p. 20.

$\S$ Bemerkungen über die Entwickelung der Blattläuse in Siebold und Kölliker's Zeitschrift für wissenschaftliche Zoologie, 1850, p. (i2. 
body" and "germ-stock" for these reproductive organs of the viviparous Aphides, in order to distinguish them, on account of their different physiological import, with regard to the alternation of generations, from the eggs and ovaries of the oviparous female Aphides.

Owen* has regarded the asexual viviparous Aphides as virgin females capable of reproduction; but these viviparous Aphides indicated by Owen as virgin parents are certainly something very different from the oviparous Aphides in their virgin state before copulation. For the same reason also I cannot approve of Owen's expression Parthenogenesis, as applied by him to the alternation of generations, as under the term Parthenogenesis I do not understand reproduction by asexual nurse-like or larval creatures, but a reproduction by actual females, that is to say, by individuals furnished with perfectly developed, virgin female organs, which produce eggs capable of development without previous copulation and in an unfecundated condition.

* On Parthenogenesis, or the successive production of procreating individuals from a single ovum. London, 1849, pp. 30, 60, \& 76 .

[By reference to this work, it will be seen that, in the description of the parthenogenesis of the Aphides, the viviparous individuals are called 'larvæ,' and the basis or blastema of the virgin-progeny 'germ-masses': both are expressly distinguished from the true ova and oviparous females.

"The facts are briefly these:-

" The impregnated ova of the Aphis are deposited at the close of summer, in the axils of the leaves either of the plant infested by the species or of some neighbouring plant, and the ova, retaining their latent life through the winter, are hatched by the returning warmth of spring: a wingless hexapod larva is the result of the development. This larva, if circumstances, such as warmth and food, be favourable, will produce a brood, and indeed a succession of broods of eight larva, like itself, without any connection with the male. In fact, no winged males at this season have appeared. If the virgin progeny be also kept from any access to the male, each will again produce a brood of the same number of Aphides; and carefully prosecuted experiments have shown that this procreation from a virgin mother will continue to the seventh, the ninth, or the eleventh generation, before the spermatic virtue of the ancestral coitus has been exhausted. When it is so exhausted, a greater proportion of the nuclear germ-masses retained by the last procreant larvæ is used up: individual growth and development proceed further than in the parent : some members of the last larval brood are metamorphosed into winged males, others into oviparous females. By these the ova are developed, impregnated, and oviposited."-Owen's 'Parthenogenesis,' p. 23.] 
This last mode of reproduction has been denominated Lucina sine concubitu by the older naturalists, a term, which must not be applied, as has been done by Owen, to the alternation of generations, the reproduction taking place in this case under totally different conditions, namely by division, by gemmation, or by germ-bodies, which are not to be confounded with eggs, as in all these modes of propagation the immediate influence of the male fertilizing elements is wanting, and this has not been accidentally or abnormally omitted, but, as is proved by the whole course of development of these generations, remains out of action in accordance with certain laws.

As, with reference to my subsequent statements, I must lay a particular stress upon the distinction between the Alternation of Generations and Parthenogenesis, I repeat once more, that the viviparous Aphides are not virgin females which produce eggs capable of development without copulation, but that they are asexual, nurse-like or larval individuals, furnished with germstocks, which are as different as possible from the true virgin female Aphides*.

* [The author of the term 'parthenogenesis,' which was devised to replace a phrase both cumbrous and incorrect, or at best only partially agreeing with the phænomena referred to in the text, believed it to be, etymologically, applicable to the male as well as the female, or the neuter. $\delta$ tap $\theta$ '́vos is 'a young unmarried man,' just as i $\pi a \rho \theta$ évos is 'a maid': $\pi a \rho \theta \epsilon \nu \epsilon i a$, 'virginity, purity,' is predicable of either sex, or of a generative individual of no sex. The term 'parthenogenesis' was by no means proposed, as Siebold seems to imagine, under the idea that the virgin procreative $A_{p}$ his was a perfect female, and its brood produced from eggs. Previously to the appearance of the book so entitled, Professor Owen had published the results of observations showing that the virgin Aphides developed their brood from nucleated cells, forming 'germ-masses,' not from eggs (Lectures on Invertebrata, 1843); and the difference between the larviparous virgin and the oviparous wife in the Aphis tribe is given in detail. He defines 'parthenogenesis' to mean 'procreation, without the immediate influence of the male,' as, e.g., spontaneous fission, gemmation, development from germ-cells and germ-masses, or from unimpregnated ova. Should physiologists prefer, however, to limit the term as proposed by Professor Siebold, they will probably concur in the desirability of some other single word as an equivalent to 'Alternation of Generations.' $13 \mathrm{y}$ 'metagenesis' is meant the sum of those changes which certain species undergo in the progress, through suecessive indiviluals, from the ovim to the perfect impregnating and egg-producing form.] 


\section{ELUCIDATION OF THE CASES HITHERTO DESCRIBED AS PARTHENOGENESIS.}

Since the remarkable reproductive history of the Aphides must be transferred into the domain of the Alternation of Generations, it becomes a question whether we are not acquainted with other facts in the history of Insects, which are to be regarded as Lucina sine concubitu or Parthenogenesis. In point of fact, observations have been published by the most different Entomologists of old and modern times, which should lead us to infer the pretty widely diffused existence of a true Parthenogenesis amongst Insects. But all these narratives of female Bombyces and other moths, which, when kept isolated and without any copulation, laid eggs from which young were afterwards excluded, require a more exact investigation; for before we allow an important physiological law, derived from multifarious observations, to be thrown down by such statements, it is necessary to determine, whether we can put implicit faith in these narratives, whether we have to do here with credible facts, or whether, in this case, a fact has not been rather concluded from superficial, unsatisfactory and scanty observations, than positively proved. I have already indicated these cases*, as being such as to require an exact investigation, to get rid of every doubt as to the assertion that a spontaneous evolution of brood can really take place in the eggs laid by virgin female insects. I had at that time proposed to myself to submit the cases brought forward by so many naturalists and narrated again and again, by which the existence of a Lucina sine concubitu was to be proved, to a careful criticism. This criticism I will now undertake, in order to show how little of all these assertions remains admissible; for as we have to do with the maintenance or abolition of a physiological theoretical law, the importance of which has long been recognized, it follows as a matter of course, that none but

* See Zeitschrift für wissenschaftliche Zoologie, 1849, p. 97.

\section{H. HILL LIBRARY}


perfectly credible observations and such as exclude all doubt can be admitted as of sufficient weight to abolish the law :- that true eggs (produced in an ovary) cannot become developed into an embryo, until they have first been exposed to the fertilizing influence of the male semen (produced in testes).

The oldest communication relative to the reproduction of female insects sine concubitu, and one which has been repeatedly quoted, is due to the surgeon J. P. Albrecht of Hildesheim, who, in the year $170 \mathrm{~L}$, sent in to the Leopoldine Academy of Naturalists, a memoir with the title* "De Insectorum ovis sine pravia maris cum fœmella conjunctione nihilominus nonnunquam fœcundis." In this memoir Albrecht relates that he took a brown pupa, which had spun itself up on a black-currant bush, and preserved it under a glass in his summer-house, to see what moth would be evolved from it. At the end of July a moth of a yellowish-white colour escaped from it; this is not more particularly described, but as Albrecht has compared it with the Moth figured by Gödart in his Metamorphosis et Historia Insectorum (Pars I.) on tab. 33, we may suppose that it was either a Bombyx or a Noctua. This moth in a few days laid a great number of eggs and then died. Upon this Albrecht has the following remark:"Cum masculum huic papilioni haud adfuisse certus essem et propterea ejus ova subventanea et sterilia esse judicarem, vix amplius eorum habui rationem, relictis interim iisdem oscitantius et sine omni cura sub dicto vitro per totum tempus hyemale." It was only in April of the following year that Albrecht again looked after the glass, and was astonished at finding young black caterpillars in it instead of the eggs. As Albrecht has given no exact description, either of the nature of the glass, or of the mode in which it was closed, and did not watch either the glass or its contents with the necessary care, it does not appear from this case, whether the openings of the glass in which the moth was kept were closed in such a manner that no male moth of the same species could have found admittance and an opportunity of copulating with the enclosed female. The same surgeon also mentions a Spider, which had been in the possession of Dr. St. Blancard, and which for four consecutive years laid eggs

* See Miscellanea curiosa sive Ephemeridum Academia Casar. Leopold. Natur. Curios. Dec. iii. Annus ix. \& x. 1706, p. 26. 
from which young Spiders escaped, although no male Spider had ever appeared in the business*. This short communication gives us not the smallest information upon the question, whether this fertile Spider was actually taken in the virgin state, and whether her seminal receptacle may not have been filled with semen, before her capture, by a male Spider. Precisely the same remarks will apply to that female Spider which Dumeril saw in Audebert's possessiont, and which produced brood for two years when imprisoned, without the assistance of a male. That the male semen preserved in the seminal receptacle of the female insect retains its fertilizing power for years, is an ascertained fact; we know, for example, of Queen-Bees, that after a single copulation they may be fertile for four or five years; and upon this point I may appeal to the testimony of the Pastor of Carlsmarkt in Silesia, M. Dzierzon $\ddagger$, whom I have learnt to know and value as one of the most experienced and credible Bee-keepers, amongst.living Apiarians. Another observation of spontaneous reproduction sine concubitu, made by Basler upon a female of Gastropacha quercifolia bred from the caterpillar, is very briefly communicated by Bernoulli $\S$. As in this case we neither find any mention of how long it was after the exclusion of the moth before Basler found it, nor any account of the secure preservation and shutting up of the pupa, a number of objections may be raised against the supposed Parthenogenesis in this case, on the ground of the deficiency of all exact details. No less inadmissible appears the case observed and communicated by Bernoulli himself as one of Parthenogenesis \|. He had allowed a caterpillar of Episema caruleocephala to change to the pupa state, but afterwards left the pupa in a box without paying any further attention to it; in about fifteen days he opened the box for the first time, and was surprised to find in it, besides the excluded moth which

* This observation was first communicated in the Miscellanea curiosa, Dec. iii. Annus iii. 1696, p. 63.

† See Dictionnaire des Sciences Naturelles, tom. ii. 1816, p. 324.

* See his Theorie und Praxis des neuen Bienenfreundes, 2 Aufl. 1849, pp. $104 \& 111$.

\$ Sce Nouveaux Mémoires de l'Académie Royale des Sciences et BellesLettres, Année 1772. Berlin, 1774, pp. 24 \& 34.

\| Op. cit. supra, p. 25. 
was dead, a family of young caterpillars which had already devoured the pupa-case of their mother and a portion of their own egg-shells. The untenability of the assertion that, in the cases just mentioned, a Lucina sine concubitu took place, has already been proved with such convincing reasons by the Theresian professors (Denis and Schiffermüller), that I cannot do better than appeal to the arguments which the learned Viennesc entomologists carried out in the following words*:-

"We have too often observed that males have found their way to females which had been excluded in our rooms, and were perhaps even stuck upon a pin, and copulated with them, when we did not at all expect it, and frequently only observed it accidentally and late, and we have hardly observed this more with any species than with the very two species of Bombyces (in our catalogue, Fam. J. No. 1 and B. No. 1 †) which according to the naturalists above mentioned laid fertile eggs without copulation; of the latter species indeed, we have frequently exposed a female designedly in the evening at the open window, in order to take males, which our friends required, and generally with the desired result. The narratives even of both the learned men appear to us not quite to exclude such an unperceived accident, or an accidental confusion or mistake. Herr Basler did not imprison the pupa but the excluded female in a glass (certainly as soon as he observed it), and left the eggs lying uncared for, upon a stone, until November; moreover he did not rear the young caterpillars; and Herr Bernoulli let the pupa with the box go out of his sight until he found caterpillars already in it. Lastly, these very two species have often been reared by Réaumur, Rösel and other naturalists, and in very considerable numbers by ourselves; and would they not once have asserted their power of propagating without copulation, if they really possessed it? and yet, the females which did not copulate, never laicl anything but barren eggs." Pastor von Scheven also has, with great tact, weakened the statements of Basler and Bernoulli, as proofs of the occurrence of a Lucina sine concubitu, by the

* See Systematisches Verzeichniss der Schmetterlinge der Wiener Gegend, herausgegeben von einigen Lehrern am K. K. Theresianum, 1776, p. 293.

+ The Theresian Professors mean hereby Gastropacha quercifolia and $S a-$ turnia pyri. 
following objections *:-_" Even the most learned naturalist, often without noticing it himself, comes to the false conclusion: I have not observed this or that, therefore it has not taken place. Herr Basler's moth, as the narrative itself shows, was not of sufficient importance to him for exact observation, until he had recognized it as a hermaphrodite, by the supposed wonderful issue. But who is to give us security that a copulation and fecundation did not previously take place? In all probability Herr Basler only reared a single moth of this species, from which he came to the conclusion that no copulation had been possible. But how easily it may have happened that a copulation nevertheless took place without his knowledge, the following observations which I had the opportunity of making some years ago upon the Phal.Quercus, Linn., may distinctly show. Of this moth, I also had only a single caterpillar, which is figured by Rösel in the first part of his Insecten-Belustigungen, tab. $35 a$, and obtained from it a female moth. But as this came out of its cocoon just in the evening, I allowed it to creep up to the top of a window in my room, so that it might expand its wings properly, and as it behaved quietly, I allowed it to remain there through the night. The next day I perceived a male of this moth in the corner of the room, at which I was greatly astonished, as I knew with certainty that I had not had more than a single caterpillar of this moth in my house. However, I had not to wait very long for the solution of the riddle. For soon afterwards, thinking I heard a tapping at the window several times repeated, and opening the window to discover the cause of it, I soon perceived that several moths were flying about before it; and although, from their rapid flight, I did not at once recognize them for what they were, I concluded from their strong flight, which they occasionally directed straight against the window, that they had something to seek there. I consequently did not allow them to knock long in vain, but opened some windows for them, upon which several males of this moth soon came into my room, and quickly discovering the female endeavoured to copulate with her. This history not only shows how strong is the scent of the male moths of this species and how great is their copulative

* Beiträge zur Naturgeschichte der Insekten. Naturforscher, Stuck 20, 1784 , p. 50 . 
impulse, but it also leads us to suppose that the same thing may have befallen Herr Basler, whose moth belongs to the same class with ours, and is closely allied to it in its nature and mode of life. For if the first male which found its way into my room, and which, no doubt, had slipped in through a small opening in the window, had immediately copulated with the female, and afterwards concealed itself in a corner of the room, or flown away again, and the following day had not been so fine, so as to give the opportunity for the above observations, I should have obtained fertilized eggs from my moth, in exactly the same way as Herr Basler, without thinking that a fecundation had taken place, and perhaps without thinking an error possible." Bernoulli's observation also is cleared up by Von Scheven with such weighty objections, that every trace of credibility is entirely wiped out of it. As Scheven has treated the subject with that felicity of expression peculiar to his time, it would require too much space if I were to reproduce his polemics in their full extent; I shall therefore only quote the most important part of his observations. Amongst other things in Bernoulli's relation it had struck Scheven, that in fifteen days after the spinning up of the caterpillar the little caterpillars had already escaped from the eggs, for which reason he expresses himself upon this point as follows*: "In the ordinary course of nature the caterpillar takes some days before it becomes converted into a pupa in its cocoon. The pupa usually lies at least fourteen days, and for the most part still longer, in its cocoon, before the moth makes its appearance from it. But still more time is required, before the young caterpillars come to maturity in their egg's and creep out of them. The greater or less warmth of the season, or of the place where the pupæ and eggs are kept, certainly often gives rise to a change in the duration of the time appointed for these events. But that all these changes should occur within fourteen days, is just as incredible as that a maiden, who has never seen a man in her life, and for still greater security has gone into a nunnery, can give birth to a child there, in an innocent way, within fourteen weeks. In all probability another female moth, which the author may have had long previously in this box, and 
which may even have been of a different species (for the observer does not appear to have carefully examined the young caterpillars, which indeed are not easily known in their youth), had laid her eggs in one of the corners of the box, which the possessor had forgotten, or never observed. From these the young caterpillars probably made their appearance, just at the time when the Phal. pacta* laid her unfertilized eggs; from want of nourishment they devoured the still fresh and soft eggs, and finally fell upon the pupa, or rather the pupa-case. This or some other mistake, of which many may be imagined, may have happened; but this much is certain, that the history even in the way in which it is related and explained, deserves no credit, and that the conclusions built upon it must be proportionably incorrect."

I could not refrain from reproducing the objections which Scheven urged against the observations published by Bernoulli, literally, as far as space would permit, as they have hitherto remained quite unnoticed; for as often as it was asserted that certain insects could lay eggs capable of development without previous impregnation, reference was always made, even in the most recent timest, to the observations published by Bernoulli, which however had long before been invalidated as inadmissible by Scheven.

Just as little value attaches to the other statements which are supposed to serve as vouchers for the existence of a Lucina sine concubitu, as, being in the form of very short notices, they also offer not the slightest security as to what precautions, if any, were taken to avoid the mistakes which so easily slip into such observations. For this reason we can attach no weight to the case which Suckow has communicated without any further

* For what reason Scheven indicates the moth upon which Bernoulli made his supposed observation upon spontaneous reproduction as Phal. pacta, I do not know, for Bernoulli compares his motlı with the Noctua figured by Rösel in his Insectenbelustigungen, iv. Sammlung, No. 15, which is nothing but Episema caruleocephala.

† With regard to this compare G. R. Treviranus (Biologie, Band iii. 1805, p. 265) ; Burmeister (Handbuch der Entomologie, Band i. 1832, p. 337); Lacordaire (Introduction à l'étude de l'Entomologie, tom. ii. 1838, p. 383); and V. Carus (Zur näheren Kenntniss des Generationswechsels, 1849, p. 21). 
particulars in the following words*:- "I have reared females of Bombyx Pini, which, without any previous copulation, laid eggs from which the caterpillars were developed, and passed through all their transformations." Another case was mentioned by L. C. Treviranus in these wordst:- "I have myself been an eye-witness, that a female of Sphinx Ligustri, which had been developed from the pupa in my room during the night, and was impaled upon a pin the next morning, laid numerous eggs on the second day, from which caterpillars were evoived, exactly in the same way as if a copulation with a male had taken place, which most certainly was not the case." But when we remember what is stated above by the Theresians and Scheven, Treviranus' simple assurance, that in the case of this female Sphinx no copulation took place, will not suffice to remove all doubts as to whether a male may not have come secretly and unobserved and effected a copulation with this female, which might have escaped the observation of Treviranus the more easily as he certainly did not previously think of a Parthenogenesis, or watch the impaled female very closely. Still more unsatisfactory are the very short statements of Burmeister $\ddagger$, in which nothing further is said than that Dr. Al. von Nordmann observed a spontaneous development not long before in Smerinthus Populi, and that a similar instance was known in Gastropacha potatoria. Lacordaire's statements $\S$ also, regarding Lucina sine concubitu in Gastropacha Pini, and a case observed by Carlier, according to whom three generations were produced from a specimen of Liparis dispar without copulation, can only be received with distrust, as we look in vain in them for any exact description of the employment of any of those precautions which are necessary in such observations.

Another case of Parthenogenesis is said to have been observed by Plieninger $\|$. He had reared several females of Gastropacha

* See Heusinger's Zeitschrift für die organische Physik, Band ii. 1828, p. 263.

† See his Vermischte Schriften anatomischen und physiologischen Inhalts, Band iv. 1821, p. 106.

$\ddagger$ Handbuch der Entomologie, Band i. p. 337 .

§ Introduction, tom. ii. p. 383.

\| See Würtembergische naturwissenschaftliche Jahreshefte, Heft i. 184R, or Schleiden und Froriep's Notizen ans dem Gebiete der Natur- und Heilkunde, Band vii. 1848, p. 232. 
Quercus from the caterpillars, and pinned them immediately after their exclusion. These deposited their eggs whilst impaled upon the pins, and of these a great part were fertile, although in this case, as Plieninger asserts, no fecundation had taken place. $\mathrm{He}$ adds that the fertile eggs were distinguished from the barren ones by their not collapsing like the latter, but retaining their convexity until the exclusion of the young caterpillars. Whether Plieninger actually watched for and saw the young caterpillars quit their eggs, has not been mentioned. But even if we suppose that the exclusion of the caterpillars really took place in the present case, this phænomenon will certainly have come unexpectedly upon Plieninger, and he will have omitted to guard the impaled females with the necessary care, until the act of oviposition, against the access of males.

I must still refer to two cases which have commonly been cited as evidence of a Lucina sine concubitu, but which upon closer examination have nothing whatever to do with our question.

One of these cases relates to the Bombyx, Orgyia gonostigma, the apterous female of which, Gödart reared from the caterpillar* and saw it lay fertile eggs without copulation, a statement which not only astonished Gödart, but also Lister $†$ and Goeze $\ddagger$. But Swammerdam $\S$ and Réaumur\| have already stripped all the marvellous from this relation, by showing that Gödart had not recognized the winged individuals of this species as the males belonging to this moth, so that, without suspecting it, he had at the same time reared the males of the species, which very probably might have given occasion to a copulation with this female un-

* See Metamorph. et Hist. Nat., pars secunda, de Insectis, 1662, p. 106. Experim. xxx.

$\dagger J$. Goedartius, de Insectis cum notularum additione. Opera Lister. 1685, No. 78 b. p. 190.

‡ See his Entomologische Beiträge, Band iii. Th. iii. 1781, p. 9. I must, however, remark here, that Goeze has incorrectly quoted from Lister (Gödart) No. $78 a$ and $b$ to Bombyx antiqua, instead of No. 79. In a copy of Gödart's Metamorphosis with coloured figures, which I have now before me, it is perfectly clear that the moths and caterpillars copied from it in Lister's edition, Nos. $78 a$ and $b$, belong to Orgyia gonostigma, and No. 79 to Orgyia antiqua.

$\S$ See Biblia Natura, 1752, pp. 15 \& 227.

\|I See Mémoires pour servir à l'Histoire des Insectes, tom. i. part. i. 1737, 12mo, p. 409. 
perceived by him. The other case which is also usually reckoned as a proof of a Parthenogenesis, relates to the observations made by Pallas* upon Psyche graminella and Fumea nitidella, to which I shall hereafter pay a closer attention (p. 24). Those cases of Lucina sine concubitu which are supposed to have been observed in Bees and Gall-flies, are also passed over here, as I must subsequently subject them to a separate criticism.

If we glance once more over all the cases hitherto referred to, which were supposed to give evidence of a Parthenogenesis, the whole of them agree in that the soi-disant spontaneous evolution of the brood was noticed accidentally and unexpectedly by the observers, so that all those precautions which are necessary for the attainment of a certain observation fulfilling all the requirements of science, were entirely neglected. For this reason, therefore, we must doubt the correctness of the conscquences which the above-mentioned naturalists have derived from their observations, and the more so, as we can directly oppose to these observations, others which were made from the commencement with the view of obtaining a certainty with regard to the possibility of a spontaneous development of the unfertilized eggs of insects, and which, with the employment of all the necessary precautions, have only furnished negative results. As evidence of this I may cite the multifarious observations of Réaumur, Rösel, and the Theresians, who never obtained caterpillars from the eggs laid by unimpregnated female moths. Direct experiments in rearing caterpillars from the unimpregnated eggs of moths have been made by Keferstein $†$, according to his own statements, in which however he always came to a negative result. But there is an observation made by Blancard and Audebert upon Parthenogenesis in Spiders which may even be placed in opposition to the above-mentioned inadmissible observations, and this shows that the Spiders also are subjected to the general physiological laws in their reproduction. Blackwall $\ddagger$, namely,

* See Nova Acta Physico-medica Academia Natura Curiosorum, tom. iii. 1767, p. 430 : "Phalænarum biga, quarum alterius Femina artubus prorsus destituta, nuda atque vermiformis, alterius glabra quidem et impennis, attamen pedata est, utriusque vero, sine habito cum masculis commercio, foreunda ova parit."

+ See Entomologische Zeitung, 1842, p. 9().

† See Annals of Natural History, 1845, vol. xv. p. 227. 
reared several young females of Agelena labyrinthica, Teyenaria domestica and Tegenaria civilis in a perfectly isolated condition, and imprisoned in transparent glasses; when these, after years of care and feeding, had become full-grown, they laid eggs in their virgin state, from which no brood was evolved.

The negative results obtained by these direct observations of themselves furnished a sufficient ground for doubting the correctness of the cases of pretended Parthenogenesis above referred to; but the most convincing proof that observations of this kind in general, which are only made by accident, and not designedly contrived, must be received with the greatest distrust, as on such occasions mistakes so easily slip in, is furnished by the following epistolary communications. I am indebted to Herr W. von Langsdorff, of Lahr, for the following note:- " $\mathrm{A}$ female of Gastropacha Quercus was evolved, which I took out of the breeding-cage standing in my garden and carried into my cabinet, which lies behind two rooms, where I placed it in an open box; the doors stood half open, as it was the height of summer and very hot; when I returned some time afterwards, I found this female Bombyx in copulation with a male, which, however, flew away swiftly on my arrival; this female of course laid fertilized eggs, whilst other females of $G$. Quercus which were excluded soon afterwards, and which I had carefully imprisoned, certainly laid eggs, but these subsequently shrivelled up, as they were unimpregnated. Now, had I come a little later, when the male had already flown away, I should probably have been deceived also, as the female Bombyx was in exactly the same position as that in which I had placed it, and I could not have supposed that a male Oak moth could slip so unperceived through two rooms, in which there were several persons at the time, into a third." Herr von Heyden wrote me a little while ago: "It is remarkable, besides, with what acuteness certain male moths scent out their females. Many years ago I saw a number of males of Psyche pulla swarming about a closed window in my sitting-room, and some of them settling on the panes. My attention being attracted by this, I perceived that females of this species had been evolved in a box standing in the room near the window. I was acquainted with no locality for this species in the neighbourhood of my dwelling." How easily, even in this 
case, if the windows had been imperfectly closed, might a copulation of the female Psyche have been possible and yet have remained unobserved! What unexpected errors one may be exposed to in such observations, is also shown by a communication made by Lucas*, according to which a male and female moth were evolved from two pupæ of the silkworm enclosed in a common cocoon. It might be possible, if perchance both the moths in such a common cocoon quitted their pupa-cases simultaneously, that they might have copulated in the interior of the cocoon notwithstanding the narrow space; and if then the female alone had quitted the cocoon and laid eggs capable of development, how easily might the still-concealed male have been overlooked, and the case itself regarded as one of reproduction sine concubitu!

* See Annales de la Société Entomologique de France, tom. iii. 1845, p. lxxxii. 


\section{TRUE PARTHENOGENESIS IN SONE SAC-BEARING LEPIDOPTERA.}

From the statements previously published I was unable to convince myself, that the possibility of a true Parthenogenesis in the insect-world was established beyond all doubt. In what way the observations so constantly repeated of a Parthenogenesis in the Psychidee were to be received and explained, I have shown in a previous memoir in the Zeitschrift für wissenschaftliche Zoologie*. A mistake is the more possible in this case, as the excluded footless females of the genus Psyche copulate in the interior of their former caterpillar-sac, and after the performance of the copulation creep back again into the pupa-case, in order to store it with fecundated eggs. A fertilized female Psyche of this kind, which has retired completely into her pupa-case, has often been regarded as an unexcluded virgin individual, whose power of laying eggs capable of development could not but excite the astonishment of those who were unacquainted with the mode of Iife of the true Psyche, but could not in the least surprise any one who was familiar with these mysteries. The Sac-bearers which are separated from the true Psychides according to the modern system and referred to the genus Fumea, may also give rise to similar errors, as, although their females, which are furnished with six legs, do certainly quit the former caterpillar-sac after their exclusion, and await the males clinging firmly to the outside of the sac by means of their laying-tube, yet, after copulation has taken place, they stuff the pupa-case, which remains in the sac, so completely from top to bottom with eggs and wool from the extremity of their abdomen, that the full pupa-case, the cleft thorax of which is thus completely pressed together and consequently appears to be closed, may very easily be confounded with a still unexcluded pupa.

After I had called attention to these important facts in the

* Band i. 1849, p. 93, "On the Reproduction of Psyche." 
history of the Psychidce, I nevertheless received assurances from various Lepidopterologists that they had notwithstanding observed a Parthenogenesis in the Psychida, and felt certain that they had made no mistake. All the more exact statements referred to species of Sac-bearers, which are no longer considered as true Psychide, but are placed amongst the Tineide, as the genus Talceporia, or more properly Solenobia.

I felt myself incited by such communications to turn my most particular attention to these little Sac-bearers, which I had previously taken but little notice of, in which, being then in Freiburg, I had to congratulate myself on the assistance of Herr Reutti, a very able and credible Lepidopterologist. The two species, Solenobia lichenella, Linn. and Solenubia triquetrella, Fischer von Röslerstamm*, which are very abundant in the immediate vicinity of Freiburg, offered themselves to our observation, and of these, after my removal from Freiburg to Breslau, I found I was able to make use of many specimens at the latter place; in Berlin also I collected at two different times a great number of sacs of these two Solenobia, so that during the years 1850,1851 , and 1852, I got together several hundreds of these sacs, but to my greatest astonishment none but female individuals were excluded from these sacs $\dagger$, and only a single locality furnished me with a couple of males of Solenobia triquetrella.

I was enabled to observe that these virgin female Sac-bearers, which I constantly watched in little vessels closed with glasslids, clung firmly to the outside of their sacs, in the same fashion as the females of Fumea niiidella, and filled the sac with eggs by pushing in their laying-tubes; however, these female Solenobia differed from the female Fumea in this respect, that the former in escaping and creeping out dragged the pupa-case with them quite out of the sac. The pupa-case then remained

* In regard to the determination of these two species of Sac-bearers, I refer to Zeller's classical description of the genera of Tineacea, in the Linnaca Entomologica, Band vii. 1852, p. 343.

$\uparrow$ Wocke also collected about 600 sacs of Solenobia lichenella in the vicinity of Breslau, from which he did not obtain a single male. See the thirty-first Jahresbericht der Schlesischen Gesellschaft für vaterländische Cultur über das Jahr 1853, p. 182. 
at first sticking loosely into the posterior free opening of the sac, which was firmly spun down, but also frequently fell down, so that the female Solenobia always lay their eggs immediately in the sac itself. The females of the sac-bearing genus Taleporia, which approaches most closely to Solenobia, proceed in exactly the same way in escaping and laying their eggs.

But what particularly struck me in the behaviour of the female Solenobia, was the circumstance that they commence the business of oviposition very soon after their exclusion, whilst the females of Fumea put off their egg-laying until they have copulated, by which means many of the latter in my breeding-cages, in which there was sometimes a deficiency of males, died of vain expectation in their virgin state, without having previously discharged their eggs. The female Solenobia, on the contrary, possessed such a violent impulse to lay their eggs, that when I removed them from their sacs, they pushed their laying-tube about in search of the orifice of the sac, and at last let their eggs fall openly. If I had wondered at the zeal for oviposition in these husbandless Solenobia, how was I astonished when all the eggs of these females, of whose virgin state I was most positively convinced, gave birth to young caterpillars*, which looked about with the greatest assiduity in search of materials for the manufacture of little sacs!

After I had been first surprised by this phænomenon in the spring of the year 1850, I could not but be convinced that De Geer, Scriba, and Speyer, who reported that these animals laid fertile eggs without previous copulation, had not deceived themselves, as I previously supposed $†$; nevertheless, I could not persuade myself that this phænomenon was to be explained as Parthenogenesis, but rather thought I recognized in the whole phænomenon, an asexual propagation analogous to the reproduction of the Aphides, regarding the female Solenobice which had laid eggs capable of development without copulation as asexual nurses. In this way I quieted myself with the idea that an alternation of generations occurred in the insect-world, not

* This production of fertile eggs without previous copulation has also been ubserved in Solenobia lichenella by Wocke (op. cit. supra, p. 182) and Reutti (see Beiträge zur rheinischen Naturgeschichte, Heft 3, 1853, p. 176).

† See my memoir above referred to, on the Reproduction of Psyche, p. 99. 
only amongst the Aphides, but also amongst some moths*. Subsequently, however, the thought occurred to me, that by the careful dissection of these questionable Solenobia-nurses, a much greater anatomical difference ought to be exhibited between them and the females of Solenobia than between the Aphisnurses which produce living young and the egg-laying female Aphidest; for it is well known that all female Lepidoptera possess two sexual orifices, one behind the other, of which the extreme or hindmost one serves for the deposition of the eggs, whilst the second orifice, placed before this (anteriorly), has to receive the male generative organ during the act of copulation. If these moths which laid eggs capable of development were nurses, I expected, on examining them carefully, to find neither the second sexual orifice on the exterior, nor the copulative pouch (bursa copulatrix) and seminal receptacle in the interior, parts which I had previously found in all female Lepidoptera I was, however, quite deceived in my expectations, for all those Talaporia which had been at first regarded by me as nurses, proved, without exception, to be perfectly developed female moths; they all possessed the double sexual orifice, the copulative pouch, and seminal receptacle, arranged and developed in the same way as in other female Lepidoptera. The copulative pouch and seminal receptacle were always empty and unexpanded. Moreover no difference was discoverable (as to number, form and contents) between the ovaries of these supposed nurses and the same organs in other female Lepidoptera; in short, I convinced myself in the most positive manner, that in this case we had nothing to do with nurses, but with virgin females

After this discovery, the name of Parthenogenesis, which the English naturalist Owen applied to the alternation of generations, must be peculiarly the most suitable denomination for the

* See my Bemerkungen über Psychiden, in the Jahresbericht der Schlesischen Gesellschaft für vaterländische Cultur über das Jahr 1850, p.84; reprinted in the Entomol. Zeitung, 1851, p. 341, and in the Transactions of the Entomological Society of London, vol. i. 1851, p. 234.

† See Froriep's Neue Notizen, Bd. xii. loc. cit. supra.

\$ See Müller's Archiv, 1837, p. 417.

$\S$ I have already called attention to this fact at the meeting of German naturalists at Gotha, as appears from the short notice in the Tagblatt der 28ten Versammlung deutscher Naturforscher und Aerzte, No. 3. p. 28. 
reproductive process just described by me in Solenobia triquetrella and lichenella.

The two species of Sac-bearers just mentioned are not however the only representatives of the true Parthenogenesis; an equally striking example of the virgin reproduction of a female insect is presented by Psyche Helix. Of this extremely remarkable moth we are at present only certainly acquainted with the female. In the caterpillar state it lives in a sac, which in its form resembles a sinistral snail-shell, to which similarity the specific name given by me to this Psyche also refers.

The sac of Psyche Helix is nearly as large as a small pea (generally 2 lines Rhenish in height, and the same in breadth); it exhibits three and a half whorls (figs. 1-3), and consists of a firm whitish tissue, which is thickly and firmly coated externally with small particles of earth. The colour of the sac is usually earthy-grey, but in certain districts blackish or reddish-brown sacs occur; this is probably in connexion with the colour of the soil from which these Sac-bearers partly derive the material for their sacs. Here and there also individual cases occur with separate whorls (anfractibus devolutis). The uppermost and narrowest half-turn is always very indistinct, and generally appears collapsed. At the place where the second whorl commences there is always a lateral opening (figs. $2,3, \& 6 a$ ), the margins of which usually lie down and conceal the entrance to the cavity of the whorl*. When the caterpillar has evacu-

* Besides Psyche Helix, there are some other insects, whose larvæ, as casebearers, manufacture sacs in the form of a snail-shell. In the genus Psyche itself there occurs another species, the caterpillars of which, like those of Psyche Helix, bear about with them a spirally-twisted sac. By the kindness of Herr Zeller of Glogau and Dr. Rosenhauer of Erlangen, I possess two earth-coloured, snail-like sacs with perfectly flat convolutions (figs. 15-17). found in Sicily and Spain. They are nearly three times as large as the sacs of Psyche Helix, and from their different form and size belong to auother species, to which I will give the provisional name of Psyche Planorbis. Both sacs, like those of Psyche Helix, are covered with fine grains of earth and sand cemented on them. Behind the uppermost and narrowest half-turn there is also a lateral aperture, which is duc to an interruption in the walls of the sac taking place here (fig. 15 a). In the family of the Phryganidae also, larræ occur, which form a spirally-twisted domicile. The first notice of this was furnished by Shuttleworth (in the Mittheilungen der naturforschenden Gesellschaft in Bern, June 1843, p. 20), and as this is but little known, I will reproduce it 
ated its fæces, it pushes them out of this aperture, when the edges of the latter rise a little. This lateral opening of the sac

here literally. The passage in question runs as follows:- "Amongst the Mollusca collected by Blauner in Corsica, there was a considerable number of a shell, which was at first taken for an undescribed species of Valvata, and which appeared to be nearly allied, if not identical, with the Valvata arenifera of Lea (Observ. p. 114. tab. 15. figs. $36 a \& b$ ), from North America. The perfectly regular, spirally convoluted shell consists of a very fine transparent membrane, upon which very small grains of sand and stones are fixed with the greatest regularity. The circular orifice is closed by a very delicate, apparently spirally convoluted, membranous operculum. The general form, as well as the dimensions, remind one strikingly of the Valvata depressa, Pf. In all the individuals provided with an operculım, there was either the larva or the nympha of an insect, probably belonging to the genus Phryganea, which, bent into a half-spiral, lay singly in each shell. Under the microscope, the opercula exhibited, besides the spiral or regularly concentric structure above referred to, an excentric longitudinal opening running parallel to the inner margin. Specimens of the Valvata arenifera of Lea, which I have recently obtained from Vienna, exhibit precisely the same structure both of the shell and operculum. In Réaumur's Mémoires pour servir à l'Histoire des Insectes, tom. iii. p. 193. pl. 15. figs. 22-24, there is a short description and figure of a (spirally-convoluted) Phryganea-case (occurring in Switzerland). This species of Réaumur's, however, differs in every other particular from the species above described, and also appears to possess no operculum." The case last referred to by Shuttleworth belongs to Psyche Helix; the other one, which resembles a Valvata, on the contrary, is a very different thing (see my figures 18-22), and is certainly produced by a Phryganidous insect. I saw several of the habitations of this insect in Bremi's collection at Zurich, partly collected in Corsica and partly on the Lake of Como. Bremi has given the name of Helicopsyche Shuttleworthi to the questionable Phryganidan from which these spiral cases are derived; and many specimens of a similar smaller case have been since sent to him from a brook in Porto Rico, the inhabitant of which Bremi has named Helicopsyche minima. By the kindness of Ielr Bremi I have obtained several specimens of both kinds, which are essentially different in their structure from the sacs of Psyche Helix. As regards their size, the diameter of the largest sacs of Helicopsyche Shutlleworthi is 2 lines (Rhenish), and of those of H. minima 1 line. A principal distinction between these Phryganidan domiciles and the spiral sacs of Psyche consists in the fact, that whilst in the case of Psyche Helix extrcmely fine grains of sand are stuck as a coating upon the outer surface of the white web of the sac-walls, in Helicopsyche the walls of the habitation are formed directly and solely of larger, polygonal particles of sand, closely cemented together from within and without. The caterpillars of Psyche also never close their sacs with an operculum. But that the Helicopsyche-sacs are really produced by a Phryganidous insect, I ascertained from the contents which I extracterl from two cases of Helicopsyche minima 
is really due to an interruption, which the walls of the sac exhibit at this point in almost the whole of their transverse diameter. The body of the caterpillar is indeed also spirally curled (figs. 4 and 7), but in its form and length it only corresponds with the lowermost whorl of the sac. In this way it would be impossible for the caterpillar to push its body up into the uppermost narrow whorl for the evacuation of its fæces. The female of Psyche Helix, like all females of Psyche, after completing the business of oviposition, quits its sac, which is firmly spun down by its anterior aperture, and for this purpose it makes use of the lateral

still furnished with opercula. These consisted of a dried pupa, which in the form of the legs and of the long antennæ, the four hairy rudiments of wings, and the two biting jaws, exactly resembled a Phryganidan. The description given by Lea of his Valvata arenifera (in his Observations on Najades and Descriptions of new species, vid. Transactions of the American Philosophical Society, vol. iv. Philadelphia, 1834, p. 104. pl. 15. fig. $36 a$, b. See my copies, figs. 23, 24) runs as follows :-_" Testa orbiculata, convexa; anfractibus tribus, qui arenis agglutinatis operiuntur; umbilico lato ; spira obtusa. Hab. Cumberland River near Nashville. Length four-twentieths of an inch. Remarks.This very curious and interesting species was among the freshwater shells so disinterestedly sent to me by the Lyceum of Natural History of New York, to be examined and inserted in this paper. It has the singular property of strengthening its whorls by the agglutination of particles of sand, \&c., by which it is entirely covered, and in this character it resembles the Trochus agglutinans, Lam. (Trochus conchyliophorus, Authors). The apex, in all the specimens which I have had an opportunity of examining, is broken. The operculum was observed in two specimens sufficiently perfect to exhibit a striated horny structure."

The sacs of Helicopsyche minima communicated to me by Bremi, agree almost perfectly with this shell of Valvata arenifera described and figured by Lea. Even the bronze-green colour is common to both of them. The presence of an operculum is also in favour of the derivation of this habitation from a Phryganidous insect, as the Sac-bearers amongst the Lepidoptera form no operculum, but always spin down their sac by its lower aperture to foreign substances. Moreover, the opercula, of which I found several in my specimens of the sac of Helicopsyche minima, had also a striated appearance like those of Valvata arenifera. They were smaller than the aperture of the sac, and consequently only closed it imperfectly. On examining them with the microscope, I detected a fibrous structure in these opercula, arising from comparatively coarse-spun threads, sticking close together; at the margins of these opercula single threads protruded, by which they were united with the mouth of the sac. In my specimens of the sacs of Helicopsyche Shuttleworthi I perceived no opercula; they had probably fallen off, or perhaps were not formed when these sacs were collected. 
opening in the hinder whorls of the sac, although the animal with its empty, shrivelled body could easily force its way out through the uppermost narrow whorl, and through the narrow aperture at the apex of the sac. But there is probably another circumstance which prompts the caterpillar instinctively, whilst finishing and enlarging its sac, to introduce a lateral opening below the uppermost narrow whorl; I mean the eventual permission of the act of copulation, which in this case, from the peculiar form of the sac, could only be effected through a low lateral aperture of this kind.

This Sac-bearer was first mentioned by Réaumur*, but has since remained entirely unnoticed by entomologists. It is only very recently that greater attention has been given to these Heliciform caterpillar-sacs. My attention was first called to this Sac-bearer in Freiburg in the latter part of the summer of 1849 by Von Heyden, to whom entomology is indebted for so many interesting discoveries. It was discovered by Von Heyden spun down on rocks on the Schlossberg near Freiburg, and subsequently the same animal was found on the Isteiner Klotz be-

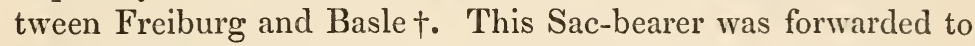
me by Zeller from the neighbourhood of Glogau, and I received several living specimens, collected a couple of miles from Vienna, near Mödling, through the kindness of Kollar, in whose company I afterwards (in the year 1850) collected many specimens in the same locality. Dr. von Frantzius also brought me some specimens of this Sac-bearer from Meran. By Herrich-Schäffer's intervention, I obtained many of the same sacs from the district of Tegernheim near Ratisbon, and this Sac-bearer was also observed by Mann and Zeller in Sicily $\neq$. Besides the habitat given by Réaumur, Besançon and Dijon in France have recently been indicated by Bruand as localities for this Sac-bearer $\S$. In

* See Mémoires pour servir à l'Histoire des Insectes, tom. iii. part i. edit. $12 \mathrm{mo}$, p. 249. pl. 15. fig. 20-22, figures of the sac of Psyche Helix (see the copies of these in my plate, figs. 10-12).

$\uparrow$ See Reutti's Uebersicht der Lepidopteren-Fauna des Grossherzogthums Baden, in the Beiträge zur rheinischen Naturgeschichte, Heft 3. 1853, p. 49.

† See my Bemerkungen über Psychiden, in the Jahresbericht der schlesischen Gesellschaft für vaterländische Cultur über 1850, p. 87 (transl. Ent. Trans. new ser. vol. i.).

\$ See his Essai monographique sur la Tribu des Psychides, in the Mémoires 
Bremi's collection at Zurich I saw specimens of this sac, which had been sent from Ticino and the Valais. By the kindness of Dr. Rosenhauer of Erlangen, I obtained a spiral sac, which was found near Malaga in Spain, and which, from its size, probably belongs to a species distinct from Psyche Helix. The form of this sac is exactly the same, but its breadth is 3 lines and its height $2 \frac{3}{4}$ lines.

The caterpillar of Psyche Helix selects various plants for its nourishment. On the Schlossberg near Freiburg it feeds upon Artemisia vulgaris. According to Zeller's testimony it also lives upon Anthyllis vulneraria, Lotus corniculatus, and Gnaphalium arenarium. Kollar found his on Atriplex laciniata. Near Ratisbon I observed these sac-bearing caterpillars feeding upon Alyssum montanum and Teucrium Chamcedrys. It is also stated by Bruand, that besides Cheiranthus odoratus and Scabiosa arvensis, this Sac-bearer was most frequently met with upon Teucrium Chamadrys. Reutti fed these caterpillars with Lamium purpureum, and I myself supplied them with Lotus corniculatus and Hippocrepis comosa. These Sac-bearers are leaf-miners after the fashion of the caterpillars of Coleophora, pushing their bodies far in between the epidermic plates of the leaves, through a round hole which they gnaw in the latter, and devouring the chlorophyll all round them, during which process the sac remains outside sticking with its aperture to the opening in the epidermis. The leaves, and even the variegated flowers of the food-plants are in this way often completely decolorized by the Sac-bearers. The caterpillars of Psyche Helix are of a dirty white colour; the head, the legs, the three thoracic segments, and the extremity of the abdomen possess a hard, blackishbrown integument. The constrictions of the thorax and also its median line are colourless (figs. 2, 4, $6 \& 7$ ). When taken out of the sac, the caterpillar, in creeping about, retains the same gentle spiral curvature of the body as when within the sac. When these Sac-bearers are full-grown, which is the case in the latter part of the summer, they quit their food-plants like the other caterpillars of the Psychide and seek a suitable place for their change to the pupa state. When they find stone walls de la Société d'Emulation du Doubs, Année 1852, p. 74. pl. 2. fig. 48 b (sac of Psyche Helix). 
or rocks in their vicinity they creep high up on them, and spin down the lower aperture of their dwelling firmly. In passing through the process of moulting also, these caterpillars, like all other Sac-bearers, always spin down their habitations temporarily. The evolution of the moth takes place in the same year*. If after some time we examine the spun-dlorn sac of a

* This Sac-bearer, like the other Psychida, is exposed to the attacks of Ichneumonida. It is remarkable that the Ichneumonidous parasite of Psyche Helix is a Chalcis, whilst I have never yet reared a Chalcis from the caterpillars of the other Psychida. This Chalcis, which was indicated to me by Kollar under the name of Chalcis nigra, does not, however, appear to occur very generally. Réaumur obtained it from the sacs of Psyche Helix found in France, as appears from his notice, slıort as it is (see Mém. pour serv. à l'Hist. des Ins. tom. iii. p. 250); the sacs collected near Mödling also furnished me with this Chalcis in abundance; but on the other hand, from more than a hundred sacs which I had obtained from Tegernheim near Ratisbon, no Chalcis, and indeed no Ichneumon at all, escaper. The Chalcis always eats its way out at the side of the sac between the first and second whorls, and leares a round hole corresponding with its size on the outside of the sac (fig. l $b$ ). This Chalcis (figs. 13, 14) belongs, according to Nees von Esenbeck's Hymenopterorum Ichneumonibus affinium Monographia, vol. ii. p. 27, to the species of the genus Chalcis described in Sectio II. (abdominis petiolo brevissimo); its specific character may be diagnosed in the following manner:-nigra, pubescens, scutello in medio marginis dente obtuso, femoribus posticis subtus obsolete unidentatis, tarsis piceis. Long. lin. $1-1 \frac{1}{2}$. The other Ichneumons reared by me from the caterpillars of Psychida are as follow :-

Campoplex difformis, Gr., from Fumea nitidella, Ochs.

— lætus, Rtzb., from Fumea betulina, Zell.

— lugens, Rtzb., from Fumea nitidella and betulina.

— psilopterus, Gr., from Solenobia lichenella, Linn.

Cryptus eborinus, Rtzb., from Fumea nitidella.

_ spiralis, Gr., from Talæporia pseudobombycella, Ochs.

Hemiteles albipennis, Rtzb., from Solenobia triquetrella, Fisch. $v$. R.

- areator, Gr., from Psyclie calvella, Ochs. and Fumea nitidella.

_ elongatus, Rtzb., from Talxporia pseudobombycella.

- gastrocolus, Rtzb., from Solenobia triquetrella and lichenella.

— imbecillus, $G r$., from Fumea nitidella.

— leucomerus, Rtzb., from Solenobia triquetrella, Fisch. v. R.

_ melanarius, $G r$., from Solenobia triquetrella.

- similis, Gr., from Psyche calvella.

_tristator, $G r$., from Fumea nitidella.

_ 1 nov. sp. from Fumea betulina.

- 2 nov. sp. from Talæporia pseudobombycella.

Microgaster longicauda, Wesin., from Solenobia lichenella.

Pezomachus agilis, Gr., from Psyche calvella. 
Psyche Helix during its period of pupation, we find the pupa in the lower whorl of the case, with its anterior extremity directed upwards, and its hinder extremity downwards towards the attached lower aperture. Between this and the extremity of the abdomen of the pupa, the shrivelled skin of the caterpillar stripped off in its last change of skin is always tixed, so that this caterpillar, like all the caterpillars of the Psychida, turns itself round in the sac before the true pupation. In all the sacs of Psyche Helix in the pupa state, hitherto examined by me, of which I. have had the opportunity of observing more than a hundred and fifty within seven years, I never found any but a female pupa. This is motionless, of a yellowish-brown colour, and with very indistinct segments; it presents a body which is slightly diminished in front, and gently curved in a spiral form corresponding with the lower spiral whorl of the sac (fig. 5).

The wingless and almost footless female moth which is evolved from this pupa, also appears slightly curved in a spiral (figs. 8, 9). Its colour is grey, with a very slight brown tint on the back of the three thoracic segments. The anterior extremity of the body is somewhat narrowed; the exantennate head, which is strongly bent downwards, exhibits very indistinct and quite abortive oral organs; and on each side of it two dark pigment-spots are perceptible, which however contain no eye-facets. The abdomen is sparingly beset with white hairs. The varicose urinary vessels shine through the skin of the body here and there with a whitishyellow colour, as does also the violet ventral chain of ganglia. The movements of these females of Psyche are extremely sluggish, and the six little feet of the three thoracic segments, which are in

Pezomachus cursitans, Gr., from Psyche graminella, Ochs.

__ geochares, Först., from Fumea nitidella.

_ pedestris, Gr., from Psyche calvella and Fumea nitidella.

1 nov. sp. from Psyche calvella.

2 nov. sp. from Psyche calvella.

Phygadeuon tenuipes, Gr., (?) from Fumea nitidella.

Pimpla annulicornis, Rtzb., from Psyche graminella.

_ examinator, Gr., from Psyche graminella, Fumea betulina and nitidella.

_ scanica, Gr., from Psyche calvella and Fumea nitidella.

Pteromalus Zelleri, Rtzb., from Fumea nitidella. 
the form of very short conical processes, scarcely take any part in them. A dissection which I made of several of these animals, convinced me that I really had female insects before me; the internal and external organization of their sexual organs being exactly the same as in other females of Psyche. The two sexual orifices presented themselves in all the individuals, as well as the copulative pouch and seminal receptacle, both of which of course were always empty. The eight ovarian tubes only contained a very few eggs.

Like all other true species of Psyche these female moths deposited their yellowish eggs in the empty pupa-case, which, in Psyche, always remains behind in the caterpillar-sac; they then shrivelled up to a very small volume, when they generally left the sac by the above-mentioned lateral aperture and soon afterwards died.

The unfertilized eggrs, concealed in the pupa-case, are also developed in the same year. If a spun-down sac of Psyche Helix be opened in the latter part of the autumn or in winter, we always find from ten to four-and-twenty young, reddish-grey caterpillars in the interior of the pupa-case. On the empty colourless egg-shells, which may be found crushed between the caterpillars, the micropyle is distinctly recognizable under the microscope.

After I had thus never detected any other mode of reproduction but that by Parthenogenesis in Psyche Helix, it necessarily astonished me that other entomologists should have succeeded in obtaining the males of this species. On a closer examination, however, it appears doubtful whether the moths described as males of Psyche Helix really belong to this species. Thus the male of a Psyche helicinella was figured by Herrich-Schäffer, together with a sac of Psyche Helix*. The moth figured was discovered by Mann in Sicily: as an empty sac of Psyche Helix occurred in its vicinity, Mann supposed that the moth had escaped from this sac. Herrich-Schäffer himself, however, leaves it doubtful, whether this spiral sac really belonged to the moth figured by him, saying, "the sac (if really belonging thereto) is like a snail-shell, formed only of grains of sand, without portions of

* See his Systematische Beschreibung der Schmetterlinge von Europa, Band ii. p. 21. figs. 108,109 . 
plants." For this reason I have retained the name of Psyche Helix, which I gave to the female moths reared by me from the snail-like sacs, as it is not yet proved that the Psyche helicinella of Herrich-Schäffer actually belongs to my Psyche Helix. The same applies to the male moth described and figured by Bruand as Psyche helicinella*. Bruand describes as belonging to Psyche helicinella, the female and sac-bearing caterpillar of my Psyche Helix, but says expressly, that he has never been able to rear this Sac-bearer to the evolution of the moth $\dagger$. From this, therefore, we have no certainty that the winged individuals of Psyche helicinella, taken in the open air by Bruand, are the males of $\mathrm{my}$ wingless female Psyche Helix. As the males of Psyche copulate with their females whilst concealed in the interior of the sac, and for this purpose push their abdomen into the hinder free aperture of the female sac, the male of Psyche Helix will also perform this action, and will therefore probably possess an abdomen curved to correspond with the convoluted sac of the female. No such curvature of the abdomen is perceptible in either of the males figured by Herrich-Schäffer and Bruand, from which my doubts above expressed gain still greater support. Further observations, therefore, are to be made as to the existence of the male individuals of Psyche Helix. Perhaps those two flat spiral sacs which I have previously described (p.28 note*) as belonging: to a distinct species of Psyche (Ps. Planorbis) may be produced by the caterpillar of the male Psyche Helix, which would be by no means very improbable, as the caterpillar-sacs of certain other Psychida differ in form and size according to the sexes. The most striking example of this kind is presented by Solenobia

* See his Essai monographique, \&.c. ut cit. supra, p. 73. pl. 2. fig. 48 a.

+ Upon this Bruand expresses himself (p. 74) in the following manner:"Cette chenille est fort difficile à élever, et, pour ma part, après trois essais successifs, j'ai renoncé à obtenir le papillon en domesticité. Il est probable que quelques circonstances atmosphériques (la rosée matinale, par exemple) sont nécessaires à son éclosion. La chenille se nourrit très-bien jusqu'au moment de sa transformation; alors elle commence à errer çà et là dans le vase ou la boîte qui la renferme, enfin elle se fixe auprès les parois .... puis rien n'arrive; elle meurt misérablement." With me, the rearing of these Sacbearers after they were nearly full-grown, to the evolution of the female, has not been attended with difficulty, in spacious airy breeding-cages, and with a cunstant supply of fresh food (Lotus corniculatus). 
clathrella, Zell.* I also leave it undecided, whether that larger sac already mentioned by me (p. 32), which, except in its size, differed in nothing from the sacs of the female Psyche Helix, does not belong to a caterpillar, which might have become developed to a male individual of Psyche Helix $\dagger$.

* See Zeller's Beschreibung des männlichen und weiblichen Sackes der Solenobia clathrella, in the Linna Entomologica, Band vii. 1852, p. 345. See also Fischer von Röslerstamm, Abbildungen zur Berichtigung und Ergänzung der Schmetterlingskunde, p. 84. taf. 38.

+ [May not the Psyche Planorbis and the larger heliciform-sac, both from Spain, be the male and female saes of one species, and the male sae of P. Helix be also Planorbis-like, but smaller than the Spanish specimens?-W. S. D.] 
WhiLst I was occupied with my task of establishing a Parthenogenesis in Psyche Helix, and Solenobia triquetrella and lichenella, I did not omit to bring within the limit of my investigations other insects also, of which the story went that the females were capable of independent reproduction in the virgin state without the assistance of a male individual. It was of importance to look carefully at the Honey-Bee, upon the reproduction of which the most extraordinary statements have been made at all times by the various Bee-keepers. Amongst these statements my attention had already long been turned to that remarkable faculty which was ascribed to certain Wurker-Bees, and which was said to consist in their being able to lay eggs capable of development without copulation *. In the year 1851, therefore, I put myself in communication from Breslau with various Bee-keepers, and in this way became acquainted with the distinguished Apiarian Dzierzon, pastor at Carlsmarkt near Brieg in Silesia. By this Apiarian, who is gifted with an admirably acute power of observation and free from prejudices, I was furnished, partly in letters and partly by word of mouth, with information upon the œeconomy of Bees and the most important phænomena of Bee-life, of a kind such as I could never have obtained from zoological and entomological works. What surprised me most in these communications, was the entirely new theory of reproduction which Dzierzon had established, with which he then made me

* [Hunter, in his paper "On Bees," Phil. Trans. 1792, refers to this opinion, but had been unable to confirm it. "It is asserted by Riem, that when a hive is deprived of a queen, labourers lay eggs."..." and Wilhelm says that it is the labourers only that lay drone-eggs." Hunter then quotes from Schirach :"A young queen lately hatched was put into a hive, which had been previously ascertained to contain no drones, and whose queen was removed; and yet the young queen laid eggs." Upon which he remarks- "There is no mystery in this; but did they hatch?" The definite reply to this question, and the nature of the product of the virgin-egg, are amongst the valuable facts in the present work.-R. O.] 
acquainted, and by which all the phænomena relating to the process of reproduction in the Bees, which so often border upon the marvellous, may be completely explained.

One of these remarkable phænomena is the property just referred to possessed by some $\mathbf{W}$ orker-Bees of laying eggs capable of development, a property which is denied by no observant Beekeeper, but could not hitherto be satisfactorily explained in any way. The dissection of the Worker-Bees had shown, that they possess undeveloped ovaries, that the seminal receptacle is only imperfectly developed in them, and that, by reason of the abortion of their copulative organs, they are by no means in a condition to copulate with a Drone (a male bee) and allow themselves to be fertilized by him. But whence then should this reproductive faculty of certain Worker-Bees arise? At first I attempted to bring this reproductive power into connexion with the Alternation of Generations, and expressed the supposition* that similar circumstances might occur amongst the Bees as amongst the Aphides, and that consequently amongst the Bees individuals were produced at certain times, which, as nurse-like creatures, could produce brood, without fertilization. But if nurses really did occur in the Bee-colonies, these must have been recognizable by careful dissection, as instead of ovaries they would contain germ-stocks, and no trace of a seminal receptacle. I at the same time expressed the wish that I might soon have an opportunity given to me of submitting Bees, which had been ascertained to be fertile workers, to a careful dissection and microscopic examination, in order to decide whether or no they really were nurses.

But when I became acquainted with Dzierzon's theory of the propagation of the Bees, and constantly grew more and more convinced of its correctness, it was evident to me that we cannot speak of a nurse-formation among'st the Bees. To inform myself as completely as possible about this theory, I went myself to Carlsmarkt and held a conference with Dzierzon on the 26th July 1851, in which I opposed all possible doubts to his theory

* See my Bemerkungen über die Lebensweise und den Haushalt der Bienen, in the Jahresbericht der schlesischen Gesellschaft für vaterliindische Cultur im Jahre 1851, p. 48. 
of reproduction; but these were constantly set aside by him, and with such convincing reasons, which could be brought into accordance both with the anatomical relations of the Bees and with the physiological laws of insect and animal life in general, that at last I could no longer hesitate in admitting the correctness of Dzierzon's theory of reproduction.

Dzierzon expressed his views upon the reproduction of Bees in the year 1845 in the Bienenzeitung of Eichstadt*, but without particularly emphasising the most important details of his theory, and without elevating it into a peculiar theory. I consider it necessary to reproduce the views expressed by Dzierzon in that Journal, word for word. They run as follows:-

"Presupposing, what will be referred to and proved in the following Numbers, that the Queen (female bee) to become good for anything must be fertilized by a Drone (male bee), and that the copulation takes place in the air, I express the conviction, from which all phænomena and mysteries may be perfectly explained, that the drone-eggs do not require fecundation; but that the cooperation of the Drones is absolutely necessary when Worker-Bees are to be produced. Whilst in the higher animals the male is the perfect and ruling creature-the bull keeps together and as it were governs the herd of cattle, and the cock does the same by the hens-the reverse of this takes place in Insects. In the Wasps, Hornets, Humble-Bees, Ants, and especially in the Bees, the perfect female forms the central point and holds the swarm together. As even the drones are subordinated to her, they are also in themselves altogether imperfect creatures, for the production of which so many forces and conditions are not necessary even on the part of nature as for the production of the queen, and, what is the same thing, of the workers. (The ancients even appear to have indicated this by the denomination Fucus.) The truth of this assertion appears at once from the fact, that as everything that is capable of the more difficult and greater effect may also produce the easier and smaller one, so every stock, which is in a condition to produce worker-bees, may also produce drones, when suitable cells are not wanting in the nest; but not inversely. In copulation the ovaries are not

* See Bienenzeitung, herausgegeben von Dr. C. Barth und A. Schmid in Eichstadt. Jahrgang i. 1845, p. 113. 
fecundated, but the seminal receptacle, that little vesicle or knot which in the young queen is filled with a watery moisture, is saturated with semen, after which it is more clearly distinguishable from its white colour. The activity of the ovary in the normal state only commences after copulation, but is not necessarily caused thereby; hence many unfecundated queens lay no eggs at all, whilst others lay drone-eggs; and even workers do the latter, although, from their want of a seminal receptacle, I regard them as quite incapable of copulation. I am convinced that such eggs are sufficient for the production of drones, whilst the egg from which a queen or a worker is to be developed must come in contact with the filled seminal receptacle. This is certainly only a hypothesis, and will probably remain so, but one to which every close observer will be no more able to refuse his assent, than the hypothesis of Copernicus, that the earth turns round upon its axis; for all the mysterious phænomena in the commonwealth of the Bees are very simply explained by it."

In a separate Bee-book, Dzierzon subsequently summed up his views upon the reproduction of Bees as a regular theory in the following manner $*$ :-

"Therefore, and this must be well borne in mind, in the copulation of the queen, the ovary is not impregnated, but this vesicle or seminal receptacle is penetrated or filled by the male semen. By this, much, nay all of what was enigmatical is solved,-especially how the queen can lay fertile eggs in the early spring, when there are no males in the hive. The supply of semen received during copulation is sufficient for her whole life. The copulation takes place once for all. The queen then never flies out again, except when the whole colony removes. When she has begun to lay, we may, without scruple, cut off her wings; she will still remain fertile until her death. But in her youth, every queen must have flown out at least once, because the fertilization only takes place in the air; therefore no queen, which has been lame in her wings from birth, can ever be per-

* Theorie und Praxis des neuen Bienenfreundes, oder neue Art der Bienenzucht mit dem günstigsten Erfolge angewendet und dargestellt von Dzierzon, 2 anf. (without place of printing) 1849, p. 106. Dzierzon expressed himself in exactly the same way in a Supplement to the Theorie und Praxis, published in 1852, p. 4 et seq. 
fectly fertile: I say, perfectly fertile, or capable of producing both sexes. For, to lay drone-eggs, according to my experience, requires no fecundation at all. This is exactly the new and peculiar point in my theory, which I at first only ventured to put forward as a hypothesis, but which has since been completely confirmed. Three young queens with imperfect wings have occurred during the past summer, and these, although, from the imperfection of their wings, they could evidently never have taken the fertilizing flight, and also on dissection proved to be unfecundated, nevertheless laid drone-eggs*." - By this, all the mysteries which we have hitherto vainly endeavoured to unriddle, are completely solved. In the first place the enigma: Why is it that many mothers-they may be either queens or workers in their form-are only capable of propagating the male sex or drones? Because the former are either unfecundated, or their fertility is exhausted; the latter, on the other hand, are incapable of fertilization."

"For I am firmly convinced that the egg-laying worker-bees, which occur abnormally, are, from the want of a seminal receptacle, just as little capable of being fertilized, as the young queens from the want of sound wings. Moreover there is certainly no doubt, that by the peculiar tone of her wings the queen allures the drones to her, and disposes them to copulation, of which a worker is of course incapable. In the second place, the before-mentioned power of the fertile queen to lay workerand drone-eggs at pleasure, is rendered very easy of explanation by the fact, that the drone-eggs require no impregnation, but bring the germ of life with them out of the ovary; whilst otherwise it would be inexplicable and incredible. Thus, as it has already been shown that the ovaries are not impregnated, but that the seminal receptacle is filled, during copulation, the queen has it in her power to deposit an egg just as it comes from the ovary and as the unfecundated mothers lay it; or by the action of the seminal receptacle, past which it must glide, to invest it

* [Here Hunter would perhaps have repeated his question, "But did they hatch?" The particulars of the experiment by which Dzierzon knew that drones came out of these eggs are not detailed ; the fact, howerer, is establisherd by the observations of Siebold and Leuckart, given in a subsequent part of the work.-R. O.] 
with a higher degree, a higher potency of fertility, and awaken in it the germ of a more perfect being, namely a queen or a worker-bee. This of course she does instinctively, induced by the width of the cell to be furnished." - "For the production of females in the bee-hive, therefore, more conditions and forces are necessary than for the production of males or drones. Every mother which is capable of producing worker-brood, can also lay drone-eggs, but not inversely."

As was to be expected, these views upon the reproduction of Bees called forth the most lively contradictions amongst the Beekeepers; they were attacked with the most violent polemics in the Bee-journal above mentioned, at the same time however that most of the opponents, being destitute of any knowledge of the anatomical structure of Bees, and of any insight into the physiological import of the sexual functions in Insects, laid themselves open so miserably, that it must have been an easy matter for Dzierzon to silence them; but as it was almost entirely dilettanti speaking to dilettanti, the dispute never came to an end, the most incorrect, extraordinary and absurd assertions upon the copulation, fecundation and oviposition of the Bees, \&c. being put forward in sober earnest as established truths, without its being observed how completely such views, devised in the fancy of a Bee-keeper, were destitute of anything like scientific proof. Hence it was possible that, simultaneously with the theory set up by Dzierzon, which its originator sought to support by important new evidence from time to time in the Bienenzeitung, questions for investigation and reply were again and again propounded in that Journal, upon which we must have been long perfectly clear, since the most important points in the reproduction of the Bees had been elucidated by Dzierzon's theory.

Thus in the different years of the Bienenzeitung up to the most recent time, we may find the following questions put forward as not satisfactorily answered, and the following points referred to as doubtful by various Bee-keepers : namely, whether the drones are really the male Bees; whether the drones might not have the care of the hatching of the eggs; whether the drones are not truly abortions; whether there are not also male worker-bees; whether the queen is not perhaps fertilized by 
caressing or by mere agitation; whether the copulation between the queen and a drone does not after all take place in the beehive, and more of the same kind.

In opposition to these variously contradictory questions, I, as Vice-president of the third meeting of German Bee-keepers, held on the 2nd June, 1852, at Brieg in Silesia*, gave an exposition of the anatomical relations of the three kinds of Bees, the drones, the queen, and the workers, and called upon the Bee-keepers present to express their objections and doubts against the particular points of the theory established by Dzierzon. This was done on several sides; Dzierzon, who was present as President of the Society, defended his assertions with the means which his abundant observations, conceived with a correct understanding, furnished to his hand, whilst I came to his assistance with my observations made with the dissecting needle and the microscope, whenever reference was made to the different anatomical relations and the signification of the internal and external sexual organs of the Bees.

Although the majority of the Apiarians did not so quickly drop their preconceived notions and incorrect views as to the œconomy, and especially the reproduction, of the Bees, yet a constantly increasing number of voices was gradually raised in the Bienenzeitung to confirm the correctness of individual points in the theory of reproduction put forward by Dzierzon. People began to interest themselves in the anatomical structure of the Bees and of insects in general; they took notice of the knowledge obtained in recent times by the microscope, by which a clearer view of the function of the male seminal fluid in the interior of female insects had been gained. To strip everything doubtful from those assertions in Dzierzon's theory which still had too much of the garb of a hypothesis about them, and allow them to appear as naked truths, those Apiarians, whose sole object was to get at the truth, took care that various individual Bees, the exact examination of whose condition might furnish the right explanation of different doubtful points in Dzierzon's theory, were handed over to practised entomotomists for a dissection and opinion. In this way this theory constantly gained in firmness and form, and became strengthened in such a

* See the Bienenzeitung, Achter Jahrgany, 1852, 1. 117. 
manner that it may now claim to have taken root in the soil of science, there to await a further development. Great merit, in regard to the recognition of Dzierzon's theory, is due to Baron von Berlepsch of Seebach, near Langensalza in Thuringia, as that intelligent and experienced Apiarian neither shunned sacrifices, time or trouble to obtain the most important information upon the hotly contested questions relating to the reproduction of Bees from his numerous Bee-colonies, which are extremely well arranged for observation. In a series of Apistical letter's Berlepsch* has given a systematic exposition of the new theory of the reproduction of the Bees, and supplied the individual positions with proofs supported upon the most arduous experiments, by which he has shown himself to be a distinguished observer and acute naturalist.

It must also be mentioned that Dzierzon deserves to be celebrated as making an æra not only in the theory, but also in the practice of Bee-keeping. He has, namely, given the Bee-hive an arrangement, by which it becomes possible for the Bee-keeper not only to follow the observation of the individual Bee-colonies and to check the proceedings of their individual members or of the foreign intruders in the most exact and certain manner. but also to control and guide the entire œeconomy of the individual hives from all sides. He hit upon the happy idea of causing the Bees to build their combs from transverse sticks placed loosely behind one another in the upper space of the bee-hive, by which he was enabled as often as he pleased to examine the whole of the combs in a hive one after the other, the interior of the hive being rendered accessible by taking: away a moveable back or front wall,-as by this arrangement each individual comb, clinging from beneath to the loose transverse stick, can be taken out with this, examined on both sides, and again suspended in its place without injury. By the help of this ingenious arrangement $\psi$ it had become possible for Dzierzon

* These Apistical letters are published in the Eichstadt Bienenzeitung for the years 1853 and 1854, and form an extremely important document for our knowledge of the history of reproduction in the Bees and Insects in general.

+ As the lateral adhesion of the combs built down from the sticks frequently rendered their removal difficult, Berlepseh tried to avoid this inconvenience in a very ingenious way, by suspending in his lives, instead of the sticks, small quadrangular frames, the vacuity of which the Bees fill up with their comb, ly 
not merely to trace what went on in a bee-hive from day to day, or from hour to hour, - he could even convince himself most exactly, with his own eyes, at any time, as to what was taking place in every individual cell of the different combs in his hives. $\mathrm{He}$ was also enabled in this way to procure a knowledge of all the proceedings of the workers in the interior of the hive between the combs, and also to witness the doings of the queen bee. These were all advantages which even the celebrated hives with glass walls could not in the least present, as these latter beehives only permitted the surface of a single comb which was turned towards the glass to be inspected, but otherwise allowed but a very small and extremely imperfect insight into the interior of a colony of Bees.

Dzierzon could give the most exact account of the condition of his bee-hives. He knew the number and kind of the cells which were daily or hourly supplied with eggs by the queen; he knew in what time the larvæ in the eggs laid arrived at their exclusion; he was enabled to observe the gradual growth of the larva; he could exactly ascertain what kind of food was furnished to this or that larva by the workers; he could acquire the most positive information as to the time of pupation of a beelarva, as to the period of the escape of the Bee from the covered cell, and as to the number and nature of the queen's cells; in this way he was always informed in what condition the queen governing a bee-hive was; he could detect every disturbance, every irregularity, which, induced by multifarious circumstances, easily occurs in the well-ordered œconomy of a hive, as quickly as its cause.

What advantages this must have afforded to an Apiarian endowed with such an acute and unprejudiced power of observation as Dzierzon, may be easily imagined. By this agency the most important and instructive information regarding the proceedings of a Bee-colony might flow in upon that acute observer, and it could not but happen that at last the extremely remarkable and concealed process of the reproduction of the Bees would be correctly penetrated by the eye of man.

which the removal and suspension of the combs are greatly facilitated, and altogether such a convenient arrangement is given to the Dzierzon hive, that nothing more remains to be desired. 
But even for practice the Dzierzon bee-hives were of the greatest importance, for Dzierzon could know exactly, at any time, and of any one of his bee-hives, how strongly it was peopled, how industrious its inhabitants were, and what they were occupied with. He could always inform himself whether the number of workers was in proportion to that of the brood produced by the queen, whether the number or presence of dronelarvæ was or was not useful to the hive, whether the necessary store of food was present, \&c. With all this, the intelligent Beekeeper and possessor of Dzierzon hives, by the aid of which a complete insight into the state of each household of Bees might be attained, could exercise a directing and correcting action, by adding the wanting number of necessary workers to a hive which was poor in workers, or taking away some of the combs filled with eggs and brood from another scantily-peopled hive, so as to lighten its work, and hanging them in an abundantly-peopled hive for further care. The careful Bee-keeper now knew from what hives he had to remove the combs filled with drone-larvæ which were either unnecessary or dangerous ; he was enabled to save a hive, the inhabitants of which, although otherwise industrious, threatened to become demoralized by the loss of their queen, from this dangerous state of anarchy, by taking care to replace this loss, where the Bees themselves omitted to do so. In short, with the assistance of Dzierzon's hives, an experienced and careful Bee-keeper may go to work like an intelligent gardener, who, by cutting a way the unnecessary shoots, and attending properly to the bud-bearing twigs, prepares and supports his trees for the production of a rich harvest of fruit*.

* Although it is several years since Dzierzon gave his "New Theory and Practice of Bee-keeping" to the knowledge and use of the public through the medium of the press, the advances made by Dzierzon in Bee-keeping have only been able to make their way slowly and gradually in the circle of Beekeepers; nay, it took still longer before the assertions of Dzicrzon relating to the reproduction of the Bees passed out of this circle to reach the ears of a physiologist and naturalist. For this, Dzierzon himself is to blame; this Apiarian, otherwise so practical, hesitated to give his manuscript upon "Theory and Practice" to a respectable bookseller for publication, but preferred making known his inventions and discoveries in an extremely unpractical war, by allowing his Nene Theorie und Praxis to appear at first as published by him- 
In turning to the more exact exposition of Dzierzon's theory of the reproduction of Bees, I give prominence to the most important points in the history of their propagation, upon the establishment of which Dzierzon must have laid particular stress, as a number of the proceedings in a bee-hive relating to reproduction can only find their correct explanation and elucidadation if we maintain, that the young unfecundated queen never copulates in the bee-hive, but always outside this, high up in the air. I pass over the lively dispute which has been carried on amongst Bee-keepers from time immemorial for the defence or rejection of this point, and only refer to the fact that a queen has never been surprised in the act of copulation within the bee-hive by any Apiarian who has obtained an insight into the interior of a hive by the employment of Dzierzon's hives. The drones, as long as they remain in the hive, are always extremely sluggish insects, which are not even roused from their quietude and phlegm by the proximity of a queen desirous of copulation; on the other hand, when a warm, clear and still day has allured them out into the open air, the sexual and copulative impulse

self, and afterwards disposing of it to a private individual living in a village in Silesia for further distribution. Von Berlepsch justly complains of such a proceeding (in the extra Supplement to No. 21 of the Eichstadt Bienenzeitung, 1852), as he, and with him many other Apiarians, were prevented by this awkward and troublesome arrangement from an early adoption of the true Dzierzon method of Bee-keeping; for (as Berlepsch expresses himself upon the Dzierzon hives) the invention of being able to take out the individual combs suspended from little sticks, is undoubtedly the most practically important one that has ever been made in Bee-keeping, and one which must necessarily reform, that is to say, antiquate all previous methods, and to which alone Dzierzon is indebted for the excellence of his breeds, and the almost complete revelation of the natural history of Bees, their mode of life and of working. After Dzierzon had sold his intellectual property into strange hands, which withheld the most important part of his method, the right construction of the true Dzierzon hives, from the public, he made another attempt to bring his "Theory and Practice of Bee-keeping" into general notice, by printing in the year 1854 the Bienenfreund aus Schlesien, a monthly journal of instruction and entertainment for lovers of nature in general, and Bee-keepers in particular. Of this journal (published by Ad. Bänder in Brieg) twenty-five numbers have appeared up to this time ; but I fear that, from its inconvenient form, and the somewhat diffuse style of the text, this means selected by Dzierzon is not adapted to make the public acquainted and familiar with the real essence of his theory and practice. 
is awakened in the highest degree in these otherwise so sluggish drones. They rove through the genial air high over their hives with a loud humming to attract the attention of a queen, who would be impelled to take her wedding-flight by the same favourable weather. At any rate, very few of the many thousand drones attain the longed-for happiness of being selected and accepted by a queen for a husband, it being well known that the number of female Bees is very small in proportion to the great number of male individuals. But by means of this disproportion, the few female Bees, on taking their wedding-flight, are always sure of attaining their object, as from the number of drones roving through the air with the same intent, it will not be difficult for a queen to make choice of an agreeable consort.

That the copulation of the Bees takes place in the open air, is certainly nothing remarkable, as we see so many other insects perform the act of copulation whilst flying freely about in the air. It is true that the copulative act is very quickly completed by the Bees, and this is proper to all those insects in general, which, with the Bees, belong to the order Hymenoptera; whilst the males and females of insects of other orders usually remain for days closely united in copulation. For this reason it is one of the rarest events for even the most observant entomologist to surprise a pair of Hymenoptera in flagrant $i^{*}$. The Bee-keepers therefore must not be surprised that the act of copulation in Bees has hitherto been so little observed. However, it has accidentally been seen now and then by human eyes, when a pair of bees, united in the act of copulation, dashed down upon the earth from the upper regions of the air. Such isolated observa-

* This is the reason why we find so many individual females or males placed as separate species in no other order of the class of Insects as in the Hymenoptera; as in these inseets the male and female individuals are often quite differently coloured and marked, and as no trouble has been taken with the rearing of them, as has been done with the Lepidoptera, it has hitherto been impossible with many of these Hymenoptera to discover the sexes belonging to the same species. Gravenhorst is therefore to be excused if he has established a quantity of speeies of Iclneumons (in his Ichneumonologia Europea) which only consist of males or females. This eertainly did not happen from that desire which is carried so much too far by many entomologists, of having the fame of giving a name to species which are new, but not founded in nature. 
tions, information upon which has also been given in the Bienenzeitung*, are certainly sufficient evidence that the Bees copulate outside the hive.

A still more convincing proof of the occurrence of this act of copulation in the open air is furnished by the appearance and behaviour of the fertilized queen on her return from her wedding-flight. The completion of the coïtus of such a queen may betray itself even externally; not only does the external orifice of the sexual apparatus, which was kept closed before the wedding-flight, stand open, but the torn male copulative organs remain sticking in the vagina, and partly protrude from it. In order to determine with certainty from its nature what this foreign body, which had often been detected $\uparrow$ in the vagina of a queen on her return from the wedding-flight, really was, Baron von Berlepsch forwarded to me for careful examination, on the 21 st July 185.3, one of these queens, from the gaping sexual orifice of which definitely formed parts protruded $\ddagger$. The results with which the exact anatomical and microscopical examination of this queen has furnished me, have been given by me in the Bienenzeitung $\$$. By this analysis I

* See Bienenzeitung, 1845, p. 38; 1852, p. 188; 1853, pp. 108 \& 174.

† Bienenzeitung, 1846, p. 95, and 1853, pp. 43, $107 \& 120$.

\$ The letter from Von Berlepsch, which accompanied this quecn, contained, amongst other things, the following notes :- "Uninterruptedly occupied in clearing up the natural history of the Honey-Bee, that is to say, in bringing it to final conclusions, I succeeded, to-day, in impaling upon a pin, a queen which had flown out to copulate, just as she was about to re-enter the hive. The signs of copulation stand far out. In taking the liberty of sending you this carcase, I have to beg that you will have the kindness to settle by dissection, -1 , if any, and what, parts of the drone occur in the royal vulva; and 2 , what is the condition of the seminal receptacle. If there be parts of the drone in the vulva, people will at last admit that the drones are the males, that the copulation takes place outside the hive, and that it is absurd to describe the drones as abortions, and seek the males amongst the workerbees. Moreover, if you find the seminal receptacle filled with semen, Dzierzon's hypothesis, according to which the ovary is not fertilized but the seminal receptacle filled with male drone-semen by copulation, is raised into evidence."

§ See Bienenzeitung, 1854, No.20. p. 22\%, Zergliederung einer vom Begattungsfluge heimgekehrten Bienenkönigin. Ein Sendschreiben an Herrn August von Berlepsch in Seebach. I have at the same time made use of this letter to explain to the Bee-keepers the anatomical conditions of the sexual organs of 
was able to establish, that those definitely-formed parts in the vagina of the queen were nothing but the torn copulative organs of a male bee (drone). An intimate union of the two scxes of Bees must therefore have taken place here. The remaining

the Bees, so that they might be at last convinced that the import of the drones, queen, and workers in a colony of Bees could only be rightly estimated by taking these conditions into consideration. That this was not superfluous, was shown me by the thanks, repeatedly expressed in the Bienenzeitmng, with which my instruction was received by many friends of Bee-keeping. I thought it my duty also to render this service to the Apiarians, when I remembererl what has been made known up to the present day as to the various erroneous opinions asserted by Bee-keepers with regard to the history of reproduction in the Bees (see supra, p. 2). To show into what wrong paths those Bee-keepers, who, entirely mistaking the objects laid before them by nature, only wish to pass off their own peculiar opinions, have got, I quote here literally from Magerstedt's Pratkisches Bienenvater (oder Anleitung zur Kenntriss und Behandlung der Bienen, 1842, p. 68) what he teaches as the natural history of Bees :- "The queen is the mother of all the worker-bees. Of these the greater number are of the male, the smaller number of the female sex. She lays the eggs of both kinds in the small narrow cells of the building. The care of the brood is the duty both of the male and female worker-bees, but at the same time they are assisted, for the furtherance of the work, by the sexless drones, and for this reason the number of the drones is greatest at the time when the most brood occurs. Their business is especially to warm the brood, and to elerate the temperature of the hive during the time when the workers are occupied ont of doors. When, with a deficiency of nourishment and a dimimution of the business of taking care of the brood, their presence is no longer necessary, they are expelled. The queen, however, does not copulate. Her first fertilizing flight agitates her ovary, and by this means she becomes capable. of laying fertile eggs." This book, tainted with such gross errors heaped one upon another, has recently made its appearance in a third edition. Von Berlepsch has assured me that he sent its author my letter, in orler that he might change his opinion. But now, in this third edition, which appeared in 1856, we may read at p. 181 :- "The queen is the mother of all the workerbees; a greater number of the workers is of the male than of the female sex. Nature has distinguished both sexes externally. The queen is rendered capable of reproduction, not by copulation, but by the agitation of her ovary, and by its actions during the fertilizing flight, which is to be repeated several times. The female bees are also rendered capable of laying eggs by flying out, and by the agitation of their ovaries thus produced. From the eggs laid by the female bees, drones are produced, and these being perfectly asexual, do not cooperate in the business of reproduction, but in the care of the brood." And also at p. 279 :- "Certainly they (the drones) are not necessary for the fertilization (of the queen)." What shall we say to such a complete ignoring of the truth? 
behind of torn portions of the male sexual organs in the interior of the female vagina, is, however, a circumstance which occurs not unfrequently in other insects, especially in Beetles. With this condition of the external sexual organs of the queen examined by me, the state of the internal generative organs also agreed exactly, for the seminal receptacle (seminal vesicle), which is empty in all virgin female insects, was in this queen filled to overflowing with spermatozoids (seminal filaments)*. This queen therefore had returned to her hive certainly fertilized, and would have possessed the power for a long time of effecting the

* [The experiment by which Hunter distinguished the seminal-sac from the poison-sac in the complex female apparatus of the Queen-bee is ingenious and characteristic: "To ascertain which was the poison, I dipped points of needles into both (bags), and pricked the back of the hand; and those punctures that had the fluid from the first-lescribed bag in them grew sore and inflamed, while the others did not."-Phil. Trans. 1792, p. 190.

He applied this anatomical knowledge to explain the impregnation of insects, as follows :- " Insects, respecting the males, are of two kinds : one, where the male lives through the winter as well as the female; and the other where every male of that species dies before the winter comes on; among which may be considered, as a third, those where both male and female die in the same year. Of the first I shall only give the common Fly as an instance; of the second I shall just mention all of the Bee tribe; and the third may be illustrated in the Silk-worm. The mode of impregnation, in the first, is its being continued uninterruptedly through the whole period of laying eggs; while in the second, the copulation is in store; and in the third, the female lays up by the copulation a store of semen, although the male is alive."-1bid. p. 185 .

Hunter then proceeds to detail a series of experiments marle to determine the influence of the contents of the spermatheca of the female Silk-moth upon the eggrs, "which experiments," he says, " may be applied to the Bee, and many other insects." Of these experiments it will suffice to cite the following as illustrating his knowledge of that part of the mechanism of the female organs in the Moth and Bee on which so much of the important facts in the present work depends :-

"Experiment II.-I took a female Moth, as soon as she had escaped from the pod, and kept her on a card till she began to lay. I then took females that were fully impregnated before they began to lay, and dissected out that bag which I supposed to be the receptacle of the male semen; and, wetting a camel-hair pencil with this matter, covered the ova as soon as they passed out of the vagina. These ova were laid carefully on the clean card, and kept till the ensuing season, when they all hatched at the same time with those naturally impregnated. This proves that this bag is the receptacle for the semen, and it gradually decreases as the eggs are laid."-Phil. Trans. 1792, p. 188.R. O.] 
necessary fertilization of the eggs during oviposition with this supply of male semen.

As in the act of copulation of the Bees, the penis of a drone is completely protruded outwards, and as no particular muscular apparatus exists for the extrusion of the penis, the circumstance that the drones only copulate in flight has an important signification, to which Leuckart* has already called attention; during the movement of the wings, the different air-sacs of the tracheal system of the drone are filled with air, by which means these can act by pressure in the interior of the body of the bee, upon the neighbouring penis which is to be protruded.

After this single fecundation, a queen-bee can for a long time lay male or female eggs at will; for by the filling of her seminal receptacle with male semen she has acquired the power of producing female eggs, whilst before copulation and with an empty seminal capsule, and therefore in the virgin state, she can only lay male eggs. The second and most important point of the new theory of the reproduction of Bees, is the proposition established by Dzierzon, that,-All eggs which come to maturity in the two ovaries of a queen-bee are only of one and the same kind, which, when they are laid without coming in contact with the male semen, become developed into male Bees, but, on the contrary, when they are fertilized by male semen, produce female Bees.

Dzierzon therefore asserts that every egg laid without fertilization by a queen-bee produces a drone, and that every fertilized egg laid by her produces a worker or a queen, according: as the larva excluded therefrom is nourished with worker-food or royal-food.

This proposition of Dzierzon's theory necessarily made the greatest noise when it was first expressed, and requires above all to be submitted to the closest examination. Before I undertake this examination, I will only remark that one circumstance speaks à priori in favour of this proposition of Dzierzon, namely, that by adopting this proposition, every phænomenon, however remarkable, in the sexual existence of the Bees may be easily explained. But as a time-honoured physiological law is at once abolished by this proposition, namely, that an egg which is to be developed into a male or female individual must ahvays be

$$
\text { * See Bienenzeitung, 1855, p. } 201 .
$$


fertilized by the male semen, the affair appears of sufficient importance to be weighed and examined from all sides with the utmost care. I have taken the trouble upon myself, and tested Dzierzon's assertion with all the means at my command, by which I have convinced myself in the following way of its correctness.

In the first place, I may appeal to the fact, that it is a general occurrence amongst Insects, that the females, even when they have not copulated, deposit their mature eggs without fecundation; it is therefore nothing remarkable that a virgin queen deposits eggs. But we must be astonished that these egg's, although unfecundated, do not remain undeveloped; nay, what is more, that only drones, or male Bees, are produced from such eggs. As to the truth of this phænomenon, plenty of observations are adduced by the Apiarians, of which I bring forward, only as the most convincing example, the drone-productiveness of a virgin queen with imperfect wing's. Every observant and experienced Bee-keeper knows the ill consequences introduced by a queen-bee which has been excluded with crippled wings, and which has acquired the dominion of a bee-hive. She finds her.. self prevented from undertaking the wedding-flight, but follows the impulse to oviposition, and supplies worker-cells and dronecells indiscriminately with unfecundated eggs; these arrive at development, the larvæ excluded from them are provided with nourishment by the workers, they grow up, but all of the same size and the same nature; for they are all drone-larvæ, of which those which have grown in worker-cells cannot find room in these, and therefore the workers elevate their narrow cells by subsequent additions, so as to obtain room, and in this way produce misshapen combs, or combs with the so-called crooked brood (Buckelbrut).

A very interesting experiment was made by Berlepsch in order to confirm the drone-productiveness of a virgin queen. He contrived the exclusion of queens at the end of September 1854, and therefore at a time when there were no longer any males; he was lucky enough to keep one of them through the winter, and this produced clrone-offspring on the 2nd of March in the following year, furnishing 1500 cells with crooked brood*.

* See Bienenzeitung, 1855, No. 7. p. 76. 
That this drone-bearing queen had really remained a virgin was proved by the dissection, which Leuckart undertook at the request of Berlepsch*.

The true cause of such a drone-productiveness in a bee-hive, however, could only be detected by an apiarian as acute and endowed with such a distinguished porrer of observation as Dzierzon, whilst up to this time the unfortunate occurrence of an excess of drone-brood in a bee-hive has been quite differently and falsely understood by other Bee-keepers. They laid no stress upon the fact that such a hive only contained dronebrood, but they merely wondered that a hive governed by a queen with crippled wings contained any brood at all; and they endeavoured to explain this phænomenon by the supposition that this unexpected brood could only be produced by a fertilized queen. But as the queen from which this brood was derived had been found to be crippled in the wings, they erred in respect to the affair of copulation, and supposed that this crippled broodbearing queen was certainly fertilized, and that consequently the act of copulation was effected by the queen-bee within the hive. This erroneous conclusion of course brought in a number of other errors with regard to the signification of the particular Bee-individuals and their functions, by which a correct insight into the process of reproduction in the Bees must always have been disturbed.

Dzierzon alone did not allow himself to be diverted from the right path in his observations; he maintained that the female Bee can only return fertilized to her hive after the performance of her wedding-flight. He did not, however, content himself with this matter of experience; he went further in his rational way of investigating Bee-life; he examined more closely the egg-laying and drone-bearing queens, which according to his

* Leuckart found the state and contents of the seminal pouch of this queen to be exactly of the same nature (see Bienenzeitung, 1855, p. 128) as I had found in other virgin queens (see Germar's Zeitschrift für die Entomol. 1843, p. 374). The seminal receptacle in all these females never contained semenmasses with their characteristic spermatozoids, but only a limpid fluid, destitute of cells and granules, which is produced from the two appendicular glands of the seminal capsule, and, as I suppose, serves the purpose of keeping the semen transferred into the seminal capsule in a fresh state, and the spermatozoids active, and consequently capable of impregnation. 
observations were to be regarded as virgins; he tore away the apex of their abdomen, by which means he succeeded in getting a sight of the seminal receptacle, which in a female Bee is of the size of a pin's head. Dzierzon knew from experience, that a fertilized Bee in the normal state contains a milk-white seminal capsule, which when crushed gives issue to the milky seminal fluid. He knew that the empty seminal capsule of a newly excluded virgin queen is not milk-white, but limpid; and he convinced himself that in those drone-bearing queens with crippled wings the seminal receptacle was limpid and empty of semen, and consequently in the same state as the seminal capsule of a virgin queen. I have spoken with Dzierzon upon these observations; and as, from my own microscopical examination, I was well acquainted with the state of the sexual organs of virgin and fertilized queens, I was thus in a position to judge quite safly, from the description which Dzierzon gave me of his investigations, made without a microscope, that he had acquired perfectly correct notions as to the difference in the condition of the sexual organs of a virgin and fecundated female Bee, and therefore could not well have deceived himself in this respect*.

Moreover, I felt myself the less inclined to doubt the correctness of these observations of Dzierzon's just reported, as I could not but remember that, according to my own observations, the females of certain Psychida lay unfertilized eggs which are also developed, but, inversely, instead of males produce nothing but females. Dzierzon, however, by other observations furnished me with evidence in favour of his proposition, that drones alone are always produced from unfertilized Bees' eggs when they are developed, and that consequently, in order to obtain drone-brood, it is not necessary that the queen-bee should fertilize the eggs when laying them. As I have already mentioned (p. 39), it happens now and then in a bee-hive, especially when it has lost

* Berlepsch has also seen drone-production and crooked combs caused in the same way in bee-hives which were inhabited by a queen with crippled wings, which had consequently remained without copulation. See (in the Bienenzeitung, 1855, No.7.p.75) the important and interesting letter addressed to me by Berlepsch, in which he discusses the question, whether the dronceggs are fecundated. 
its queen, that individual workers lay eggs. This phænomenon has long been known to every experienced Bee-keeper; nay, it had already been observed, that only drones are developed from these eggs laid by workers*; but it is only from the attentive observer Dzierzon that we know why such egg-laying workers are always the parents of drones, or, in other words, why only drones are always developed from these eggs produced by workers, if they attain to development. This phænomenon stands in the closest connexion with the drone-productiveness of the virgin queen-bees already mentioned.

It was ascertained anatomically by Mademoiselle Jurine, that the worker-bees are nothing but female Bees whose sexual organs are aborted $\dagger$. By careful dissection the ovarian tubes not perfectly developed may be exhibited in all workers, connected with an undeveloped oviduct. I have already shown in the year 1843 , that in all workers, there is connected with this undeveloped oviduct, an appendage which perfectly represents the seminal receptacle of the queens. On this appendage I could discover the seminal duct, the seminal capsule, and the two appendicular glands, with their common efferent duct in the workers, but all these separate parts of the seminal receptacle were in a very undeveloped state $f$.

In what follows, I will endeavour to explain by what cause the ovarian tubes, which in the normally-formed workers always remain empty, may become exceptionally filled with eggs in certain workers. It is well known to Apiarians, that in hives which have suddenly lost their queen, the workers, if they wish to put themselves in possession of a new queen, select some worker-cells furnished with an egg or a young larva, and enlarge these into royal cells (queen's cradles), and that they do not then bring up the larvæ which are excluded from the eggs al-

* See Huber, Nouvelles Observations sur les Abeilles, p. 194. Even in the time of Aristotle similar observations had been made, as appears from these words:- "Dicunt indicio esse, quod fucorum foetus innascantur etiam, ubi reges absint, apum autem non innascantur." See Aristotelis de Animalibus Historice, lib. v. cap. 18 (ed. Schneider).

+ See the works of Huber and Ratzeburg already quoted (p. 3).

+ See my memoir upon the Receptaculum seminis of the female IIynenoptera. Germar's Zeitschrift für die Entomol. bil. iv. p. 375. 
ready laid in these former worker-cells, or which were found by them already excluded in such cells, with the ordinary workerfood, but furnish them with royal-food, as indeed all the eggs deposited by a fertilized queen in worker-cells are of one kind, namely female. But in order that the female sexual organs of such a larva may acquire their development, the larva must receive royal-food; if, on the contrary, the female sexual organs are to remain undeveloped for the advantage of the organs of the worker-bee, destined for work, this object is attained by the administration of worker-food. I leave it undecided in what the distinction between the worker- and royal-food consists; for the Apiarians have hitherto been at variance, as to whether the larræ of workers and queens received the same food, but the latter in greater quantity, or whether the queen's food differed from that of the workers not only in its quantity, but also in its quality. From Leuckart's recent investigations*, however, it appears that there really is a qualitative difference between the two kinds of food. The larvæ destined to become workers only receive the paste prepared by the workers in their digestive organs during the first days of their life, whilst in the latter days of their larval existence they are fed with pollen and honey; the queen-larvæ, on the contrary, are supplied with the above paste during their whole larval existence. Leuckart $†$ found the first traces of the internal genital organs in the female larva of six days old; it is exactly at this time that the change of food takes place in the worker-larra, which up to this period are nourished just like the queen-larvæ with the same paste. In this way we get an explanation of the circumstance which has been observed by most experienced Apiarians, that a female larva does not require the usage of a queen from its earliest period in order to become perfectly sexual, but that worker-larvæ, even several ( ix or seven) days old, may also be reared to queens, when their narrow cells are subsequently enlarged, and they are abundantly supplied with royal-paste, instead of with workers'-bread (pollen and honey).

If then it is certain that a worker-bee or a queen may be reared indifferently from every larva of a worker-cell derived

* See his Seebacher Studien in the Bienenzeitung, 1855, p. 209.

+ See Leuckart, loc. cit. supra, p. 210. 
from a fecundated queen, the case may probably occur in one bee-hive or another, that, by some confusion or disturbance in the regular distribution of the food, some of the royal-food falls to the lot of one or several worker-larva in the neighbourhood of a queen's-cell, into which royal-food is carried, by which their sexual organs are more or less developed. By this influence the development of the female genitalia may have been abnormally elevated in a worker, up to the power of laying true eggs*. Such egg-laying workers, however, always remain unfecunclated; they do not feel like perfect female Bees, and undertake no weddingflight; which, indeed, would be of no use to them, as the development of their copulative and fecundative organs has not kept pace with that of their ovaries and oviducts. The external sexual organs, as well as the seminal receptacle, remain abortive in these egg-laying workers, for which reason they are not in a condition to copulate and receive fertilizing semen. They will therefore only be able to lay unfecundated eggs, from which, if they actually arrive at development, only male Bees are produced, no matter whether they were laid in worker-cells or dronecells. The cause of the production of an excess of drones and crooked combs in a queenless hive is therefore, that as regards the nature of her deposited eggs, an egg-laying worker-bee is in exactly the same position as an egg-laying virgin queen,-both can only be the parents of drones.

Why the egg-laying workers can only lay unfertilized eggs, I have already explained in my letter to Baron von Berlepsch $\dagger$. At that time, indeed, I had not been enabled to dissect an egglaying worker-bee; so that the principal proof of the correctness

* Huber (Nouvelles Obs. sur les Abeilles, p. 202) was already aequainted with these occurrences in the bee-hive, and endearoured to explain them in the same way.

[Hunter's observations had not extended his knowledge beyond the following point:- "As soon as a few eombs are formed, the female Bee begins laying of eggs. As far as I have been able to observe, the queen is the only Bee that propagates, although it is asserted that the labourers do. Her first eggs in the season are those which produce labourers, then the males, and probably the queen. This is the progress in the Wasp, Hornet, Humblebee, \&c. However, it is asserted by Riem, that when a hive is deprived of a queen, labourers lay eggs."- "On Bees," Phil. Trans., 1792, p. 152.-1. O.]

† See Bienenzeitung, 1854, p. 231 . 
of my views as to the drone-productiveness of the workers still had to be obtained. This proof, Barun von Berlepsch has since furnished by dissecting a worker-bee which was laying droneeggs, and finding therein a small ovary with about eight pretty well developed eggs, but no seminal receptacle*. He did not content himself with this investigation of his own t, but in order to make the unbelieving Apiarians more inclined to accept the truth, he also called in the assistance of an entomotomist. At the request of Berlepsch, Leuckart of Giessen dissected at Seebach two workers taken in the act of laying eggs, of which, unfortunately, one individual, as Leuckart reported $\ddagger$, was no longer in good condition; but on the other hand, in the second individual he was able to prepare the sexual apparatus with its different parts in connexion, and to recognize the egg-laying Bee from its construction at the first glance. On the right side he found six, and on the left five, ovarian tubes, with single mature eggs. The single oviduct, as Leuckart said, was without appendages. In the first-mentioned egg-laying worker also, Leuckart could detect no seminal receptacle, although this structure is still distinctly recognizable in the queens, even when the other entrails are almost entirely dissolved by decomposition. I must here recall the fact that, as I have already mentioned (p. 57), the seminal receptacle is not entirely wanting in the workers, but that it remains undeveloped in them, and may be detected as a small appendage to the oviduct by a close microscopical examination. Leuckart overlooked this appendage in the egg-laying Bees examined by him, but has convinced himself, as he himself admits $\S$, by subsequent investigations, of the presence of the rudimentary seminal receptacle in worker-bees. At any rate, it appears from the investigations of Berlepsch and Leuckart, that, in the egg-laying workers dissected by them, the seminal receptacle was not present in the same degree of development as

* See Bienenzeitung, 1855, p. 78. Huber also (see his Nouvelles Observ. p. 192) dissected some of these egg-laying workers, and found in one individual eleven, and in the other four, nature eggs.

+ That Herr von Berlepsch has acquired the art of dissecting a Bee, I had the opportunity of convincing myself last summer with my own eyes, during my visit to Seebach, which will be mentioned further on.

$¥$ See Bienenzeitung, 1855, p. 203.

§ Bienenzeitung, loc. cit. p. 211. 
in the queen-bee, as in its perfectly developed state it is visible even to the naked eye, of the size of a pin's head, and consequently could not have escaped the notice of those two observers.

Another cause of drone-productiveness in a bee-hive may also be explained consistently by Dzierzon's theory. Thus in certain, but undoubtedly very rare cases, it happens that fertilized queens in advanced age towards the end of their vital activity become drone-bearing, after showing themselves to be normal up to that period as regards the production of drones, females, and workers; normal fertilized queens, therefore, in course of time lose the faculty of producing workers and females; the brood deposited by such old queens can only be reared to male bees, - certainly, according to Dzierzon's thcory, for the self-evident reason, that the store of semen in the seminal receptacle of a fertilized queen is gradually exhausted. As a queen only undertakes the wedding-flight once in her life, and fertilizes many thousands of eggs destined for the worker-cells for several consecutive years, with semen received by a single act of copulation*, although only one or two spermatozoids of the male semen are employed in the fecundation of one egg, yet the seminal mass will at last be used up, and at the same time the old queen will lose the faculty of laying the required number of fertilized eggs $\dagger$.

* According to a statement made to me by Dzierzon, a queen may acquire the power of laying fertilized eggs for five years, by a single normally executed copulation.

+ Upon this subject I may allow the experienced Apiarian Von Berlepsch to speak, as he has done in the Bienenzeitung (1855, p. 78) in the following words :- "It is a fact, that queens, when their fertility is on the decline, lay a greater or less number of drone-eggs in worker-cells amongst female eggs; nay, even with extremely fruitful queens, it by no means rarely happens, that individual drones escape from worker-cells in the midst of workers. How is this explicable except by Dzierzon's hypothesis, as even in this case the queens evidently wish to lay, not male, but female eggs? Leaning upon Dzierzon's hypothesis, I conjecture that in queens whose fertility is already on the wane, every egg can no longer be fertilized, because the receptacle is no longer sufficiently filled with semen, but that in queens which are still in the full power of their fertility, an egg which ought to be fertilized may now and then glide past without fecundation; a spermatozoon may not adhere, or may be lost again before it can penetrate through the micropyle into the yelk." 
From the circumstances hitherto described it will be evident, how a queen which has not been fertilized, or an old queen or egg-laying worker, must act injuriously upon a colony of Bees; they constantly cause confusion in a bee-hive, as they only produce lazy drones, and cannot, by the production of new workers, replace the loss of workers, to which every bee-hive is exposed. On the other hand, a colony of Bees which rejoices in the possession of a vigorous, fertilized queen will thrive well, as the drones, the workers, and the queens required for the emigration of young swarms, are produced by her at the right time, and in the proper proportions as to number, for which purpose the workers prepare and arrange the necessary drone-cells, workercells, and queen-cells.

Dzierzon's theory also includes the assertion that every normally organized and fertilized queen must at the same time possess the power of laying male or female eggs at will, that is to say, of leaving an egy unfertilized, or depositing it fecundated at will, when enyaged in laying her eggs.

The answer to the question, how a queen can know when she has to lay a male or female egg, will be, that instinct will tell her, and truly, at the moment when she pushes her abdomen into a wide drone-cell, or the narrow cell of a worker, for the purpose of laying an egg. The distinction of the wider and narrower cells will certainly be felt out by a normal queen with her abdomen, and by this sensation she will know, that she must fertilize the egg to be deposited in a narrow cell, whilst she has to lay down the egg without fecundation in a wide one. By the peculiar texture of an incomplete royal-cell too, a normal queen will be instinctively induced to fertilize the egg to be deposited in it. By this means Dzierzon might have explained that phænomenon in the bee-hive which has always excited astonishment as a wonderful mystery, namely, that faculty possessed by the normal queen of furnishing the drone-cells, worker-cells, and queen-cells of the combs, which are arranged in different number and order in every bee-hive, with the right eggrs. It would certainly still remain to be proved, from the organization and arrangement of the separate sections of the female sexual organs, that it really was possible for a fertilized queen, by the presence of decidedly voluntary muscles, to retain the 
semen in the seminal receptacle or evacuate it at will. From the investigations above referred to (p.4) which I made upon fertilized female insects, it appears that by the copulation of Insects the ovaries are not fecundated, but that the seminal receptacle is filled with semen, and that the fecundation of the egg only takes place during oviposition at the moment when the egg to be laid slips by the orifice of the seminal receptacle in the oviduct. With regard to this I may refer to those female insects, which, after the completion of copulation, survive their males in the autumn, hybernate with the ovaries imperfectly developed, and only lay fertilized eggs capable of development in the following spring, after their ovaries have become filled with mature eggs*. Such females, therefore, preserve the male semen received during copulation in their seminal receptacle, keep it fresh, probably by the aid of the secretion of the appendicular glands of the seminal capsule, and evacuate it at pleasure when required during the act of laying. For this purpose particular voluntary muscles do really exist; I have observed them in the vicinity of the exterior of the seminal capsule in many female Beetlest. In the immediate vicinity of the seminal receptacle of female Bees also, I have seen voluntary muscles, without, however, being able to state with certainty what definite functions they have to perform. From this, the possibility of a voluntary evacuation of semen from the seminal receptacle of fecundated female insects could certainly not be denied, especially as the voluntary deposition of male and female eggs by a queen-bee may be proved by the brood produced from her. After I had called the attention of Von Berlepsch to the existence of voluntary muscles at the seminal receptacle, he expressed himself upon this point in the following way $\ddagger$ :- "Probably the queen has the faculty of closing the orifice of the receptacle at pleasure, perhaps by the contraction of the whole vesicular membrane, or even that of removing and somewhat retracting the

* See upon this point my observations on hybernated fertilized female Wasps and Gnats, in Wiegmann's Archiv für Naturgeschichte, 1839, bul. i. p. 107, and in Germar's Zeitschrift für die Entomologie, bd. ii. 1840, p. 443. + See my investigations Ueber die Spermatozoen in den befruchteten InsektenWeibchen, in Müller's Archiv, 1837, p. 398. tab. 20. figs. 1 \& 2 g, \& p. 423.

$\ddagger$ Bienenzeitung, 1855, No. 7. p. 77 . 
whole receptacle sideways from the tube of the oviduct into which it opens, so that those eggs which she wishes to deposit. in male cells may glicle past untouched by the semen."

The power of a fertilized queen to lay male or female eggs at pleasure, may also be proved by the following experiment. In a Dzierzon hive we may, to a certain extent, compel a fertilized queen to lay male or female eggs. The construction of one of these hives permits the nature of the combs prepared in it by the workers to be closely inspected: if the workers of a hive furnished with a normal queen prepare too many drone-cells, which we may perhaps not wish to have, or if the hive requires more workers, we may remove the drone-combs, whose cells the queen would have shortly supplied with male, that is to say, unfertilized eggs, and instead of these suspend combs with empty worker-cells; the queen will furnish these combs also with eggs, and indeed, to correspond with the nature of the cells, with female or fertilized eggs, from which the workers may rear their like. In the summer we may induce the queens of populous hives to lay drone-eggs, if we suspend an empty drone-comb in the midst of the hive. From this it follows that the intelligent Bee-keeper has it in his own hands in what direction he will turn the activity of this or that colony of Bees, and that by suitable assistance he may prevent the disorganization and demoralization of a bee-hive.

Before I turn to the strictly scientific proofs which I have still to furnish, in order to give permanence to the view upon the reproduction of the Bees put forward by Dzierzon only as a hypothesis, and raise it to the rank of a theory, so that it may take its proper place in the history of animal development, I will here cite a few more empirical proofs, by which alone the correctness of Dzierzon's theory would be convincingly shown, if its importance did not require still more impressive facts for its establishment.

I must not omit to mention that Dzierzon himself, after calling a number of opponents into the field by the promulgation of his new theory, and after all possible imaginable objections had been raised from the most various sides against its correctness, began to doubt the perfect tenability of his theory. Notwithstanding that very recently Dzierzon expresses himself 
with peculiar reserve and caution upon certain points of his theory*, other experienced Apiarians still held firmly to it, as after it had once become perfectly familiar to them, by its assistance every occurrence in a bee-hive, however unexpected or apparently strange, was instantly understood by them.

Above all we must here mention Herr von Berlepsch, who has set himself the task of testing Dzierzon's theory in every direction, with his abundance of bee-hives. His establishment of Bees, which is most carefully attended to, and kept in the most exemplary order, also offers quite uniquely in its kind, by the disposition, arrangement and mass of its materials, the best and most certain opportunity of testing and answering those questions relating to Bee-life raised by Dzierzon.

The following extremely interesting experiments were made by Berlepsch, which must again convert Dzierzon himself, since he appears to have become a doubter of his own theory.

In May 1854 Berlepsch caught an old fertile queent, and confined her in a small queen's cage, in order to incorporate her with a new colony of Bees after its establishment. She was in the normal state, and up to that time had produced the necessary drones and workers. Berlepsch gives the following account of this queen :- "As I was closing the lid (of the queen's cage), which ran in a groove, I pinched the queen so strongly at the apex of the abdomen, that she contracted the whole abdomen like a bee that has been stung, and allowed it to drag after her. I thought at first that she was lost, but as she was still living an hour afterwards, and sitting again extended and quiet, I gave her back to her people. She laid, as before, thousands of eggs, but from all these nothing but drones were henceforward developed. If I had only dissected this queen as soon as I became aware of her drone-productiveness, I should at least have scen whether the (seminal) vesicle was still in existence and normally filled. But I delayed the dissection, and when at length I wished to undertake it, the queen was gone. This certainly very remarkable occurrence, which speaks loudly in favour of Dzierzon's hypothesis of the unfecundated state of all male eggs,

* See his Bienenfreund aus Schlesien, 1854, No. 8. p. 64.

$\dagger$ See the letter addressed to me by Berlepsch in the Bienenzeitung, 1855, No. 7.p. 78 . 
was communicated by me privately to President Busch for his opinion, as I could not then form any definite opinion for myself, not knowing with certainty that the vesicle is the receptaculum seminis, and the white slime (its contents) the sperma virile. Busch, however, was also unable to form an opinion; my servant Günther on the contrary thought, that perhaps the receptaculum had been crushed and destroyed. This, however, I regard as extremely improbable, as the crushing of the receptacle, which is generally very firm, between the soft surrounding parts of the body of the queen, without quickly leading to the death of the latter herself, is scarcely possible; I believe, therefore, that it was only that the organs which may act in opening and closing the orifice, or in retracting and advancing the receptacle, were lamed, stiffened," \&c.

If I am to express my opinion upon this interesting case, I suppose that by the pinching of the abdomen the seminal receptacle of the queen, filled with semen, was torn away from the oviduct at its opening point, by which the queen, thus injured, was no longer enabled to fertilize her eggs during deposition, and therefore could only lay unfertilized and consequently male eggs.

Berlepsch reports as follows* upon another experiment confirmatory of Dzierzon's principal point, which he made in consequence of studying J. Müller's Physiologie des Menschen: "Now only did I obtain a full conviction of the existence of the spermatozoa; and when I read in the above-mentioned work (bd. ii. p. 636) that high and low temperatures cause the movements of the spermatozoa to cease, I thought to myself: Now you have the complete explanation of Dzierzon's case †; and if it be true that in Apis mellifica the male eggs regularly develope themselves spontaneously into males, but are only converted into female eggs by the fecundation of the spermatozoa, every normally fruitful queen must cease to lay female eggs, from the moment when we succeed in rendering the spermatozoa motion-

* See his letter quoted above, p. 61.

+ Berlepsch here refers to the case communicated by Dzierzon (Bienenzeitung, 1854, p. 252. 2), that a queen which had been frozen for a long time, after being again brought to life by warmth, only laid male eggs, whilst previonsly she had also laid female eggs. 
less (killing them) without destroying the mother herself. At the end of June 1854, therefore, I took three very fruitful queens, imprisoned each of them in a queen's cage, went to Mühlhausen and placed the cages in the ice-cellar of an inn-keeper who was a friend of mine. There I left them for about thirty-six hours. The queens were of course completely benumbed, regularly covered with hoar frost, and when I returned with them to Seebach, I exposed them to the sun, which was just rising. For a long time none of them stirred; at last, towards seven o'clock, I observed movements of the feet in one of them. By means of a fine bit of wood I put a little honey upon her proboscis, and in ten or twelve minutes more, she had again returned to life. The two others on the contrary were dead. This appeared very remarkable to me, as even worker-bees, whose vitality, however, is very much weaker than that of the queens, generally survive such a short freezing; and the only reason I can find for it, is, that the temperature of the ice-cellar was too low, and therefore the queens were too much penetrated by the frost, if the circumstance that the queens were too heavy with eggs, and therefore less able than at other times to bear external injurious influences upon their bodies, may not have cooperated to produce death. I returned the revived queen to her people. She laid, as before, thousands of eggs, but from all of them only males were evolved. When I subsequently examined the semen, I found it less consistent and with a yellowish tinge."

From this extremely interesting experiment, it follows evidently that the male eggs of the Bees require no fertilization; the spermatozoids which this queen, exposed to such an intense cold, contained in her seminal receptacle, were certainly benumbed, and did not again become capable of movement after the thawing; so that therefore this queen could only have laid unfecundated eggs; for even if she had emptied the contents of her seminal receptacle over the eggs when laying them, in order to fertilize them, the numbed spermatozoids would have remained incapable of action.

A third empirical proof, by which the principal point of Dzierzon's theory of reproduction is supported, is furnished by the phænomena which may be observed in the production of mules amongst Bees. Attention has only been directed to the pro. 
duction of hybrid Bees at a very recent period, since the Italian race of Bees has been introduced into Germany by Dzierzon and Berlepsch. The so-called Italian Bees form no separate species, but must only be regarded as a variety of the Apis mellifica. These Italian Bees are distinguished at the first glance by the leather-yellow colour of their abdomen from the unicolorous blackish-brown German Bees. In the females and workers of the Italian race, the first, second and third abdominal segments appear of a rusty-yellow colour (colore rufo-ferrugineo) and margined with black; this black margin is very narrow on the first segment, broader on the second, and broadest on the third. The Italian drones have the middle of the hinder margin of the second, third and fourth, and often that of the fifth abdominal segment broadly rusty-yellow, by which the blackishbrown abdomen of these drones appears to be furnished on the back with from three to four rusty-brown transverse bands, of which the first is the broadest. The German drones, on the contrary, have the abdominal segments only narrowly margined with rusty-yellow*. According to the statements of Dzierzon

* This variety of Apis mellifica has already been for an extraordinary length of time indigenous in Italy and the South of Europe generally, for Virgil, and before him Aristotle, mention these rusty-yellow Bees in their descriptions of the œconomy of Bees. But unicolorous dark Bees must also have occurred constantly amongst the variegated or rusty-yellow spotted Bees, as both authors also speak of black Bees. In Aristotle's De Animalibus Historia, lib. v. cap. 18.2, we find,-" Regum autem genera duo; præstantior rufus : alter niger et varius magis." And further, lib. v. cap. 19. 1, "In genere apum præstantissima quæ parra, rotunda, varia; alterum genus est oblongum et vespæ (Anthrenæ) simile : tertium furen vocant: niger is, alvo lata. Quartus fuscus, omnium maximus, sine aculeo, ignavus." The verses of Virgil, in which (Georgicon, lib. iv. 91) he declares the variegated Bees to be more valuable than the black ones, are well known :-

"Alter erit maculis auro squalentibus ardens :

Nam duo sunt genera : hie melior, insignis et ore,

Et rutilis clarus squamis ; ille horridus alter

Desidia, latamque trahens inglorius alvum.

Ut binæ regum facies, ita corpora plebis.

Namque aliæ turpes horrent : ceu pulvere ab alto

Quum venit, et sicco terram spuit ore viator,

Aridus; elucent aliæ, et fulgore coruscant, Ardentes auro et paribus lita corpora guttis.

Hæc potior suboles." 
and Berlepsch, who have done especial service to the breeding and diffusion of the Italian Bees in Germany*, these goldenyellow Bees are not only more beautiful, but also more indus-

The statements also which Varro and Columella have made upon Bee-kecping, show that in Italy the gold-coloured or variegated Bees and the unicolorous blackish-brown Bees occur together. See Scriptorum rei rustica veterum latinorum (ed. Schneider), tom. i. p. 316. Varronis lib. iii. cap. 16 :- "Ut quidam dicunt, tria genera cum sint ducum in apibus, niger, rubcr, varius, ut Menecrates scribit duo, niger et varius : qui ita, melior; ut expediat mellario, cum duo sint eadem alvo, interficere nigrum, quem scit cum altero rege esse seditiosum, et corrumpere alvum, quod fuget, aut cum multitudine fugctur. De reliquis apibus optima est parva, varia, rotunda." Columella (lib. ix. cap. iii. op. cit. supra, tom. ii. P. i. p. 437) in the description of the Bees refers to the statements of Aristotle and Virgil, and says of the queens (cap. x. op. cit.p. 453), - "Sunt autem hi reges majores paulo et oblongi magis quam cæteræ apes, rectioribus cruribus, sel minus amplis pinnis, pulchri coloris et nitidi, levesque ac sine pilo, sine spiculo, nisi quis forte pleniorem quasi capillum, quem in ventre gerunt, aculeum putet, quo et ipso tamen ad nocendum non utuntur. Quidam etiam infusci atque hirsuti reperiuntur, quorum pro habitu damnabis ingenium." Therefore, even amongst the Romans, the variegated and golden-yellow Bees were more highly valued than the unicolorous blackish-brown race. That this rusty-yellow variety of the Honey-Bee is at present very widely diffused in Italy, appears from the descriptiou which Spinola (Insectorum Ligurice species nove aut rariores, tom. i. 1806, p. 35) has given of a Piedmontese Honey-bee. This Bee, furnished by Spinola with the name of Apis ligustica, agrees exactly, according to the description, with the rusty-yellow Bees recently introduced amongst us from Italy. Two individuals of the Apis ligustica, captured near Bellinzona and Sesto Calende on the Lago Maggiore, which I have been able to compare here with some Italian Bees of the true race bred in Seebach, I cannot recognize as a separate species, but only as a rusty-yellow variety of the Apis mellifica, the unicolorous dark form of which, according to Spinola's own statements (op. cit. p. 133), also occurs, although rarely, in Piedmont. The aurora-coloured Bees mentioned by Della Rocca (Traité complet sur les Abeilles, 1790, tom. ii. p. 142), and said to have been introduced into France from Holland or Flanders, may have belonged to the same Italian variety. The Egyptian Honey-bee also, described by Latreille (Annales du Hisséum, tom. v. 1804, p. 171) under the name of Apis fasciata, is probably nothing but this southern rusty-yellow variety of the Apis mellifica, especially as Latreille himself admits that this Egyptian hive-bee agreed exactly with a kind of Honey-bee taken near Genoa.

* Herr von Baldenstein of Graubündten has the merit of having first directed attention to the Italian Bees as an object adapted for experiment (see the Bienenzeitung, 1848, p. 26i). He had got an Italian bee-hive (on- 
trious and better-tempered than the German Bees. These latter properties are also the cause of the Italian Bees having become so much liked amongst us, and of so great a demand having recently arisen for them, so that Berlepsch found himself under the necessity of declaring publicly*, that "If the Italian good-tempered, industrious race, with its beautiful colour is to be kept pure and stereotyped, perhaps even improved Dzierzon and I must be left in peace for at least one summer."

It is a well-known fact, that by the crossing of different races of a species of animal, hybrid forms are produced, which unite in various ways certain characters of the two individuals of different races which were employed for the production of such race-hybrids. It was natural to suppose that in the Bees, the production of such race-hybrids must be combined with very

veyed over the mountains, in order to make use of the difference of colour which occurs between the rusty-yellow Italian Bees and the unicolorous dark Swiss and German Bees in his observations. In the following year he perceived that his Italian Bees degenerated in the mother-hive, a part of the new brood being quite Italian; whilst another part, on the contrary, appeared more or less like the Swiss Bees. From this phænomenon Baldenstein correctly concluded that the young Italian mother-bees must have copulated with a Swiss male bee, and certainly outside the hive : this production of hybrids would not have taken place if the young Italian queens had copulated in the mother-hive, where they met with a sufficiency of true Italian drones. Baldenstein further mentions (Bienenzeitung, 1851, p. 81) that those Italian motherbees, when he received them, were already four years old, and lived with him for three years more, therefore in all seven years; they always produced true Italian Bees, by which it is proved that these queens required no fresh copulation after the first one.

Incited by these interesting observations of Baldenstein's (see also the Bienenzeitung, 1853, p. 11), Dzierzon in February 1853 procured a bee-hive of the true Italian race (see Bienenzeitung, 1852, p. 204; and 1853, p. 40) from Madame Adele ron Prollius, a zealous Apiarian at Mira near Venice, from which stock at Carlsmarkt (in Silesia) the other German Bee-keepers might be provided with Italian Bees, by the observations of which such important scientific results have been obtained. For the various reports of the breeding of Italian Bees, see the Bienenzeitung for the years 1854 and 1855, and also the essay in that Journal for 1856, p. 1, in which Dzierzon discusses the question,-Is the Italian kind of Bee found by experience to be of the same importance for practice as for theory? And, above all, read the important communications of Berlepsch upon the Italian Bees (Bienenzeitung, 1856, p. 3).

* Bienenzeitung, 1856, p. 6 . 
peculiar modifications. If Dzierzon's theory proved correct, we might beforehand expect that by the copulation of a unicolorous blackish-brown German and a reddish-brown Italian Bee, the mixture of the two races would only be expressed in the hybrid females and workers; but not in the drones, which, as proceeding from unfecundated eggs, must remain purely German or purely Italian, according as the queen selected for the production of hybrids belonged to the German or Italian racc. In fact, the expectations of the Apiarians were not disappointed. It is true that in these crossings of the races many remarkable occurrences, such as also happen, contrary to expectation, in the crossing of our larger domestic animals, were still necessarily left unexplained. According to Berlepsch's observations*, 1. many Italian mothers produce partly black and partly variegated Bees under all circumstances, that is to say, whether they have been fecundated by an Italian or a German drone; 2. many Italian mothers produce only variegated Bees when they are fertilized by an Italian drone, but variegated and black ones mixed when the fertilization is effected by a German drone; and 3. many Italian mothers produce only variegated Bees under all circumstances, that is to say, whether they are fertilized by an Italian or German drone. Such true Italian queens, adds Berlepsch, produce Italian Bees from the very first, when fertilized by Italian drones; but, on the contrary, when fertilized by a German drone, they also produce German Bees at first, for a longer or shorter time.

Here I must insist upon the fact, that these statements of Von Berlepsch only refer to the production of workers and female Bees, but by no means to drones. He endeavoured to explain these surprising and singular facts, which reposed upon two years' experience, in the following manner. He refers to the existence of the appendicular gland so intimately connected with the seminal receptacle, to which $I$ had even in the year $1837 \dagger$ ascribed

* See the Bienenzeitung, 1856, p. 5 .

+ See my memoir Ueber die Spermatozoen in den befruchteten InsektenWeibchen (Müller's Archiv, 1837, p. 398). In this place I have said of the Glandula appendicularis,- "This organ probably serves for the secretion of a particular fluid, which is poured into the seminal receptacle and keeps the spermatozoa which remain here for a long time, alive." See also Germar's Zeitschrift für die Entomol. 1843, p. 368. 
the office of preserving by its secretion the seminal mass remaining for months in the seminal capsule, in a fresh state. Berlepsch, starting from this view, now thought, that the maternal liquor of the appendicular gland constantly penetrating (into the seminal receptacle) gradually permeates the spermatozoa to such an extent that their paternal elements are overpowered by the maternal ones. If the mother-bee is of pure Italian blood, none but variegated Bees must be produced from her fertilized eggs, as soon as the spermatozoa derived from a German drone are sufficiently permeated; but, on the contrary, if the mother be not purely Italian, black Bees will always remain. This conjecture, which I only quote here for the present as a conjecture, without saying anything for or against it, Berlepsch also endeavoured to support by the behaviour of a German queen, which, being fertilized by an Italian drone, produced last year variegated Bees amongst the black, but this year only black Bees.

In all these observations with reference to the propagation and multiplication of the Italian race of Bees, the brood of drones always turned out purely Italian, or purely German, even when crossings occurred between the German and Italian Bees, according as the queen subjected to crossing belonged to the Italian or German race. But in order to attain certainty with regard to these phænomena, the observations to be made for this purpose must be performed with the greatest care. The observations will have to be made only with individuals of perfectly pure race, which will not always be obtained with ease and certainty, since the breeding of the Italian swarms side by side with the German bee-hives is already carried on amongst us to a very great extent. How difficult it may be to find a perfectly genuine and pure queen for such experiments, is shown by the mixtures of the two races of Bees in question, observed by Berlepsch and already referred to. I can therefore lay no very great stress upon an observation which Dzierzon made upon an Italian queen, and which, as I have already indicated (p. 64), has made this cautious Apiarian doubtful of his own theory. This isolated case, in which, moreover, some circumstance might probably have remained unnoticed, cannot overthrow a proposition, the correctness of which has been confirmed in so striking a manner by a number of other observations. How Dzierzon was surprised by 
some such disturbing accident appears from his own statement, which I will give here literally, in order to show that Dzierzon is not one of those who cannot be led away from a preconceived opinion, whether it be right or wrong. His words* are as follow :-

"Continued observations of the hybrid hives also must be no less adapted to raise the veil more and more, to penetrate into the obscurity and finally bring the mysterious truth to light. If the drone-egg does not require fertilization, Italian mothers must always produce Italian drones, and German mothers German drones, even when they have been fertilized by drones of the other race. The Silesian Apiarian (Bienenfreund) possesses hybrid hives of both kinds, and did not permit any want of observations so far as the limited time enabled him to make them, but he met with new unsolvable riddles. The Italian hybridmothers have throughout completely confirmed the supposition and produced the most beautiful Italian drones, one almost more beautiful than the genuine stocks, the maternal stock itself. Of two German hybrid hives, one also produced only the ordinary black drones; the other the same, but unexpectedly amongst these a few appeared which glittered like gold, and were yellower than any single bee even in the genuine Italian hives. It certainly was possible that even here a beautiful Italian amongst the workers, of which a portion had the colour of the indigenous Bees, and another portion that of the Italians, might have laid some eggs, from which the few yellow drones might have been produced. Nevertheless the Silesian Apiarian is not particularly inclined to explain the phænomenon in this way, so as not to expose himself to the suspicion that only a predilection for his hypothesis led him to have recourse to this explanation, as in point of fact the deposition of eggs by worker-bees when a queen is present, is an exceptional occurrence of the rarest kind. Although the vesicle filled with semen does not implant the vital germ for the drone in the egg, may not a peculiar emanation from it nevertheless act in determining the kind and colour?"

Dzierzon is certainly in the wrong, when, for the sake of this one observation which disturbs him, and in order to explain it, he again calls in the aid of the long-overthrown hypothesis of the action of an aura seminalis. Von Berlepsch has taken the

* See the Bienenfreund aus Schlesien, No. 8, 1854, p. 63. 
trouble to invalidate this case detailed by Dzierzon, which is said to speak against his own theory. He very justly observes*, that in the preceding, Dzierzon has not established the fact that those few golden drones were actually produced by the queen, and not by a very fine egg-laying Italian worker (as the half of the workers in this hive consisted of these); for although the presence of an egg-laying worker together with a queen is a case of the very rarest occurrence, yet it can be proved that such exceptions do occur. Berlepsch also points out with reason, that Dzierzon was never perfectly certain on the point whether the queen, in whose hive he observed the remarkable yellow drones, was by birth of true German race, or produced from hybrid brood. Dzierzon himself adds the warning to the statement of his case $\dagger$, that in such observations great caution is necessary to avoid erroneous conclusions, as on such occasions we must be perfectly sure that the queen belongs by birth to the right race; for if she has been produced from hybrid brood, it is impossible for her to produce even pure drones, but she produces half-Italian and half-German drones. However, I regarded this doubt, which had been raised in Dzierzon with regard to his own theory and by his own observations, as a sufficient reason for getting further information from Herr von Berlepsch, who had obtained great experience in breeding Italian Bees for the last two years, with regard to the real truth in the production of hybrids taking place between Italian and German Bees. On the 2nd March of last year (1856) he replied to my questions put to him for this purpose, in the following manner. In the first place he referred to his observations already published in the Bienenzeitung $\ddagger$, where he says:- "All queens which are of a beautiful yellow externally only produce Italian drones, even when they produce partly Italian and partly German workers. A German mother, which was fertilized by an Italian drone, produced German and Italian workers, but only German drones. When on the contrary the mother is not of a fine yellow,- -when she has traces of black blood in her, the drones also come forth mixed, whether the mother be fertilized by a German or Italian male: of course because the

* See the Bienenzeitung, 1855, p. 79.

+ See the Bienenfreund aus Schlesien, ut cit. supra, p. 64.

\$ For the year 1856, p. 6 . 
males only take after the mother." To this Von Berlepsch added the following commentary in his letter:- "An Italian queen fortilized by a German drone, or a German queen by an Italian drone, constantly (only one exception has occurred to me) produces femaies (workers, queens) of three different colours : $a$. True Italians, that is to say, as yellow and banded as the female descendants of Italian queens, which were also fecundated by Italian drones; $b$. True Germans, and $c$. Mongrels. With many mother's, the Italian, and with many the German descendants predominate; but the mongrels, which, as regards colour, are intermediate be. tween the Germans and Italians, are always in the minority, and indeed in the greatest minority, for in many hives we rarely sec a mongrel, and in many none at all. Now as the queens are only workers, otherwise, that is to say, further developed, the same conditions occur in them also, and in hybrid mothers the colour of the royal descendants depends upon the egg. If the egg would have given a true Italian worker, it also furnishes a genuine Italian queen, \&c. The males without exception follow the mother as regards colour, and during the last summer I was unable to discover with hybrid mothers even a single male which resembled its father, in spite of the most careful observation and the closest examination."

After such important empirical facts, derived from the observation of a great number of productions of hybrid Bees, it must therefore be regarded as certain, that, in accordance with Dzierzon's theory, Bees of pure race are deprived of the power of producing hybrid drones.

Notwithstanding the experiments hitherto made in a practical way, by which Dzierzon's theory has acquired the right of asserting its justice, we cannot reject the demand that, by means of direct experiments, we must acquire the conviction that the drone-eggs require no fertilization for their development, whilst the same eggs, in order to furnish female or worker-bees, must be fecundated; for it is only by such strict scientific proofs that this new theory will acquire a firm and secure basis.

Since the production of fishes by the artificial fecundation of the eggs had been carried on of late years with such fortunate results, it was natural to think whether it was not possible to establish the correctness of Dzierzon's theory incontrovertibly 
by the artificial impregnation of the Bee's eggs. But this mode of proof was necessarily given up again at once as impracticable, for whoever submits the eggs of Bees to a close examination will immediately see that these eggs, from their extreme delicacy, are quite unfitted for such experiments. There would be no possibility of extracting mature eggs uninjured from the ovaries, in order to transfer them either unfecundated or artificially impregnated into cells, to be taken care of by the Bees; nor would these delicate eggs bear, without injury, the contact of a brush, however fine, moistened with the semen of male Bees, as would be required for artificial impregnation. Leuckart proposed* to employ eggs which had already been laid as drone-eggs in drone-cells, and to fertilize them artificially afterwards, in order in this way to decide the question, whether we should succeed by artificial impregnation in developing such eggs into workers or queens. He called attention, however, at the same time, to the difficulties which are opposed to the success of this experiment. Leuckart justly pointed out, that only very fresh and newly deposited drone-eggs should be made use of for artificial fecundation; for as soon as the thin albuminous coating, with which the eggs of insects are laid, becomes dry, which certainly takes place very quickly on deposited eggs, the semen employed for artificial impregnation can no longer penetrate through the pores of the egg-shell into the interior of the egg, by which means alone, as will be shown hereafter, the fertilization of the eggs of insects can be completed. From the importance of the object which would be attained by these experiments, difficult as they are to carry out, I heartily join in Leuckart's wish, that such experiments should be undertaken by many hands; perhaps one or other of the experimenters would be so fortunate, by the concurrence of several favourable accidents, as to attain what from Dzierzon's theory must $\grave{a}$ priori be expected as the result. From the preceding statements it follows that the artificial impregnation of Bees' eggs could not as yet be employed in favour of Dzierzon's theory.

Very different hopes were awakened in this respect, when we became acquainted with the existence and office of the micropyle

* See the Bienenzeitung, 1855, p. 206. 
of the eggs of insects. Since Leuckart and Meissner* have seen the spermatozoids penetrate the egg-shells through peculiar openings into the interior of the eggs of insects, we must say beforehand, that, if Dzierzon's theory proves to be correct, this process can only be observed in those eggs of Bees which are destined for the evolution of females or workers; and that in the

* I may be permitted, in reference to the discovery of this extremcly important and interesting phænomenon in the history of the fecundation of the eggs of animals, to mention the two names of Leuckart and Meissner; for according to epistolary communications upon this discovery, which I have in my hands from Meissner, I cannot but believe that both naturalists made their observations and discoveries on the eggs of insects independently of each other, and perhaps simultaneously. In a letter of the 8th of July 1854, which lies before me, Meissner writes from Göttingen :- " I I have continued my observations upon fecundation, and indeed amongst insects. The result is briefly as follows:In Diptera, Lepidoptera and Coleoptera, all the eggs have a micropyle at a definite spot, both in the chorion and vitelline membrane, and the spermatozoa penetrate from the seminal receptacle into the micropyle during the passage of the eggs through the vagina. In the Crustacea it is generally the same. I am still constantly occupied with investigations. In Musca vomitoria I found the still living spermatozoa in a mass, half in the yelk and half protruding from the micropyle. I am already busy with the elaboration of what I have found up to this time; drawings are prepared, and in a few days I think of sending you the memoir to which I have just referred in a supplement to my last paper, and as a continuation of the latter." (See the Zeitschrift für wissenschaftliche Zoologie, band vi. p. 263.) These observations of Meissner's were printed in the 2nd heft of the Zeitschrift für wiss. Zool. band vi. p. 272 (published on the 14th of September 1854). On the 17th of August 1854, at the Meeting of the Berlin Academy of Sciences, J. Miiller read an epistolary communication, of the 12th of August in the same year, from Professor Leuckart of Giessen, on the micropyle of the eggs of Insects (Bericht der Akad. der Wiss, zu Berlin, 1854, p. 494). This Report is published in separate monthly parts, of which the part for August had not yet reached me, when, on the 12 th of October 1854 , after my return from a vacation-journey of two months to Munich, I wrote my letter to Herr von Berlepsch. Consequently when in this letter (see Bienenzeitung, 1854, p. 230) I only mentioned Meissner's observations upon the micropyle of the eggs of Insects, I was still unacquainted with the investigations which Leuckart had made, as he himself admits, almost simultaneously, in the same department of eitomology. After this explanation, I think Leuckart has no longer any reason to reproach me with having ignored his investigations (see the Bienenzeitung, 1855, p. 129, and Leuckart's memoir Ueber die Mikropyle und den feinern Bau der Schalenhaut bei den Insekteneiern, in Müller's Archiv, 1855, p. 245). 
eggs which remain unfecundated, from which only drones are developed, no spermatozoids will penetrate through the micropyle, whilst the micropylar apparatus must exist in exactly the same degree of development in all these egg's, as all eggs are originally of one and the same kind and nature.

Those eggs of Bees which have to undergo a fertilization are fecundated at the moment when they slip past the orifice of the seminal duct of the receptacle within the oviduct (vagina). At this moment, as we may certainly suppose, some spermatozoa are pressed forth out of the efferent duct of the seminal receptacle, and these, in this way, by means of their mobility find an opportunity of penetrating through the micropylar apparatus into the interior of the egg. That the act of fecundation of the insectegg actually takes place at the point in the vagina just mentioned, was asserted by me in the year 1837, and confirmed by an observation which I made upon Musca vomitoria*. In Musca vomitoria and its allies, which had not yet completed the business of oviposition, or perhaps had been disturbed in it, and had not immediately met with another suitable place for the deposition of their eggs, the eggs occurring in the ovarian tubes and in the oviduct differed in the following extremely interesting manner. The egg, which was fixed between the vulva and the orifice of the seminal receptacle, had already begun to develope itself, and contained an embryo; whilst the egg found in the oviduct above the orifice of the seminal duct, which was perfectly equal in size with the preceding one, did not betray a trace of the commencement of the development of the embryo, any more than the eggs contained in the Fallopian tubes. In such female Flies the seminal receptacle always contained mobile spermatozoa. At that time we contented ourselves, in the explanation of the process of fecundation, with the supposition that the contact of the spermatozoids sufficed to incite the egg to development; more recently we have been compelled to drop this theory of contact, since we have been able to trace the penetration of the spermatozoids into the interior of the egg. The process of impregnation will now have to be more precisely conceived in the following manner :-The fecundation and capability

* See Müller's Archiv, 1837, p. 424. 
of development of the egg are not produced merely by the immediate contact of the semen with the egg, but the elementary constituents of the semen, the mobile seminal filaments, must actually slip into the interior of the egg, very probably to become destroyed here at first, to be dissolved and then mixed with the elementary constituents of the egg*. For this purpose the eggs of insects possess a micropylar apparatus, that is to say, one or more small apertures at one of the poles, through which the spermatozoids must get into the interior as far as the yelk of the egg, in order to complete the act of fecundation.

Leuckart was the first to set himself the task of ascertaining by direct observation, to what modifications the penetration of the spermatozoids through the micropylar apparatus of the eggs of the Bee would be subjected according to Dzierzon's theory. For this purpose he went to Seebach at the end of May last year, in order to be able to make use of the most abundant selection of the necessary objects for investigation. A better opportunity for such investigations could be presented to him nowhere else than in the immediate vicinity of the grand Beeestablishment at Seebach, in which however we must also take into account the disinterested liberality with which Herr von Berlepsch sacrificed his apiarian riches for the purposes of such physiological and anatomical investigations.

Leuckart's intention had already been announced by Berlepsch in the Bienenzeitung $\dagger$, and I was therefore extremely anxious to know what results Leuckart would obtain from these Seebach studies. These have been recently published by Leuckart in the above-mentioned Journal, from which $\ddagger$ I will here communicate the most important of the results.

Leuckart was of course obliged in the first place to turn his particular attention to the micropylar apparatus of the eggs of Bees, of which he gave the following description \$:- " $\mathrm{As}$ in the eggs of most insects, we distinguish in that of the Bees two

* The cases of true Parthenogenesis are, of course, to be understood as forming the exceptions to this rule.

+ For 1855, p. 82. 2.

$\$$ Bienenzeitung, 1855, Nos. 17 and 18 (published on the 30th of September), p. 99. Seebacher Studien.

§ See loc. cit. supra, p. 204. 2. 
membranes : an inner one, the so-called vitelline membrane, and an outer one, the egg-shell or the chorion. Both membranes are extremely thin and delicate : even the outer one, which otherwise (especially in those eggs which are deposited freely) is of considerable thickness and firmness; the vitelline membrane is structureless, whilst the chorion is covered with a delicate hexagonal lattice-rrork, as with a network, as far as the hinder (lower) flattened end of the egg which serves for its attachment. The micropylar apparatus lies at the anterior or superior pole of the egg, which is the last excluded during oviposition (and afterwards contains the head of the young larva). At this point, where the ridges of the chorionic network run together, we see a little fan-shaped figure (of about $\frac{1}{70}$ millim.) with about twelve rays. The rays of which the face is composed form the optical expression for the same number of micropylar canals, which run under the surface of the chorion. At their lower diverging ends these canals are open externally, whilst they open into the internal space of the eggs with their opposite extremities. The structure is exactly the same as in a number of other Hymenoptera (see Müller's Archiv, 1855, p. 236. taf. 11. figs. 12, 13), but with this distinction, that in this case the micropylar canals are most extraordinarily thin and delicate ; so that we can hardly convince ourselves with certainty of their real nature, and at the first glance might almost be inclined to regard the rays as ridges, such as also occur on the other parts of the chorion. The canals can hardly be more than $\frac{1}{500}$ millim. in diameter, certainly still sufficient to allow the passage of a seminal filament. During the last period of its stay in the ovary, the Bee's egg receives another external coating of an albuminous nature, which indeed is reduced to almost nothing on the anterior (superior) half, but gradually thickens posteriorly, and acquires a very considerable development at the flattened posterior (inferior) pole. This albuminous deposit serves for the attachment of the egg to the wall of the cell." Although I do not quite agree with this Leuckartian conception of the micropylar apparatus of the Bee's eggs, and I am especially compelled to regard the above-mentioned micropylar canals as something else, a detailed criticism of this representation of Leuckart's would lead me too far, and I therefore reserve this for another occasion, and will make use of the 
expression micropylar apparatus, without connecting therewith exactly the same idea as that which has been formed of it by Leuckart. The possibility of success in the above-mentioned (p. 76) artificial impregnation must depend, as Leuckart has very justly observed*, upon the thin albuminous coat of the eggs of Bees, for as soon as this albuminous coat has dried, which will certainly be the case within a few minutes of the deposition of the eggs in the waxen cells, the orifices of the micropylar apparatus will be plastered over with it, so that the seminal filaments will be prevented from penetrating into the interior of the egg.

Leuckart's statement alsot, that it is impossible, from the external condition of the Bee's egg, to arrive at any conclusion as to the sex of the Bee which is to be developed in it, is important, and I can fully confirm it.

Leuckart now hoped $\$$ "by the assistance of the microscope to ascertain the presence or absence of the seminal filaments upon the micropylar apparatus of freshly-deposited drone-eggs, and from this to draw a conclusion as to their fecundation or non-fecundation," as he knew "that in many cases it is not difficult to discover the seminal filaments singly or in strings, sometimes even in very considerable ones, in the albuminous layer covering the micropyle in freshly-laid eggs, and even to witness the act of slipping in through the micropyle." Unfortunately these hopes were not fulfilled, for Leuckart was compelled to admit that what he observed is not sufficient for the decision of the question, and only possesses some value in as far as Dzierzon's hypothesis is not directly contradicted by it.

Leuckart accounts for the failure of his design as follows : "The Bee is one of those insects which in fecundation only deposit very few seminal filaments, perhaps in many cases only a single one, upon their eggs. Important and significant as this circumstance is for the practical breeding of Bees, as only by it does it become possible that the queen, notwithstanding her immense fertility, can lay eggs for years together without exhausting the contents of her seminal receptacle-it is evident that it is equally unfavourable and unwelcome to the physio-

\footnotetext{
* See Seebacher Studien, loc. cit. supra, p. 206. 1.

† Loc. cit. p. 204. $1 .+$ + Loc. cit. p. 205. 1.
} 
logist who is in search of these filaments. To this we may further add, that in Bees' eggs the seminal filaments have not to penetrate through a thick albuminous layer before reaching the chorion, as is so frequently the case in other insects, but that they are deposited almost immediately upon the micropylar apparatus, and consequently can penetrate through its canals in a very short time. Lastly, if we consider the difficulties which are thrown in the way of the microscopic preparation of the Bee's egg by the great elasticity and the delicate texture of the chorion, we can hardly complain of an observer if he has not arrived at any satisfactory result in this case. I admit freely, that the investigation of the Bee's egg has been the most difficult of all the numerous investigations of this kind which I have undertaken during the last two summers."

By an unlucky chance, Leuckart whilst in Seebach found no opportunity of examining perfectly fresh-laid Bees' eggs, and at the time when Leuckart undertook these investigations, Von Berlepsch could by no means bring a queen to deposit her eggs. As the result of these Seebach studies, therefore, Leuckart could only furnish the editor of the Bienenzeitung with the following information:- "But you wish, then, to know to what my investigations have led in general? I reply that on two occasions only I met with some undoubted seminal filaments upon the micropyle of Bees' eggs; on one occasion a single filament, on the other several, four or five (and yet I have most carefully examined more than fifty Bees' eggs!). On both occasions it was upon worker-eggs that I found the seminal filaments. In drone-eggs I have never been able to distinguish a seminal filament, although I probably examined more droneeggs than worker-eggs, and amongst these such as had been laid at the utmost a quarter of an hour previously. You see, the result is doubtful. At all events it appears rather to speak in favour of, than against, Dzierzon; but I must again repeat that this appearance is possibly deceptive. In the interest of science, it would delight me exceedingly if other observers should be more fortunate than I have been in this respect."

For the satisfaction of Leuckart I may state here, that I have actually been more fortunate than him, and that I have seen what his eyes did not succeed in beholding. "Until" (so 
Leuckart closes his statements* relating to this subject), " either by experiment or by direct observation, the strict proof is obtained, that it is only the eggs of the female Bees that are impregnated, the question as to the causality of sex in the Bees remains an open one. Theoretical and other reasons may henceforth induce us either to support or oppose Dzicrzon, and we may increase the materials for the settlement of this question in an indirect way-its decision cannot possibly be brought about thereby." I have in fact been able to furnish by direct observation that evidence which must have been required by science as alone sufficient for the establishment of Dzierzon's theory. How far I may consider myself justified in this assertion, may be ascertained from the following statements:-

Although I knew that Leuckart was about to commence the above-mentioned investigations at Seebach, I had also long before undertaken to make similar investigations in the interest of science. Without knowing that Leuckart had already carried out his Seebach studies, and without being acquainted with the results which he had obtained from them, I also went to Seebach in the middle of August last year, because I was convinced that such investigations could only be undertaken by the aid of the abundant materials which would there stand at my command by the acknowledged complaisance of Herr von Berlepsch; I certainly entertained but little hope of attaining my end, as the season of the year was already too far advanced for such investigations. On the 21 st of August I was received by Herr von Berlepsch with the assurance, calculated to inspire very little courage, that I would probably find it difficult to meet with the necessary material, which I required for my investigations, at so late a period of the summer, and therefore that I had little chance of solving the problem before me, especially as Leuckart had been here at Whitsuntide, and therefore at a more favourable season of the year, but had departed without attaining his object, and confessed to Von Berlepsch that the questions relating to Dzierzon's theory could not be solved by the microscope on account of the very great difficulties which were to be overcome in the investigations to be made for that purpose. Nevertheless, 
I did not allow myself to be deterred from entering upon these investigations.

I was, however, actually astonished at the Bee-material which offered itself to me in Seebach, for the masses of Bee-colonies, as well as their judicious arrangement, so favourable to observations of every kind, surpassed all my expectations. I found 104 Dzierzon hives overflowing with honey and bees, destined for hybernation, and indeed distributed in various ways in eight places in a spacious orchard, amongst which I was particularly surprised at the pavilion containing 28 bee-hives, already frequently referred to in the Bienenzeitung. The distance of these eight Bee-establishments from each other was never more than 40 feet Rhenish. Amongst these hives there were nine genuine Italian colonies of Bees, the number of which might have been much greater, if, as Herr von Berlepsch asserted, seventy Italian mothers had not been furnished by him to other Bee-keepers, and the hives generally very much prejudiced by the various scientific experiments*. What has been of particular service to Von Berlepsch in his Bee-keeping is the assistance of his servant Günther, who, being endowed with excellent talents, has been instructed by Berlepsch himself in the mystery of Bee-keeping, and has approved himself in a distinguished manner $\dagger$.

I immediately set to work and examined a great number of female eggs, with which the great Bee-establishment of Herr von Berlepsch still furnished me in large quantities. It first occurred to me to make myself well acquainted with the organi-

$\uparrow$ What advantages may be obtained with the assistance of Dzierzon's hives, by assiduity and attention, and especially by the proper comprehension of the mode of life of Bees, will be seen by the dexterity with which Herr von Berlepsch manages his bee-hives even in a district which is poor in honey, as Seebach is described by himself (see Bienenzeitung, 1855, p. 3). According to Berlepsch's assertion, every one of his hives would be capable of giving him annually 30 pounds of honey and $1 \frac{1}{4}$ pound of wax, according to which 3120 pounds of honey and 130 pounds of wax, of the value of fully 400 dollars, might accrue to him from the whole 104 hives.

* This excellent assistant, who, as his master asserts, and I can testify, may be placed beside Huber's servant, François Burnens (see F. Huber, Nouvelles Observ.), has unfortunately been compelled to leave Seebach for the present, to pass his years of military service. 
zation of the eggs of Bees, so as to be exposed to no delusions or errors subsequently in seeking for the spermatozoids. It was only after I had exactly ascertained the structure of the eggenvelopes, the micropylar apparatus and the yelk, and practised myself in the preparation of the eggs of Bees, that I turned my attention to the spermatozoids, by whose presence or absence the principal decision was to be given. Above all, the most exact acquaintance was required with the individual ridges of the lattice-work of the egg-shell, which is composed of irregular hexagons, as well as with the folds of the vitelline membrane accidentally produced during examination, so as not to confound these things with spermatozoids which had become motionless.

After I had, in this way, made myself sufficiently familiar with the examination of the eggs of Bees, I had a comb brought to me at 10 o'clock in the morning of the 22 nd of August, containing female eggs, which had been deposited at the utmost an hour before. I might expect beforehand that no trace of spermatozoids would be recognizable externally in these eggs; I therefore directed all my attention to their contents, and hoped to discover the spermatozoids which had already penetrated through the micropyle, in the interior of the eggs. I soon convinced myself that there was no possibility of discovering the delicate seminal filaments between the granulo-vesicular yelk-masses; the linear object to be sought for was too subtile to be capable of discovery with certainty amongst the many mutually-crossing outlines of the yelk-vesicles. After various vain endeavours to render the interior of the Bee's egg accessible to the inquiring eye, I came at last to the idea of employing an artifice, which I had soon acquired by practice, and which allowed me to survey at least a portion of the inner space of the Bee's eggs with great clearness and tranquillity. I crushed a Bee's eg'g quite gently with a very thin glass-plate, and so that it was ruptured at its lower pole, opposite to the micropylar apparatus, and the yelk gradually flowed out at this spot, by which a clear empty space was produced at the upper pole within the micropylar apparatus, between the egg-envelopes and the yelk which was retiring downwards. I directed my attention very particularly to this empty space, which I saw slowly produced under the microscope during the effusion of the yelk. The production of such a pre- 
paration of course was not always successful, for sometimes the yelk flowed out of the ruptured envelopes, without the production of this empty space; the yelk also remained diffused in the upper part, and allowed of no certain judgment as to the presence or absence of seminal filaments. An error in crushing the egg, a little too much pressure upon it, or perhaps also a peculiar, less tenacious consistency of the yelk, probably caused the contents of the yelk to retire in every direction from the pressure, and therefore also to press upwards against the micropylar apparatus.

From the above-mentioned comb I examined ten eggs, which I succeeded in transferring uninjured from their cells upon an object-glass, which, from the delicacy of these eggs, is always a matter of difficulty. The result of their microscopic examination was as follows:-

The first female egg exhibited nothing remarkable. In the interior of the second egg, to my great delight, I observed three distinct, but motionless seminal filaments within the empty space which had been produced at the superior pole of the egg by the flowing out of the yelk through the inferior pole. In a third egg, after the same retirement of the yelk, I saw, in the superior space of the egg which had become empty, a single motionless seminal filament. In a fourth egg, I again observed three motionless seminal filaments at the same spot. A fifth egg, prepared in the same way, exhibited no seminal filaments. A sixth and a seventh had probably been too strongly squeezed in their preparation; the necessary empty space could not be produced in the interior of the egg at its superior pole, for which reason I regarded these preparations as of no use for investigation. In an eighth and ninth egg, fortunately prepared, I again saw a single motionless seminal filament in the superior empty space of the cavity of the egg. In the tenth egg the preparation was quite unsuccessful. This same comb with female eggs, after being carefully preserved in a room, was made use of for the continuation of these investigations at 8 o'clock in the morning of the 23rd of August. An eleventh egg was spoilt during the preparation; as was also a twelfth. A thirteenth egg was in an extremely interesting condition. After it had been for twentytwo hours out of the bee-hive and had been successfully pre- 
pared in the way above described, it exhibited two spermatozoids in the clear empty space between the egg-membranes and the yelk which had retired on the crushing of the egg. One of the seminal filaments performed very lively tortuous movements; the second filament was rigid, but adhered firmly to the other seminal filament, and was thus moved by its movements. These movements were first seen by me at about half-past eight, and were also observed by Von Berlepsch and Günther and by two other witnesses. Three minutes afterwards the seminal filament was still active. The preparation was then put by, and not again examined under the microscope for fifteen minutes. The movements of the first seminal filament had then ceased also, but both spermatozoids, although motionless, were still clearly distinguishable in the same spot. A fourteenth egg furnished no result, its preparation being unsuccessful. In a fifteenth, four distinct but motionless spermatozoids were discoverable in the space which had become empty during the preparation, between the envelopes and the retreating yelk.

On the same day, another comb with female eggs was removed from another bee-hive; it might at the utmost have been twelve hours old. The investigations continued with these eggs gave the following results. A sixteenth egg, the preparation of which turned out well, exhibited no seminal filaments in its interior. With the seventeenth egg the preparation was unsuccessful. An eighteenth egg contained three seminal filaments in the spot above mentioned; one of these was active. In the nineteenth and twentieth eggs the preparation was unsuccessful. The twenty-first contained two motionless seminal filaments, as did also the twenty-second. In the twenty-third egg, on the contrary, I could distinguish four motionless seminal filaments. With the twenty-fourth and twenty-fifth eggs the preparation was unsuccessful. The twenty-sixth and twenty-seventh again exhibited a single motionless filament, and the twenty-eighth two of them. The four following eggs all showed only a single motionless seminal filament. The examination of the thirtythird egg was again unsuccessful. The thirty-fourth and thirtyfifth eggs exhibited three motionless spermatozoids, and the thirty-sixth egg examined by me contained one active and three motionless seminal filaments. In the thirty-seventh and thirty- 
eighth eggs I could only perceive a motionless spermatozoid; in the thirty-ninth, fortieth and forty-first, on the contrary, I was able to discover two rigid spermatozoids.

On the 23rd of August a third comb furnished with female eggs was also employed for investigation, the eggs in which had only just been deposited. These eggs, however, did not show themselves so favourable to the above-described mode of investigation employed by me, because the yelk would not detach itself so easily from the vitelline membrane after the rupture of the envelopes; where I succeeded in producing the empty space between the envelopes of the egg and the yelk in these eggs, I often found it possible to discover spermatozoids in their interior. Not to weary the reader, I will only enumerate a portion of these investigations in their order:-The forty-third egg allowed a motionless seminal filament to be detected, sitting externally upon the micropylar apparatus. The forty-fourth and forty-fifth eggs furnished no results, from unsuccessful preparation. The examination of these was not repeated until seven o'clock in the morning of the 24th of August, when these deposited eggs were fifteen hours old. The forty-sixth egg contained several coiled but motionless spermatozoids. In the forty-seventh egg I was able to discover one motionless seminal filament; with the forty-eighth the preparation was unsuccessful, and with the forty-ninth and fiftieth I was obliged to leave it doubtful whether the object which might have been taken for a seminal filament, was such in reality. Both the fifty-first and fifty-second eggs allowed a motionless seminal filament to be clearly distinguished in the empty space, when the yeik had retracted itself clownwards from the micropylar apparatus by the rupture of the egg-shells.

If I sum up the observations just referred to, they furnish on the whole a very favourable result, considering the difficulties of the investigation, for I have also convinced myself, that these investigations of the egg of the Bee, are, as Leuckart has very justly asserted*, amongst the most difficult of all investigations of the kind. Amongst the fifty-two female Bee-eggs examined by me with the greatest care and conscientiousness, thirty furnished a positive result; that is to say, in thirty, I could prove

* Sec his Seebacher Studien in the Bienenzeitung, 1855, p. 205. 2. 
the existence of seminal filaments, in which movements could even be detected in three eggs. Of the other twenty-two eggs, twelve were unsuccessful in their preparation. At the same time I may also indicate particularly, that the observations with positive and negative results followed each other quite irregularly, but alternating at very short intervals, which probably was only dependent upon the favourable or unfavourable consequences of my preparation of the eggs employed for observation. If the question is to be raised, why Leuckart was not so fortunatc as to see what I have succeeded in seeing, I can make no other answer, but that probably the different method followed by us in our investigations, is to be blamed for Leuckart's want of success. Berlepsch informed me, that Leuckart did not examine the contents of the eggs by the careful compression of the Bee's egg, but that he confined himself to submitting the eggs in a perfectly uninjured state to an external examination.

It is certainly to my mode of investigation alone that I am indebted for the successful result of these observations, which were made with an excellent microscope of Kellner's. The careful rupture of the egg-membrane effected always by me, must prove an extremely important manipulation, for by this alone was it possible evidently to isolate the delicate seminal filaments which had penetrated into the cavity of the egg and become concealed by the yelk-mass, as, after penetrating into the egg they probably continue adhering for some time to the micropylar apparatus by their caudal extremity and remain behind, isolated in the upper empty portion of the cavity of the egg during the issue of the yelk-mass after the rupture of the membranes.

Above all things, however, it was of consequence to me that I should be able to examine male eggs (drone-eggs) also in exactly the same way, and Herr von Berlepsch actually procured me the means of doing this, although at first he had given me but little hope of obtaining such drone-eggs even in small number. It was truly a chef-d'œuvre to obtain drone-eggrs at so late a season: how my acute and experienced friend as it were compelled a queen to lay male eggs, the reader will be able to understand from what follows.

In No. 79 of his Bee-hives, Herr von Berlepsch possessed at 
queen, which he knew to be near her death, as her Bees had been constantly constructing royal-cells since the end of June, and the queen furnished these with eggs by which her loss might be replaced. Berlepsch, however, had not permitted the larvæ in these cells to come to exclusion, and thus this aged mother was still alive when I arrived at Seebach and inquired for drone-eggs. A little while before, this queen had laid droneeggs, but Berlepsch had destroyed this drone-brood also, as being useless. At last the workers had enough of it, and commenced no more cells. Berlepsch's object in this case was to determine how long the life of a queen might be prolonged artificially. When I came to Seebach, this queen was still laying single eggs. On the 21 st of August Günther received the charge to feed the hive, No.79, in the evening with fluid honey; the next evening (22nd of August) two combs with covered worker-brood, and between the two an empty drone-comb, were suspended in this hive. The following morning (23rd of August) there were twenty-seven drone-eggs in this drone-comb, and about sixty worker-eggs in open cells of the worker-combs. Berlepsch had carefully ascertained previously that not a single egg was present in the open cells of both the foreign worker-combs, when suspended in the experimental hive.

I examined these twenty-seven drone-eggs, which might have been about twelve hours old, and which agreed perfectly both in their appearance and organization with the female eggs, with the same care and by the same method with which I had treated the female eggs, and did not find one seminal filament in any single egg, either externaily or internally. I must also add, that only the seventh, thirteenth and twenty-third eggs were unsuccessfully prepared. In all the rest of these drone-eggs the yelk retreated slowly and completely from the upper pole of the egg-envelopes, after the bursting of the membranes; the desired empty clear space between the micropylar apparatus and the retreating yelk was produced in the interior of these eggs, so that if seminal filaments had been present in them, they certainly would not have escaped my searching and inquisitive eye. In order to be quite satisfied as to this remarkable negative result, and to obtain the full signification of it, several female eggs of the same queen which had furnished these drone-eggs, 
were examined for comparison; for the objection might certainly have been raised, that this queen might have laid nothing but barren eggs, as, being already weakened by age and near her death, she might have had no more spermatozoids in her seminal receptacle. Nevertheless, many of these eggs contained seminal filaments; they were the twenty-seven eggs already mentioned by me,-namely the sixteenth to the forty-second eggs.

To this result of my Seebach investigations, which proves the correctness of Dzierzon's theory by direct observations, I may also add that Herr von Berlepsch has lately informed me by letter, that this queen subsequently, after my departure from Seebach, also laid female eggs, from which workers were developed, but she herself only died on the 19th September, 1855. 


\section{TRUE PARTHENOGENESIS IN THE SILK-WORM MOTH.}

Having proved the occurrence of a true Parthenogenesis, combined with such extremely remarkable phænomena, in the Bees, I return once more to the Lepidoptera, in order to refer to the Bombyx Mori, regarding which notices were constantly coming to my ears, sometimes here, sometimes there, which indicated the Silk-worm Moth as one which sometimes laid eggs capable of development sine concubitu. The older statements relating to this appeared to me at first to be equally unfounded with the other cases of Parthenogenesis in the moths elucidated by me (p. 12).

How little inclination there was even formerly to believe in any such Parthenogenesis of the Silk-worm, appears from a letter written by Constans de Castellet, General Inspector of the Silk establishments in the kingdom of Sardinia, in which* he reports that eleven female silk-worm moths which had just crept out of the cocoon were observed by him, which, in their virgin state, deposited eggs, from which caterpillars and cocoons were reared. Castellet, who had not expected this, and wished to be sure that he had not deceived himself, repeated the experiment, imprisoned the female cocoons in different rooms, and convinced himself of the thriving of the silk-worms which he afterwards obtained from the virgin brood deposited by these moths. He made a report upon this case to Réaumur, who however answered him shortly: ex nihilo nihil fit, and doubted the correctness of the facts. By such an answer from so distinguished a naturalist, Castellet found himself induced to investigate the affair closely once more, and believed that he had at last got at the reason of it, by thinking that he saw that silk-worms in his breeding-place, which were already very near the time for spinning themselves up, had copulated. He thought he observed,

* See the letter referred to: Sulle uova de' vermi da seta fecondate senza l'accoppiamento delle farfalle, in the Opuscoli Scelti sulle scienze et sulle arti, tom. xriii. 1795, p. 242. 
namely, that some caterpillars had united quickly and others more slowly for a moment with the hinder extremity of their body. What is to be thought of this observed union, may be left to every one who is acquainted with the anatomical construction of an adult caterpillar, as regards the generative organs.

A later notice relating to this subject is the assertion of Herold, according to which*, amongst the eggs of an unfertilized silk-worm moth, some here and there are said to have passed wholly or partially through the same changes which are observed in eggs fertilized by true copulation, whilst most of the eggs remained unaltered. Herold, in his representation of the development of the egg of the silk-worm moth, even distinguishes between fotuses developed from fecundated and unfecundated eggs, of which the former make their escape, whilst the latter always remain in the egg-shell and die $\dagger$. Although Herold has not stated more precisely what precautions he took to attain the certain conviction that the brood produced from unfertilized eggs was actually derived from virgin females, I nevertheless looked upon the above assertion of Herold with less distrust than upon the before-mentioned examples of supposed Parthenogenesis derived from the history of reproduction of the moths, as with the very sluggish silk-worm moths, which do not fly about in the open air, there could be much less probability of the occurrence of a secret and unobserved copulation.

It is remarkable that this spontaneous evolution of the embryo in unfecundated eggs, mentioned by Herold, an observation which might easily be repeated upon the Silk-worms, which are so widely diffused, has hitherto escaped the attention of physiologists. Herold was the first who furnished an exact and detailed description of those changes which may be detected with the lens in a determinate sequence in different silk-worm eggrs developing themselves without fecundation. He described first of all, upon the sixth plate of his Disquisitiones $\neq$, the consecutive

* Disquisitiones de animalium vertebris carentium in ovo formatione. Fasc. ii. 1838, tab. 7.

+ Loc. cit. tab. 7. fig. 31 .

† Disquisitiones, \&c. Fasc. ii. 1838. 
changes which the silk-worm eggs rendered capable of development by a fertile copulation undergo with regard to their outline, colour and contents, from the moment of deposition up to that condition in which they remain more or less unaltered through the whole winter. He also points out particularly that the coloured membrane which makes its appearance below the egg-shell, and which passes through a definite change of colour, upon which the changes of colour of the whole egg depend, is certainly in general a sure indication that fecundation has taken place, but especially the most certain token that the eggrs are actually capable of development. Herold at the same time figures an embryo* as it occurs in the middle of winter in the fecundated egg of a silk-worm moth, after the egg has completed its change of colour within the first eight or ten days after deposition. On the seventh plate Herold represents the consecutive changes "in regard to outline, colour and contents undergone, in the first weeks after deposition, up to the state in which they remain more or less unaltered throughout the winter, by many of the eggs which the female silk-worm moth lays by herself, without copulation with the male, and many of which are nevertheless endowed in different degrees with the power of development almost like those which are actually rendered fertile by the assistance of the male." He could distinguish various degrees of the faculty of development of unfertilized eggs, which manifested themselves by infinite differences in the disposition, number, form, and strength of colour, of the coloured parts of the egg. In some of these unfecundated eggs the faculty of development had attained such a high degree, that Herold was able to extract a fœetus from one of them in the middle of wintert. According to Herold's further statements, however, embryos were not found in all unfertilized eggs capable of development which he examined in the winter, and he had also never seen young caterpillars creep out of unfertilized eggs, as they had previously ceased to live.

Moreover, Malpighi was already acquainted with the distinction between fertilized and unfertilized silk-worm eggs. This distinguished naturalist long since knew, what has been left un-

* Loc. cit. sup. tab. 6. fig. 15.

† Lor. cit. tab. 7. fig. 19. 
noticed by a later physiological school, namely that the ovaries were not fertilized by copulation, but that after a copulation each individual ready-formed egg is fertilized for itself. This appears distinctly from his published investigations. Malpighi saw* that the sulphur-yellow eggs taken out of the ovaries of a fecundated silk-worm moth behaved exactly like unfecundated eggs; whilst an egg, which he discovered in the vagina of this moth, acquired a violet colour in course of time, and consequently showed itself to be fecundated. Malpighi derived this influence from the contents of the bursa copulatrix, the signification of which and its opening into the vagina he knew $\dagger$. The seminal receptacle also certainly had not escaped his searching glance, but he had not comprehended its importance $\ddagger$. Pallas $\S$ also referred to the changes of colour undergone by the fertilized eggs of the silk-worm moth and other moths after they have been laid. He observed that the eggs of a Papilio Iris, which he cut out of the body of a fecundated female, did not change their grass-green colour, whilst the deposited eggs of a fertilized butterfly of this kind became yellowish-green; and from this he drew the correct conclusion, that the fertilization of these eggs only takes place during their passage through the vagina of the mother (see Note on Hunter's experiments at p. 52).

Exactly at the time when I had become acquainted with the Parthenogenesis of the Psychida, my attention was called from several sides to the occurrence of Parthenogenesis in Bomby $x$ Mori, in such a way that I could not avoid a closer examination of the phænomena here referred to.

The principal incitement to this was furnished by the following statement, made in the year 1851 by P. de' Filippi $\|$ :- "Je me bornerai à citer un cas singulier, qui m'a été raconté tout dernièrement par un célèbre entomologiste anglais, M. John Curtis, à son passage par Turin, d'une chrysalide isolée de Bombyx polyphemus qu'il avait reçue de l'Amérique, et de laquelle

* Marc. Malpighii Dissertatio de Bombyce, Londini, 1669, p. 82.

† Op. cit. p. 81. tab. 12. fig. 1. K, I, M.

¥ Op. cit. p. 80. tab. 12. fig. 1. E, F, G, H.

\$ See his Anmerkungen über einige Besonderheiten an Insekten, in the Stralsunder Magazin, band i. st. 3. 1768, p. 240.

It See Annales des Sciences Naturelles, Zoologie, tom. v. 1851, p. 297. 
naquit une femelle dont tous les œufs se développèrent. Je crois que la même chose a lieu quelquefois dans les femelles de Bomby $x$ Mori, quoique tout à fait séparées des mâles."

This notice brought to my mind several other communications as to the possibility of a Parthenogenesis in Bombyx Mori, upon which I was now compelled to lay the greater stress, after Filippi, whom I knew to be a thoroughly cautious physiologist, had come forward as a witness to the correctness of this assertiun. I recalled to mind a statement of Mögling's*, that the female moth of Bombyx Mori lays 350 to 480 eggs, which might be capable of development although the female was not fertilized by any male + . Here also evidently belongs that observation of Boursier's which was reported some years ago in the Comptes Rendus $\ddagger$, that a female silk-worm moth, which had not copulated with a male, had been exposed by Boursier, sometimes to the sun and sometimes to the shade, during which treatment the moth laid many eggs, of which those which were laid in the sun furnished caterpillars. Although no one will attribute the fertilization of the eggs in the preceding case, as Boursier has done, to the influence of the light and heat of the sun, we shall not be able to help seeing a Parthenogenesis in this phænomenon. I applied to Filippi himself, in order to obtain something further from him as to the propagation of the silk-worm moth sine concubitu, as he lives in a country in which the cultivation of silk is carried on to a very great extent; and he certainly could easily have collected observations upon the subject in question. Filippi wrote to me on the 29th of May 1852, as follows:- "Quant aux œufs de Bombyx Mori éclos sans fécondation préalable, voilà ce que je pourrais ajouter. C'est en 1850 que j'ai eu occasion d'observer une chose pareille avec des vers à soie de la variété dite parmi nous des trevoltini (c'est à dire qui peuvent être élevés trois fois dans l'année). Aussi M. Griseri, qui s'occupe beaucoup de l'éducation des vers à soie, a trouvé que plusieurs

* See his book upon the Silk-worm, 1847, p. 89.

$\uparrow$ Mögling here refers to the Notices sur les Educations des Vers à Soie faites en 1840 par $M$. Robinet, which have not yet come under my notice.

‡ See Comptes Rendus, No. 12. 1847, or Notizen von Schleiden und Froriep, band v. 1848, p. 20. 
œufs déposés par des femelles vierges se développent. Plusieurs cultivateurs de vers à soie m'ont assurés la même chose."

These various notices upon Bombyx Mori, taken together with the observation made by Curtis upon an isolated American Bombyx, in which no mistake could certainly have slipped in, as well as an observation reported by Johnston*, according to which caterpillars were evolved from the eggs taken out of the body, and therefore unfecundated, of a Smerinthus ocellatus killed two days previously,--all these statements confirmed me in supposing the existence of a Parthenogenesis also in Bomby $x$ Mori, although I have denied this amongst the Lepidoptera, with the exception of particular Psychida. I am not on this account to be accused of an inconsistency, for the examples previously (p. 12) cited by me, which were supposed to speak in favour of the Parthenogenesis of the moths, can never be admitted as credible evidence, for the reasons already asserted.

In order to obtain personal observations upon the Parthenogenesis in Bombyx Mori, I put myself in communication with various silk-worm breeders in Breslau and Munich; from these also I received the serious assurance, that caterpillars were not unfrequently developed from the eggs laid by unfertilized female silkworm moths. By the courtesy of the manufacturer, Herr Steiner of Breslau, an extensive silk-breeding establishment was put at my disposal, with the aid of which I was enabled to inform myself upon various interesting processes in the oviposition and development of the Silk-worm. First of all, in the summer of 1852, I procured a sufficient number of silk cocoons of male and female sex. After their exclusion, I allowed several pairs to copulate, whilst I strictly separated and watched another quantity of female moths, which I had already recognized as such in the cocoons. Both the fertilized females and those which had remained unfertilized, of which I had selected seven for observation, deposited a great quantity of eggs, all of which I submitted to a very careful inspection. Almost all the eggs laid by the

* See the Zoologist, 1848, p. 2269, and also Schleiden und Froriep's Notizen, 1849, band viii. p. 170. I presuppose that in the present case the eggs were taken out of the ovaries, and not out of the ovidnct, becanse otherwise, after any preliminary copulation, such eggs might have been fecundated from the seminal receptacle. 
fecundated silk-worm moths changed in a few days in the wellknown manner, their sulphur-yellow colour gradually becoming converted into dark yellow, then into orange, red, violet, and lastly into bluish or slaty-grey, which had often taken place even on the third day after laying. The eggs at the same time remained tense, and bore in their middle the flat impression which is also well known. In this bluish colour, as the token of their vitality, I got these eggs through the winter, and in the following spring they furnished me with a great number of caterpillars. I must here observe, that the previously mentioned change of colour of the Silk-worm's egg does not arise from a commencement of the development of the embryo, but is only the consequence of a peculiar alteration of the yelk, which at first shines through the colourless, dimly transparent egg-shell with a sulphur-yellow colour, and subsequently with the various changes of colour. A few of the eggs laid by the fecundated moths retained their sulphuryellow colour, and at last shrivelled up. These certainly lost their vitality, because from some cause the penetration of seminal filaments into the micropyle was prevented, and thus the fecundation of these eggs was not attained*.

To the eggs obtained from the seven virgin silk-worm moths I directed particular attention from the first, as I was very curious to see whether a Parthenogenesis would not be observable at least in some individuals of these eggs. I was therefore much surprised when I perceived exactly the same well-known change of colour which took place in the fertilized eggs soon after their deposition, in a far greater number of these eggs than I could have hoped, but in the unfecundated eggs it occurred much later and more slowly. From some of these virgin silk-worm moths I had obtained thirty to forty, from others only about ten to twenty eggs, the colour of which slowly altered in comparison with the other eggs which had remained yellow, and which gradually shrivelled up. But this change of colour did not go on quite constantly in the same way as in the fertilized eggs. Only a few unfertilized eggs passed through the entire alteration of colour to the slate-grey; most of them remained stationary at earlier steps of the change, only became reddish or violet, and even shrivelled up at last like the pale yellow unfertilized eggs,

[* This is an insufficient cause, from Siebold's own showing.-W. S. D.] 
but still a month or two later than these. Unfortunately I had not the satisfaction of obtaining caterpillars from the unfertilized eggs which had become slate-grey and remained tense, and which I had preserved with care through the winter, for they also shrivelled and dried up entirely, when the next spring had arrived. The same thing happened to me with a great number of slate-grey and tense eggs, possessing exactly the appearance of fecundated eggs, which were handed over to me by Herr Steiner with the assurance that they were laid by virgin silkworm moths. After several months I found these eggs entirely shrivelled, without my obtaining a single larva from them.

In the year 1854, Herr Schmid of Eichstadt, who has occupied himself for eighteen years with the breeding of silk-worms, sent me a quantity of bluish-grey, tense silk-worm eggs, which, according to his assurance, were derived from virgin moths. From all these eggs caterpillars were actually developed. It was of much consequence to me to rear the moths from these caterpillars, in order to see whether only a single sex, either only males or only females, would make their appearance from all these unfertilized egg's which had arrived at development, as in the case of the Psychida and that of the Bees.

Although I could state no definite motive by which I might have been induced to expect beforehand the evolution of male moths from the unfertilized eggs of the Silk-worm moth, I must admit that, although without any definite ground, I cherished the expectation that those silk-worms evolved from unfertilized eggs would furnish nothing but male moths. For my justification, I might certainly cite that remarkable notice of Carlier's already mentioned (p. 20), which Lacordaire has communicated in the following words*:- "Cet observateur a obtenu, sans accouplement, trois générations du Liparis dispar, dont la dernière ne donna que des mâles, ce qui mit naturellement fin à l'expérience." Although, as already remarked, this short notice contains no proof that the observation therein communicated was made with the necessary care and exactitude, it now acquires a peculiar importance, since Dzierzon's theory has proved to be correct. Even in the year 1852, I urged upon Dzierzon himsclf

* See Lacordaire, Introduction, \&c. tom. ii. p. 38.3. 
the idea, whether the property possessed by certain fermale silkworm moths, of laying eggs capable of development without fecundation, might not be of use in furnishing aid to his theory of the reproduction of the Bees, by means of exact trials and experiments. In consequence of this, Dzierzon recommended such experiments to the silk-worm breeders*.

Experiments were hereupon made in this direction in several quarters with silk-worms, but up to this time the reports furnished of them are still imperfect $\dagger$. A notice contained in these Reports from Dr. Kipp, who had obtained a quantity of eggs, and from all these caterpillars, from a Poplar Hawk-moth (Sphinx Populi) which had been excluded and kept shut up in a box, speaks against Dzierzon's theory, as both male and female moths were reared from these caterpillars $\ddagger$. I myself took the greatest trouble with the rearing of those young caterpillars which I had obtained from the unfecundated silk-worm eggs given to me by Herr Schmid, and of fifteen caterpillars which grew large, I brought twelve individuals to spin up. The different forms of the cocoons at once allowed me to judge that different sexes would be excluded from them, and subsequently seven male and five female moths actually crept out of these twelve cocoons. To convince myself whether these moths produced by Parthenogenesis were really sexually mature and capable of propagation, I did not prevent them from copulating, which they did immediately on making their escape. After the performance of copulation the females deposited a number of eggs, which showed themselves to possess vitality, and in the following year furnished the same number of caterpillars. Schmid, who had supplied me from his store of unfecundated, vitalizable silk-worm eggs, made similar experiments at the same time with the rest of the eggs which he had retained, and obtained the same result as myself. That Schmid performed his experiments with great care and with the necessary caution, appears from the report which he sent me on the subject, from which I extract the following as worthy of notice. In the year 1853, Schmid captured twenty-four silk-

* See the Bienenzeitung, 1853, p. 103.

$\dagger$ Bienenzeitung, 1853, pp. 144 \& 175, and 1855, p. 26.

†Bienenzeitung, 1853, p. 175. 2. 
worm moths immediately on their creeping out of the cocoon, in order to keep them securely in the virgin state ; they were isolated, and found themselves compelled, about the 2 nd to the 4 th day, to deposit their eggs unfecundated. Some hundreds of these eggs, which were at first of a sulphur-yellow colour, gradually acquired the well-known slate-grey tint, and both in this coloration and in the rest of their appearance exactly resembled the eggs of fertilized silk-worm moths. As they thus showed themselves to be capable of life, they were carefully preserved by Schmid through the winter, and in the spring of 1854, when the mulberry hedges began to get green, they were brought out of their winter dwelling-place, in order to dispose them for complete development in a suitably warmed place. The exclusion of the caterpillars took place immediately from 274 unfertilized eggs laid by 24 virgin silk-worm moths; in 270 other unfertilized eggs of the same moths the caterpillars were dead before exclusion. As regards the number of vitalizable eggs, which Schmid obtained from 24 unfecundated silk-worm moths, he remarks that none of these unfecundated moths laid entirely vitalizable eggs, but that sometimes vitalizable, sometimes unvitalizable eggs were deposited in irregular alternation one after the other by one and the same individual, as immediately after four or ten or fifteen vitalizable eggs, the same number or more or less of unvitalizable eggs might be counted; sometimes $\in$ ntire masses of eggs were laid, amongst which only one, tro, three or four vitalizable eggs were to be observed. Schmid, like myself, had also made the observation that all the eggs laid by fertilized female silkworm moths are not, without exception, vitalizable, but that in rare cases single unvitalizable eggs (unfecundated) occur amongst the other vitalizable (fecundated) eggs. Several of the abovementioned virgin female silk-worm moths, howerer, laid nothing but unvitalizable eggs. Of the 274 silk-worms obtained from unfecundated eggs, Schmid could only keep fifteen alive, in consequence of the extremely unfavourable conditions of temperature which occurred in the spring of 1854 ; he fared no better in the same spring with the silk-worms obtained from fertilized eggs. Of these fifteen silk-worms twelve were brought to spin up, and these furnished eleven moths, amongst which there were seven males and four females. Schmid allowed three of thesc female 
moths tolay eggs withoutfertilization, but all the eggs deposited by these three virgin female silk-worm moths remained light yellow, and soon shrivelled, so that they had not been vitalizable. The fourth of these females paired with one of the seven males which had been reared from unfertilized eggs; the eggs laid by this female after the act of copulation were all, with the exception of sixteen, vitalizable, and furnished very fine silk-rorms in the year 1855. Of the six other male silk-worm moths, two were employed to copulate with other ordinary females; these latter also laid throughout vitalizable egg's, from which very fine silk-worms were produced. In the year 1854 Schmid again selected twenty-four female cocoons of silk-worms, which were all separated singly and strictly inspected. From these, twenty-three females and one male escaped; the latter was removed immediately after his exclusion. The twenty-three females deposited their eggs more or less irregularly in their solitary cells, and amongst these there were only twenty-one vitalizable eggs, the whole of which were laid by four of these moths; all the rest of the eggs had for the most part remained pale yellow, or had become reddish-brown, and then shrivelled. Unfortunately, in the following year, 1855, the breeding of the caterpillars from these twenty-one eggs was unsuccessful; the twenty-one caterpillars had been perfectly developed in them, but their exclusion must have been retarded on account of want of nourishment, by which they died within the egg-shell. In the year 1855, Schmid selected eight female cocoons, which rere separated and watched with equal care and anxiety. They furnished eight female moths, of which seven individuals deposited their whole store of eggs in the virgin state, whilst the eighth female, notwithstanding the greatest exertion, could not deposit even a single egg. Schmid sent me the entire harvest of eggs from these moths upon seven strips of paper; there may have been about 3600 eggs ; each of the strips of paper contained about 512 eggs, which these moths had attached during deposition. On the first strip all the eggs were still tense, and furnished with the flat central depression; forty of them had retained their light yellow colour, five had acquired a slate-grey colour, and all the rest appeared reddishbrown. The second strip of paper bore eighteen bright yellow and seven slate-grey eggs; all the rest were of a reddish-brown 
colour. The whole of the eggs appeared tense, and with a flat depression in the middle; eight reddish-brown eggs presented themselves completely shrivelled. On the third strip there was only a single light yellow egg, all the rest had acquired a reddishbrown colour. None of these eggs were dried and shrivelled, but the central depression was very strongly sunken in a great many of them, so that it may be supposed that these eggs will very soon become dried up. The fourth strip of paper contained only four slate-grey eggs; all the rest of its eggs possessed a reddish-brown colour; only eleven of them were completely shrivelled, but others were more or less approaching desiccation. On the fifth strip of paper, I could count thirty light yellow, tense eggs ; all the rest were of a reddish-brown colour, and only a few of these were dried up; on the sixth strip there were only four light yellow, tense eggs; all the rest were reddish-brown, amongst which only a few had undergone complete desiccation instead of the central depression. The seventh strip of paper possessed only reddish-brown eggs, of which fourteen were already completely shrivelled; but many others, to judge from the deeply sunken central depression, were on the way to desiccation. Whether caterpillars will actually be developed from the above-mentioned sixteen slate-grey eggs, which are still apparently vitalizable, must be left to time to show.

If these investigations and experiments have as yet furnished no definite result, the reason of this certainly is, that they have not been repeated often enough; at any rate Parthenogenesis is now firmly established in Bomby $x$ Mori, but nevertheless the history of the reproduction of this moth merits to be further traced in this direction, as this precise object offers so many suitable and convenient data for observations and experiments. 


\section{CONCLUDING REMARKS.}

Parthenogenesis, as it has been demonstrated by me in Pysche Helix, and Solenobia clathrella and lichenella, in Bombyx Mori and Apis mellifica, certainly occurs more generally in the insect world, than the fer examples hitherto discovered lead us to suppose. This Parthenogenesis undoubtedly occurs in accordance with determinate laws, which have hitherto entirely eluded our observation. In Nature, definite objects are probably attained by Parthenogenesis, which we can only comprehend, when we shall have learnt to know the life and actions of Insects in general more exactly, than is at present the case. What an important signification Parthenogenesis has amongst the Bees, will be seen at once, for without Parthenogenesis the whole complicated œconomy of the Bees, as prescribed by Nature, could not exist at all. It is therefore now a task for the entomologists, to search for further examples of Parthenogenesis in the insect world. There are already indications enough, as to how and where this remarkable mode of propagation is to be sought after amongst Insects. From certain observations which we find scattered in various entomological works, it appears, that here and there Parthenogenesis drrells unsuspected, and that by it the history of the reproduction of many insects is veiled in mysterious obscurity.

Here belongs, amongst others, the statement of Léon Dufour, that he has never obtained a male of Diplolepis galla tinctoric**

* See Léon Dufour, Recherches anatomiques et physiologiques sur les Orthoptères, les Hyménoptères et les Neuroptères, in Mémoires présentés par divers savants à l'Acad. Roy. des Sci. de l'Institut de France, tom. vii. 184], p. 527. Here we find, "C'est un fait fort singulier, mais bien positif, que, sur plus de deux cents individus du Diplolepis galla tinctoria, nés dans mon laboratoire de galles renfermées en bocaux, je n'ai rencontré que des femelles. Malgré toute mon ardeur à rechercher des mâles, dont la dissection m'intéressait au suprême degré, je n'ai jamais pu en rencontrer un seul. Ce qui stimulait encore davantage mon désir extrême d'étudier ce dernier sexe, c'est que les nombreuses femelles soumises à mon scalpel étaient dans un état arancé de 
Of the genus Cynips, twenty-eight specics are known, which, according to Hartig's statement, are all destitute of males*. Hartig has inspected nine or ten thousand of Cynips divisa, and three or four thousand of Cynips folii, and found no single male amongst them. Hartig has even collected C'ynips folii for eight years, and has never obtained anything but females of this Gallfly; at the same time he saw these female Cynipida proceed to the deposition of their eggs immediately after their issuing from the galls.

The reproduction occurring amongst certain of the lower Crustacea, which it has been attempted to refer to Alternation of Generations and nurse-formation, may also turn out on closer investigation as true Parthenogenesis. As is well known, the genus Apus amongst the Phyllopoda only presents females; Zaddach indeed has supposed that he discovered male individuals in Apus cancriformis $\dagger$, but I have called this statement in question, on account of the want of positive proof $\ddagger$. Of the Phyllopodous Limnadia gigas also, no male has yet been discovered $\S$. In Daphnia too, it appears not to be nurses but female individuals which perform the business of reproduction by Parthenogenesis; for Liévin, who has compared with each other, female Daphnice taken in copulation, and others which were independently prolific, could not find the least distinction between the two kinds $\|$. Of Polyphemus oculus, we as yet only know female individuals $\%$.

fécondation, quoique je procédasse à leur vivisection immédiatement après leur sortie de la galle."

* See Zweiter Nachtrag zur Naturgeschichte der Gallwespen in Germar's Zeitschrift für die Entomol. band iv. 1843, p. 397.

+ See Zaddach, De Apodis cancriformis anatome, 1841, p. 53.

¥ See my Lehrbuch der vergleichenden Anatomie der wirbellosen Thiere, 1848 , p. 495 . note 8 .

\$ See Brongniart, Mémoire sur la Limnadia, in Mémoires du Muséum d'Histoire Naturelle, tom. vi. 1820, p. 89 . " "Il reste un point très curieux ì éclaircir dans l'histoire de ces animaux, c'est leur mode de génération ; il est en effet fort remarquable que sur près de mille individus que nous avons rus à Fontainebleau, tous portoient des œufs soit sur le dos, soit dans le corps."

\| See Liévin, Die Branchiopoden der Danziger Gegend, in the Neuesten Schriften der Naturforschenden Gesellschaft in Danzig, band iv. heft. 2., 184ㄴ, p. 26.

T See Jurine, Histoire des Honocles qui se troucent aux environs de Gentre. 
Amongst the Mollusca also, phænomena occur, which indicate the possibility of a Parthenogenesis; thus amongst others, Vogt was able to observe the commencement of development in the eggs of a female Firola laid without fertilization, namely a segmentation of the yelk proceeding to a certain extent*.

From these intimations, it appears that reproduction by Parthenogenesis is far from being sufficiently exhausted by my investigations, and is still capable of receiving many an addition. Even now, however, we may declare that the hitherto generally admitted proposition of the fecundation theory, that the development of the eggs can only take place under the influence of the male semen, has suffered an unexpected blow by Parthenogenesis. It has indeed been attempted to avoid this, and hold on to the old important proposition of the theory of fecundation, by supposing that in many cases a single fecundation may act through several generations; but much is not gained by this new proposition, as by it many of the phænomena occurring with Parthenogenesis can by no means be explained. On the other hand, it may appear too bold to assign already to Parthenogenesis a definite position in the history of the reproduction of animals, before it is thoroughly explored to a much greater extent and in all directions. Victor Carus has attempted to bring Parthenogenesis into combination with the care of the brood (Neomelie), and has established the proposition $t$ : the female form must be fertilized, and indeed by the male form, but for the development of the latter $\ddagger$ no repetition of the fecundation is required,the male germ developes itself in the manner of a bud or nurse. This proposition, however, cannot be applied to all the cases of Parthenogenesis cited by me; properly speaking, it only suits the Bees; in the other cases only females are evolved from the unfecundated germs, and in Bombyx Mori, females and males simultaneously in indefinite numerical proportions.

In Psyche Helix, Solenobia clathrella and lichenella, in oppo-

1820, p. 146. “Quoique je ue doute pas qu'il n'y ait des mâles dans cette espèce comme dans les précédentes, je dois annoncer que dans le petit uombre d'individus que j'ai trouvés, ou élevés, je n'en ai reconnu aucun."

* See Vogt's Bilder aus dem Thierleben, 1852, p. 217.

† System der thierischen Morphologie, 1853, p. 280.

$\ddagger$ Op. cit. p. 57 . 
sition to the Bees, the females after copulation will probably deposit those fertilized eggs from which only males are developed.

Hence it may happen that here and there in the open air we find the male and female individuals living together by themselves, and separate from each other. With this, the observation of Zinke stands in perfect accordance*, that many Sacbearers only occur in separate sexes during their larva and pupa state, and that where one sex is met with, the other may be sought for in vain. A communication made to me by letter by Heyden may also find an explanation by this: Heyden observed in the genus Coccus that the males live in company separated from the females, until they are perfectly developed.

The male individuals in the larva state probably lead quite a different mode of life in Psyche Helix, and might in consequence have hitherto escaped the observation of those entomologists who hoped to find the caterpillars of the males of Psyche Helix as Sac-bearers with a convoluted dwelling. For these assertions of mine, which are only expressed as suppositions, a support may be found in an observation which was made by Léon Dufour. From a particular gall, he always reared nothing but female individuals of the Hymenopterous insect Stomoctea, but was much astonished when he obtained nothing but males of this insect from the pupa of a Tenthredot.

* See Germar's Magazin der Entomologie, i. 1813, p. 31.

$\uparrow$ See Léon Dufour, Recherches, \&·c., p. 528. To the observation that he had only been able to obtain females of Diplolepis galle tinctoria, he adds the following interesting remark:-_'J'engage les entomologistes à nous faire connaître le mâle de cette espèce, la plus grande de nos contrées. Il serait bien curieux de constater si les œufs qui ne produisent que des mâles sont tous pondus dans une espèce de galle, et ceux des femelles dans une autre. Je puis eiter à l'appui de cette question un fait digne de remarque. En juin 1833 j'obtins, des galles de la Scrophulaire canine, produites par l'Eulophus Verbasci, un petit Hyménoptère du groupe des Cynipsaires, appartenant à un genre nouveau, que ses mandibules pectinées m'ont fait appeler provisoirement Stomoctea. Il en naquit au moins une einquantaine d'individus, mais tous, sans exception, femelles. En juin 1834, je ne fus peu surpris de voir éclore d'une chrysalide de Tenthredo, placée dans un verre clos, une quarantaine d'individus de la même espèce de Stomoctea, tous du sexe maseulin. Que n'avons-nous pas à apprendre encore sur les Hyménoptères gallicoles et pupivores, soit quant à la détermination des espèces, soit quant à leur genre de vie et aux merveilles de leur organisation viscérale !" 
From these fragmentary statements it will be seen what a wide field still stands open for the investigation of Parthenogenesis, accompanied as it is by such extremely peculiar phænomena; in no case, however, will this portion of the history of the reproduction of animals, enveloped as it is in so much obscurity, allow itself to be quickly and easily cleared up; for, as regards Psyche Helix, for example, the entomologist desirous of knowledge, and seeking after the males of this moth, must arm himself with patience in order to arrive at the goal; for if, in this case, which is probable, Parthenogenesis has its hand in the affair through several generations, as only a single generation of this moth, the male of which has been sought in vain for the last seven years, is produced annually, we should still have to wait some years before a male generation at last makes its appearance, and reveals the mystery interwoven with this moth. 


\section{EXPLANATION OF THE FIGURES.}

Fig. 1. Caterpillar-sac of Psyche Helix, Sieb., seen from the side. Natural size. $b$, opening which has been left by an escaped Chalcis.

Fig. 2. The same sac with the caterpillar; $a$, aperture which the caterpillar always leaves in this spot during the enlargement of its sac.

Fig. 3. The same sac seen from above; $a$, as in the preceding figure.

Fig. 4. Full-grown caterpillar of Psyche Helix. Natural size.

Fig. 5. Female pupa of Psyche Helix. Natural size.

Fig. 6. Sac with caterpillar of Psyche Helix. Enlarged. a, as in fig. 2 .

Fig. 7. Caterpillar of Psyche Helix. Enlarged.

Fig. 8. Maggot-like female of Psyche Helix. Natural size.

Fig. 9. The same enlarged. By transmitted light the urinary ressels appear black under the microscope, and not yellowish-white as by direct light. $c$, head; $d$, a portion of the urinary vessels shining through the integument.

Figs. 10, 11, 12. Three figures copied from Réaumur's Mémoires, tom. iii. pl. 15. figs. 20-22. Enlarged sacs of Psyche Helix, which Bazin found upon sandstone in the vicinity of the Hermitage d'Estampes.

Fig. 13. Chalcis nigra, Koll., from Psyche Helix. Natural size.

Fig. 14. The same insect enlarged.

Fig. 15. Caterpillar-sac of Psyche Planorbis, Sieb., seen from above. Natural size. $a$, spot in which the walls of the sac are deficient, as in fig. 2 . 
Fig. 16. The same sac from the side.

Fig. 17. The same sac seen from below; $a$, as in fig. 15 .

Figs. 18, 19. Sac of Helicopsyche Shuttleworthi, Bremi. Natural size.

Fig. 20. The same sac seen from above, enlarged.

Fig. 21. The same seen from the side, enlarged.

Fig. 22. The same seen from beneath, enlarged.

Figs. 23, 24. Valvata arenifera, enlarged and copied from Lea.

Supplementary Observation.-At my last visit to Zurich I saw in Bremi's collection the cases of a third larger species of Helicopsyche, which Bremi obtained from Shuttleworth and has named Helicopsyche Colombiensis. These cases come from Puerto-Caballo; they have a transverse diameter of $1 \frac{8}{10}$ lin. and a height of $1 \frac{2}{10}$ lin. Rhenish, and are manufactured out of comparatively very coarse, rusty-brown stones. With regard to Helicopsyche Shuttleworthi, Bremi informed me, that the cases of this Phryganidous insect hare now been found also on the Lake of Genera. 
SIEBOLD On PARTHENOGENESIS.

(3)
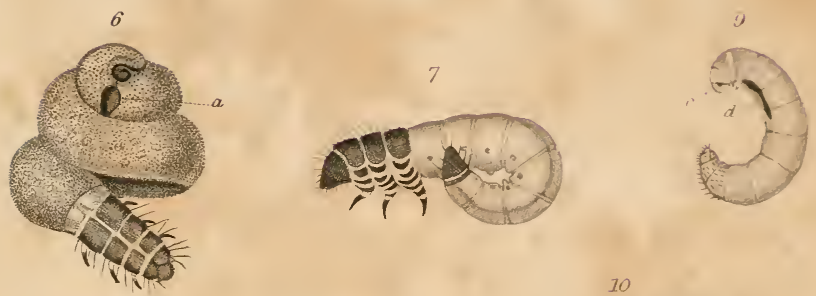

$\frac{13}{4}$

10
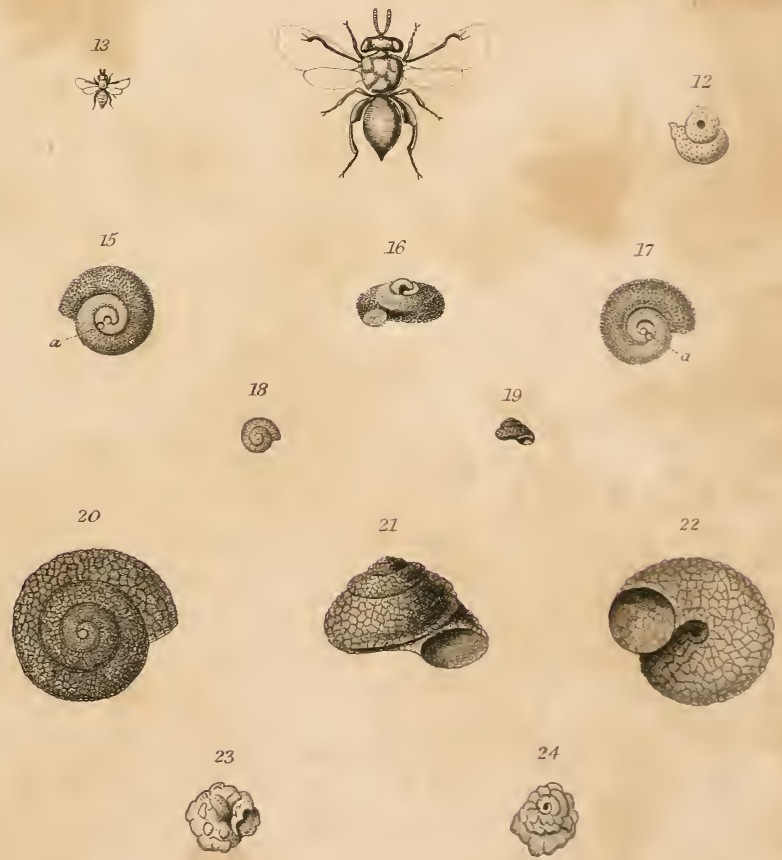
$\sqrt{2}+x^{2}$ 


\section{AN ALPHABETICAL LIST OF BOOKS PUBLISHED BY Mr. VAN VOORST.}

Many of the works are freely illustrated, and of some a few large-paper copies have been printed.

ACCENTUATED LIST OF BRITISII LEPIDOPTERA Ero, 5. ADAMS, BAIKIE, AND BARRON. MANUAL OF NATUR.II, for the Use of Travellers. Post Sro, 12s.

ADAMS, H. AND A. GENERA OF RECENT MOLLUSCA. I. 850, Plates plain, $£ \pm 10 s$; Royal 8 ro, the figures of the Animals Cof ed, $£$.

AIKIN. ILLUSTRATIONS OF ARTS AND MANUFACTURE Fools. $\because$ cap 8 ro, $8 s$.

ANSTED. ELEMENTARY COURSE OF GEOLOGY, MINERALOGY, and Physical Geography. Second Edition, post 8ro, 12.s.

SCENERY, SCIENCE, AND ART. 8ro, 10s.6 $d$.

- THE ANCIENT WORLD. Second Edition, post 8ro, 10s, Gd.

- THE GEOLOGIST'S TEXTBOOK. Foolseap 8ro, 3s. $6 d$.

- THE GOLD-SEEKER'S MANUAL. Foolseap \&ro, 3s. $6 \pi$.

ATTFIELD. AN INTRODUCTION TO PIARMACELTICAL CHEMISTRY. Post 8ro, 10s. $6 d$.

BABINGTON. FLORA OF CAMBRIDGESHIRE. 12mo, with a Map, is. $10 s, 6 d$.

BAILY. CHARACTERISTIC FIGURES OF BRITISII FOSSILS. Part 1, 8ro, plain, 5s.; Coloured, $7 s$.

BAPTISMAL FONTS. A Series of 125 Engravings, with Deseriptions. Sro, $£ 11 s$.

BATE AND WESTWOOD. BRITISII SESSILE-EYED CRLSTACEA. Parts 1-20, 8ro, 22s. 6d.; Royal, 5s, each.

BEALE. NATURAL HISTORY OF THE SPERM-WIIALE. Post Sro, 12.

BECK. THE ACIROMATIC MICROSCOPE. Royal Ero, $21 s$. 
BEDDOME. FERNS OF BRITISH INDIA. 4to, rol. i., $£ 4$. . FERNS OF SOUTHERN INDIA. 4to, in Parts, $£ 610 s$.

BELL. BRITISH REPTILES. Second Edition, 8vo, $12 s$.

- BRITISH STALK-EYED CRUSTACEA. 8vo, $25 s$.

- AND TOMES. BRITISH QUADRUPEDS. In the press.

BENNETT. GATHERINGS OF A NATURALIST IN AUSTRALASIA. 8ro, $21 s$.

BLOOMFIELD'S FARMER'S BOY, AND OTHER POEMS. With Illustrations, foolscap 8vo, $7 s .6 d$; l large paper, $15 s$.

BOCCIUS. PRODUCTION AND MANAGEMENT OF FISH IN FRESII Waters. 8 vo, $5 s$.

BONAPARTE. GEOGRAPHICAL AND COMPARATIVE LIST OF THE Birds of Europe and North America. 8ro, $5 s$.

BOWDITCH. ON COAL-GAS. 8ro, 2s. $6 d$.

BREWER. FLORA OF SURREY. 12mo, with Two Maps, $7 s .6 d$.

BRIGHTWELL. LIFE OF LINNEUS. Foolscap 8 ro, $3 s .6 d$.

BRODRICK. FALCONERS' FATOURITES. Folio, $£ 22 s$.

BULLER. LETTERS FRON ABROAD. Post 8 ro, $7 \mathrm{~s}$.

BURTON. FALCONRY IN THE VALLEY OF THE INDLS. Post 8 ro, $6 s$. CATALOGUE OF BRITISH VERTEBRATE ANIMALS. 8ro, sewed, $2 s 6 d$. CHURCH. LABORATORY-GUIDE FOR STUDENTS OF AGRICULtural Chemistry. Post 8 ro, $4 s .6 d$.

CLARK. BRITISH MARINE TESTACEOUS MOLLUSCA. 8ro, 15.s.

- LETTERS HOME, FROM SPAIN, ALGERIA, AND BRAZIL. sro, $7 \mathrm{~s} .6 \mathrm{~d}$.

CLAUSIUS. THE MECHATICAL THEORY OF HEAT. Translated by Hirst. 8ro, 15 s.

CLERIIONT, LORD. GUIDE TO THE QUADRUPEDS ATD REPtiles of Europe. Post 8ro, $7 \mathrm{~s}$.

COUCH. ILLUSTRATIONS OF INSTINCT. Post 8 ro, $8 s, 6 d$.

CRICHTON. A NATURALIST'S RAMBLE TO THE ORCADES. Foolscap 8ro, $4 s$.

CUMMING. THE ISLE OF MAN. Post 8ro, 12s.6d.

CUPS AND THEIR CUSTOMS. Post 8 ro, $2 s, 6 d$.

CURRENCY (THE) UNDER THE ACT OF 1844. 8 ro, $6 s$.

DALLAS. ELEMENTS OF ENTOMOLOGY. Post 8 ro, $8 \mathrm{~s} .6 \mathrm{~d}$.

DICKSON. THE UNITY OF THE PHISICAL SCIENCES. Post 8 ro, $4 s$.

DODSLEY. ECONOMY OF HUMAN LIFE. 12 Plates, 18mo, 5 . 
DOMESTIC SCENES IN GREENLAND ANI) ICELIND. Second Edition, $16 \mathrm{mo}, 2 \mathrm{~s}$.

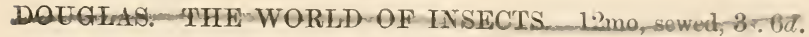

DOWDEN. WALKS AETER WHbD FLOWERS. Foolscap 8ro, 4s. 6d.

DREW. PRACTICAL METEOROLOGY. Seeond Edition, foolscap $8 v 0,5 s$. DRUMMOND. FIRST STEPS TO AN.TOMY. $12 \mathrm{mo}, 5 s$.

ELEMENTS OF PRACTICAL KNOWLEDGE. Second Edition, $1, \mathrm{mo}, 3 \mathrm{~s}$. ELIOT AND STORER. A MANUAL OF INORGANIC CHEMISTRY. Crown 8vo, 10s. $6 d$.

ENGLAND BEFORE THE NORMAN CONQUEST. 16mo, 2s. $6 d$. ENTOMOLOGISTS' ANNUAL, 1855-1868. Foolscap, 2s. 6d. eacl. ENTOMOLOGISTs' MONTHLY MAGAZINE. Nos. 1-48, $6 d$. each. EVENING THOUGHTS, BY A PHYSICTAX. Third Edition, 4s, 6d. EYTON. HISTORY OF THE OYSTER AND THE OYSTER-FISHERIES. $8 \mathrm{vo}, 5 s$.

FIRST PRINCTPLES OF RELIGION. 18mo, $2 . s$.

FLY-FISHING IN SALT AND FRESII WATER. sro, $7 s . G d$.

FORBES. HISTORY OF BRITISH STARFISHES. 8ro, $15 \mathrm{~s}$.

FORBES AND AUSTEN. NATURAL IISTORY OF THE EUROPEAY Seas. Foolscap 8ro, 5 s.

FORBES AND HANLEI. HISTORY OF BRTTISII MOLLCSCA AND their Shells. 4 vols. 8 vo, $£ 610$ s. Royal Sro, with the Plates Coloured, £'l3.

FRANKLAND. LECTURE-NOTES FOR CHEMICAL STUDENTS. Pust 8 ro, $12 s$.

GARNER. FIGURES OF INTERTEBRATE ANIMALS. Royal Sro, 5s. NATURAL IIISTORY
(with Supplement). 8 ro, 10 s.

GISSING. MATERIALS FOR A FLORA OF WAKEFIELD. sro, 1s. Gd. GOLDSMITH. VICAR OF WAKEFIELD. Illustrated by Mitureny. Second Edition, square 8vo, 10s. $6 \mathrm{~d}$.

GOODSIR. AN ARCTIC VOYAGE. Pust 8ro, 5̌s. (id.

GOSSE. AQUARIUM. Post 8 ro, $17 s$.

. HANDBOOK TO MARINE AQUARIUM. Foolscap Sro, "s.s. fid.

BIRDS OF JAMAICA. Post 8 ro, $10 s$.

BRITISI SEA-ANEMONES. 8ro, 21 s.

CANADIAN NATURALIST. Post sro, 12s.

DEVONSHIRE COAST. Post sro, $21 s$.

. MANUAL OF MARINE ZOOLOGY. 22 rols. feup Ero, 7s, fid. each. 
GOSSE. OMPHALOS. Post 8 ro, 10s. $6 d$.

- TENBY. Post 8ro, $21 s$.

GRAY'S BAPD. With Illustrations; uniform with the Elegy, post 8ro, $7 s$.

ELEGY IN A COUNTRY CHURCHYARD. With 33 Engravings, post $8 \mathrm{ro}, 9 s$; Polyglot Edition, 12s.; a small edition, foolscap 8vo, 2s.6d.

GRAY. SYNOPSIS OF THE SPECIES OF STARFISH IN THE British Museum. 4to, sewed, $7 s .6 d$.

GREG AND LETTSOM. MANUAL OF BRITISH MINERALOGY. 8ro, $15 s$. GRIFFITH AND HENFREY. MICROGRAPHIC DICTIONARY. Second Edition, 8ro, $£ 25$ s.

GRIFFITH. AN ELEMENTARY TEXT-BOOK OF THE MICROSCOPE. Post 8 ro, 7 s. $6 d$.

GROTIUS. INTRODUCTION TO DUTCII JURISPRUDENCE. Translated by Herbert. Royal $8 \mathrm{ro}, 31 s, 6 d$.

GURNex. CATAlogte OF RAPTORIAL BIRDS. Part 1, Imp.8ro, 5s. ON THE GREY PHALAROPE. 8ro, sewed, $6 d$.

HARDING. UNIVERSAL STENOGRAPHY. Foolscap 8vo, sewed, 3s.; bound, $3 s$. $6 d$.

HARTING. THE BIRDS OF MIDDLESEX. Post 8 ro, $7 s .6 d$.

HARIEY. BRITISH MARINE ALGE. 8ro, 21s.; Coloured, 31s. $6 d$. . FLORA CAPENSIS. 8vo, vols. i. \& ii., 12.s. each; vol. iii., $18 s$. THESAURUS CAPENSIS. Tols. i. \& ii., $21 s$, each. INDEX GENERUM ALGARUM. 8vo, sewed, 2s.6d.

NEREIS BOREALI AMERICANA. Royal 4to, sewed, £3 3 . SEASIDE BOOK. Fourth Edition, foolscap 8ro, 5s.

HASLAI. PERRAT-ZABULOE. THE CHURCH OF S. PIRAN. Foolscap 8 ro, $4 s .6 d$.

HENFREY. ELEMENTARY COURSE OF BOTANY. Post 8ro, 12s.6d. . RUDIMENTS OF BOTANY. Foolscap 8vo, $3 s .6 d$.

. SIX BOTANICAL DIAGRAMS FOR ILLUSTRATING Lectures, $15 \mathrm{~s}$.

. THE VEGETATION OF EUROPE. Foolscap 8 ro, $5 s$.

HEWITSON. COLOURED ILLUSTRATIONS OF THE EGGS OF British Birds. Third Edition, 2 rols. 8 ro, $£ 414 s .6 d$.

DESCRIPTION OF $100 \mathrm{~N}$
ridæ. Parts $1 \& 2$, 8ro, sewed, $6 d$. each.

EXOTIC BUTTERFLIES. Tols. i.-iii., 4to, £5 5s. each; continued in Quarterly 5s. Parts (66 published).

ILLUSTRATIONS OF DIURNAL LEIIDOPTERA. Parts 1-3, 4to, sewed, 25s. each. 
HINCKS. CATALOGUE OF THE ZOOPHYTES OF THE SOUTH OF Deron and Cormwall. 8ro, sewed, :3s.

HOLMESDALE NATURAL-IISTORY CLUB PROCEEDIXGS. 8 Vo, $1 s$. annually.

IIUNTER. ESSAYS AND OBSERVATIONS. Edited by OWEX. 2 vols. 8 ro, $31 s .6 d$.

IBIS. A QUARTERLY JOURNAL OF ORNITIOLOGY. Gs, each.

INSECTA SAUNDERSIANA. Parts 1-8, sro, sewed, 3s, each.

INSTRUMENTA ECCLESIASTICA. First and Second Series, 4to, sheep, $£ 111 s$. 6d. eaeh.

JEFFREYS. BRITISH CONCHOLOGY. Vols. i.-iv., post 8ro, 12.s each. (An Atlas containing Coloured Figures of all the Species is preparing.)

JENYNS. MEMOIR OF PROFESSOR HENSLOW. Post Sro, 7. 6d.

- OBSERVATIONS IN METEOROLOGY. Post 8ro, 10s, (jd. OBSERVATIONS IN NATURAL IIISTORY. Post Sro, 10. (id.

JESSE. AN ANGLER'S RAMBLES. Post 8 ro, $10 \mathrm{~s} .6 \mathrm{~d}$.

JOHNSTON. HISTORY OF BRITISH ZOOPIIYTES. 2 rols. sro, f‥ ㄹs.

INTRODUCTION TO CONCHOLOGY. 8ro, ㄹls.

Vol. i. (Botany), 8ro, 10s. 6d.

JONES. GENERAL OUTLINE OF THE ORGANIZATIOY OF THE Animal Kingdom. Third Edition, 8ro, £1 $11 \mathrm{~s}$. $6 \mathrm{~d}$.

. LECTURES ON THE NATURAL HISTORY OF ANIMLAS.

Vols. i. \& ii., post 8vo, 12s, each.

- THE AQUARIAN NATURALIST. Post 8ro, $18 s$.

KELAART. FLORA CALPENSIS. Sro, 10s.6d.

- PRODROMUS FAUNA ZEILANICE. 8vo, 10s. $6 d$.

KNOX. GREAT ARTISTS AND GREAT AN.ITOMISTS. Post $\&$ ro, 6s. $6 d$. . ORNITHOLOGICAL RAMBLES IN SUSSEX. Post Bro, Third Edition, $7 s .6 d$.

LATHAM. DESCRIPTIVE ETINOLOGY. 2 rols. Sro, $£ 1$ 12s.

- ETHNOLOGY OF BRITISH COLONIES. Foolsenp Ero, 5s.

- ETHNOLOGY OF BRITISII ISLINDS. Foolseap Sro, is.

- ETHNOLOGY OF EUROPE. Foolscap sro, 5 .

- ETINOLOGY OF INDIA. Evo, 16s.

- MAN AND HIS MIGRATIONS. Foolscap sro, $5 \varepsilon$.

- VARIETIES OF MAT. 8ro, $21 s$.

LEACH. STYOPSIS OF THE MOLLUSCA OF GREAT BRITAIY. Post 8ro, $14 s$. 
LETTERS FROM THE VIRGIN ISLANDS. Post 8 vo, $9 s .6 d$. LETTERS OF RUSTICUS ON NATURAL HISTORY. 8ro, $8 s .6 d$.

LOWE. FISHES OF MADEIRA. Parts 1-5, Royal 8ro, Coloured, 5s.; Demy 4to, Coloured, $7 s .6 d$. each.

MANUAL FLORA OF MADEIRA. Foolscap 8ro, sewed, Parts $1-4,3 s .6 d$. each.

TWO MEMIOIRS ON FERNS, LAND-SHELLS, ETC. OF MAdeira, $12 \mathrm{mo}, 6 s .6 d$.

LYNN. PRINCIPLES OF NATURAL PHILOSOPHY. Foolscap 8ro, $3 s$. MALAN. SYSTEMATIC CATALOGUE OF EGGS OF BRITISH BIRDS. Sro, $8 s .6 d$.

MARTIN. CATALOGUE OF PRITATELY PRINTED BOOKS. 8vo, $21 s$. MEYRICK. HOUSE-DOGS AND SPORTING-DOGS. Fcap 8vo, $3 s .6 d$. MOHL. ANATOMY AND PHYSIOLOGY OF THE VEGETABLE CELL. 8 ro, 7 s. $6 d$.

MOORE ANd MORE. CIBELE HIBERNICA. Post 8vo, 10s. $6 d$.

MOSLEY. NATURAL HISTORY OF TUTBURY. Royal 8vo, 21 .

MOULE. HERALDRY OF FISH. 8 ro, $21 s$; Royal 8 ro, for Colouring, $£ 22 s$.

NEWMAN. DICTIONARY OF BRITISH BIRDS. 8ro, 12s.

HISTORY OF BRITISH FERNS. Third Edition, 8ro, 18s.;

School Edition, foolscap $8 \mathrm{ro}, 5 \mathrm{~s}$.

HISTORY OF INSECTS. 8ro, 12 s.

cap 8 ro, 2 s. $6 z$.

NEWTON. OOTHECA WOLLETANA. Part 1, royal Sro, £1 $11 \mathrm{~s} .6 \mathrm{~d}$.

NORTHCOTE AND CHURCH. QUALITATIVE CHEMICAL ANALISIS. Post 8ro, 10s. 6d.

OWEN. BRITISH FOSSIL MAMMALS AND BIRDS. 8vo, £1 11s. $6 d$. ON PARTIIENOGENESIS. 8vo, $5 s$.

. ON THE MYLODON. Royal 4to, $£ 112 s .6 d$.

PALEI. MANUAL OF GOTHIC ARCHITECTURE. Feap 8ro, $6 s .6 d$. MANUAL OF GOTHIC MOLDINGS. Third Ed., 8ro, 7s.6d. THE CHURCH RESTORERS. Foolseap 8ro, $4 s .6 d$.

PENNELL. THE ANGLER-NATURALIST. Post 8 ro, 10s. $6 d$.

PLAYFAIR AND GÜNTHER. FISHES OF ZANZIBAR. Royal 4to, £3 $3 s$. POOR ARTIST, OR SEVEN EYESIGHTS AND ONE OBJECT. Foolscap 8 ro, $5 s$. 
PRESCOTT. TOBACCO AND ITS ADULTERATIONS. 8No, 12s. fil. PRESTON. FLORA OF MARLBOROUGII. 12mo, 3. f fic.

PRESTWICH. GEOLOGICAL INQUIRY RESPECTING TIIE WATER bearing Strata of the Country around London. sro, ss. fid.

TIIE GROUND BENEATII US. 8ro, sewed, 3s. fir.

RECORD OF ZOOLOGICAL LITERATURE. Sro, 30s, annually (186t-6i; published).

REFUGIUM BOTANICUM; FIGURES AND DESCRIPTIONS OF Little-known or New Plants. Royal 8ro, Part I, 7s. (irl. SALISBURY. GENERA PLANTARUM. A FRAGMENT, CONTAINING
part of Liriogame. 8Vo, 5s.

SAMUELSON. HUMBLE CREATURES. THE EARTHWORM AND Housefly. Sceond Edition, post 8 ro, $3 s, 6 d$. 8 vo, $6 s$.

IIUMBLE CREATURES. THE MONEY-BEE. Post

SEEMANN. BRITISH FERNS AT ONE TIEW. 8ro, Coloured, 6s.

SELBY. BRITISII FOREST-TREES. 8ro, $28 s$.

SHAKSPEARE'S SEVEN AGES OF MAN. Illustrated, square Sro, 6s. SHARPE. DECORATED WINDOW's. Sro, Plates, 21s.; Text, I0.s. fid.

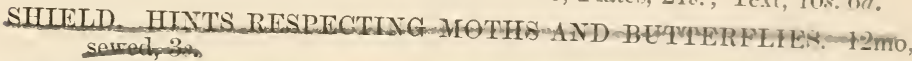
serred, $3 \%$

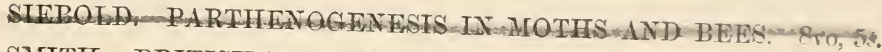

SMITH. BRITISH DIATOMACEE. 2 vols. royal Svo, £゚ 11 s. SOWERBY AND JOHNSON. BRITISH POISONOLS PLINTS. Post Ero,
$9 s .6 d$.

$£ 33 s$.

BRITISH WILD FLOWERS. Coloured, sro, SOWERBY. KEY TO THE NATURAL ORDERS OF BRITISII WILD
Flowers. 8ro, $7 s .6 d$.

$£ 15$ s. each.

THESAURUS CONCHYLIORUMI. Parts 1-25, Coloured,

SPRATT AND FORBES. TRATELS IN LYCIA. 2 rols. 8ro, £l Ifis,

SPRATT. TRAVELS AND RESEARCHES IN CRETE. 2 rols. sro, 노.

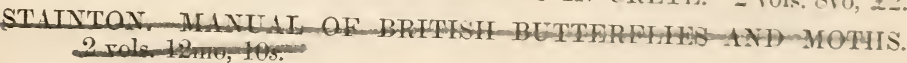

10 rols. 8 ro, 12s. 6 d. each.

- TINEINA OF SYRIA AND ASIA MINOR. Ero, ts. STRICKLAND AND MELVILLE. THE DODO AND ITS KINDRED.
4 to, $£ 1$ s. 
STRICKLAND. ORNITHOLOGICAL SYNONYMS. Tol. i. (Accipitres) 8 vo, $12 s .6 d$.

SUNDAY BOOK FOR THE YOUNG. 16mo, $2 s .6 d$.

THOUGHTS BY A PHYSICIAN: BEING A SECOND SERIES OF Erening Thoughts. Post 8 ro.

TUGWELL. MANUAL OF SEA-ANEMIONES. Post 8 ro, $7 s .6 d$.

TULK AND HENFREY. ANATOMICAL MANIPULATION. Fcap 8ro, $9 \mathrm{~s}$. WARD. HEALTHY RESPIRATION. Second Edition, foolscap, sewed, $1 s$. WATTS. DIVINE AND MORAL SONGS. Illustrated, square 8ro, 7 s.6d. WHITE. NATURAL HISTORY OF SELBORNE. Edited by Jexrss. Foolscap 8vo, 7s. $6 d$.

WILKINSON. BRITISH TORTRICES. 8ro, $25 s$.

WILKINSON, LADY. WEEDS AND WILD FLOWERS. Post8vo, 10s.6d. WILLIAMS. HANDBOOK OF CHEMICAL MANIPULATION. Post 8 vo, $15 s$.

WOLLASTON. COLEOPTERA ATLANTIDLM. 8ro, $21 s$.

- COLEOPTERA IIESPERIDUM. 8ro, 10s. $6 \mathrm{~d}$.

INSECTA MADERENSIA. Royal 4to, £2 $2 s$.
ON THE VARIATION-OF SPECIES. Post 8 Tro, $5 \mathrm{~s}$.

WOODWARD. ON POLARIZED LIGHT. Second Edition, 8 ro, $3 s$.

YARREAE. HISTORY OF BRITISI BIRDS. 3 rols. 8 ro, Third Edition, $£ 414 s .6 d$. $£ 33 s$.

HISTORY OF BRITISH FISIIES. 2 rols. 8ro, Third Edition, - ON THE SALMON. Oblong folio, sewed, $12 s$.

ZOOLOGTST. A JOLRNAL OF NATLRAL HISTORY.-1s. montly.

\section{In the press.}

THE MOCKING-BIRD AND OTHER POEMS, by Frederick Fıld, F.R.S. ELEMENTS OF IIEAT, by Frederick Geturie, Professor of Chemistry and Physics at the Royal College, Mauritius.

A HISTORY OF BRITISH HYDROID ZOOPHYTES, by the Rev. Tromas Hincks, B.A. 2 rols. 8 ro.

ON THE ARCHITECTURAL IIISTORY OF ELY CATIIEDRAL, by tho Rev. D. J. Stewart, M.A.

JOHN TAN VOOLST, 1 PATERYOSTER ROW. 





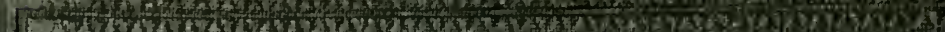

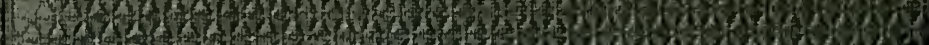

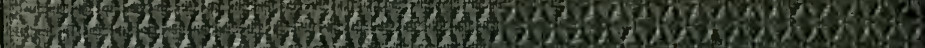

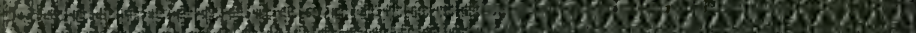

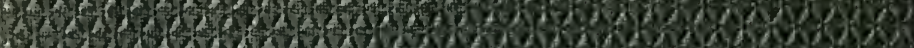

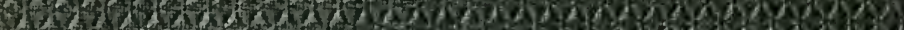

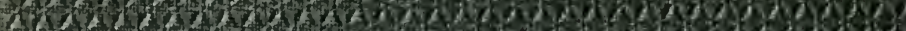

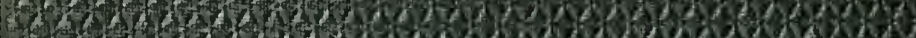

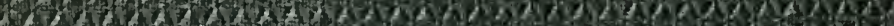

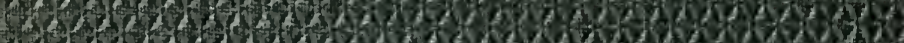

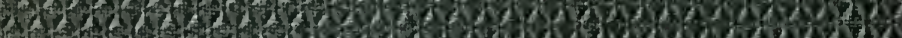

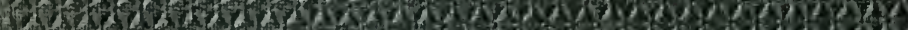

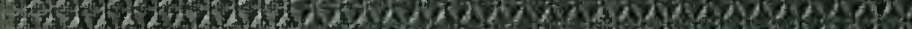

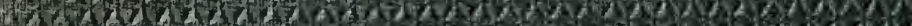

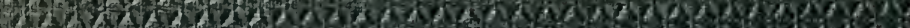

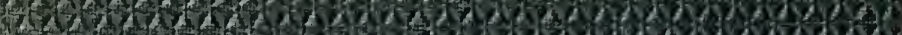

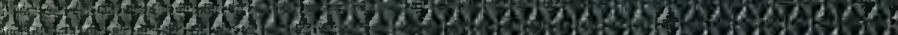

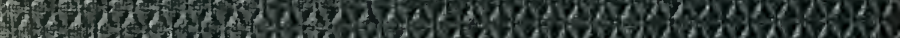

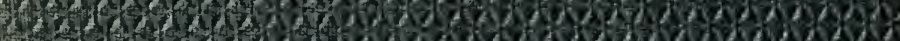

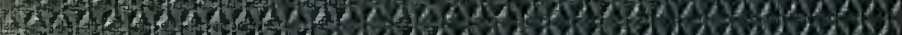

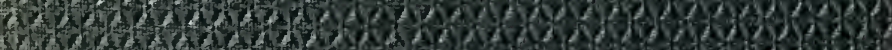

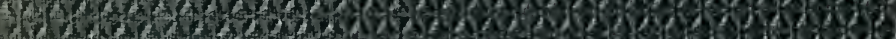

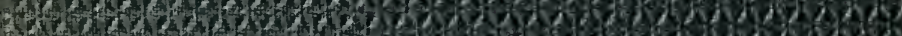

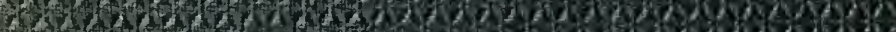

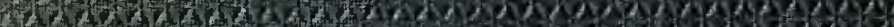

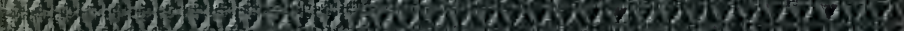

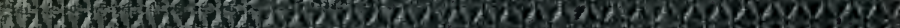

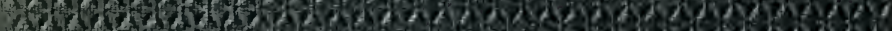

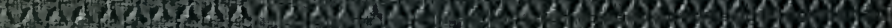

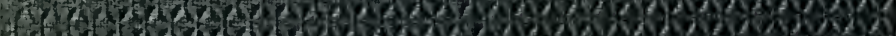

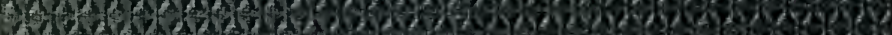

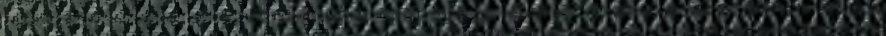

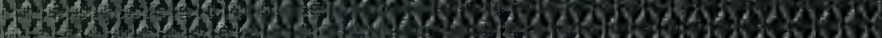

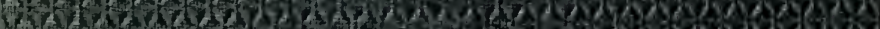

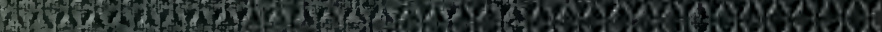

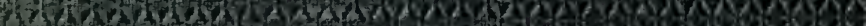

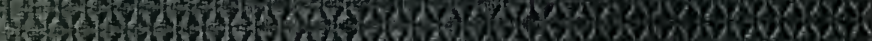

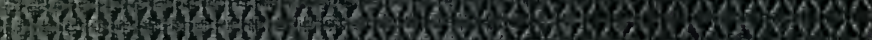

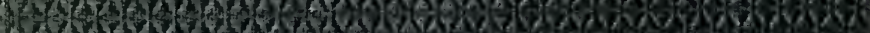

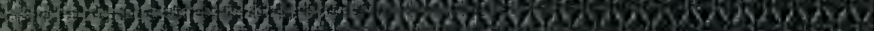

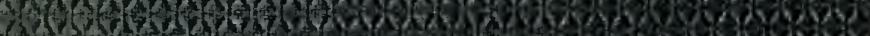

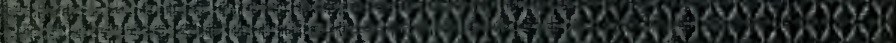

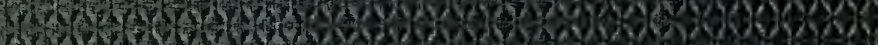

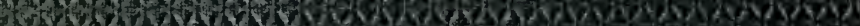

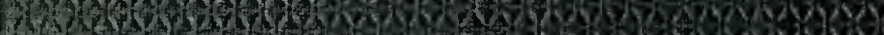

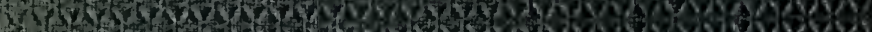

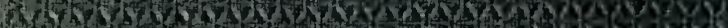

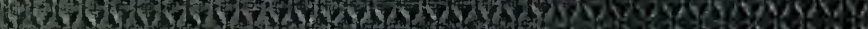

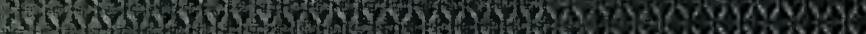

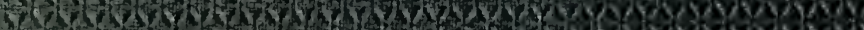

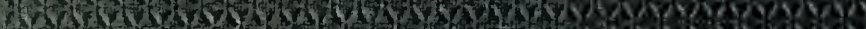

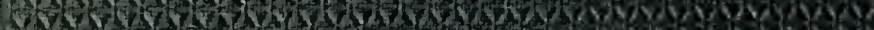

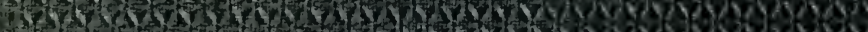

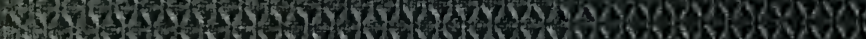

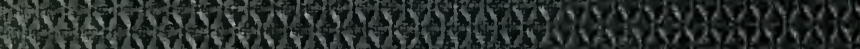

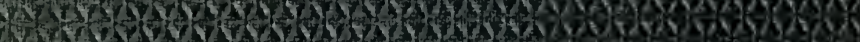

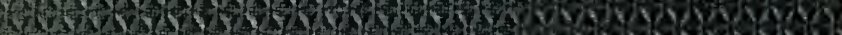

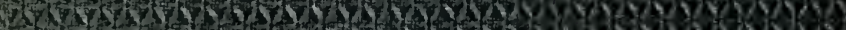

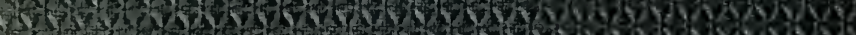

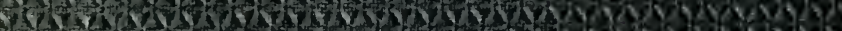

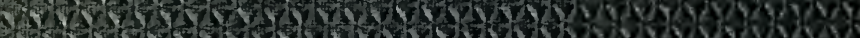

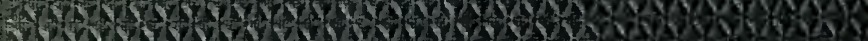

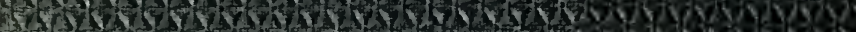

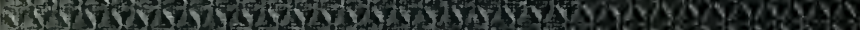

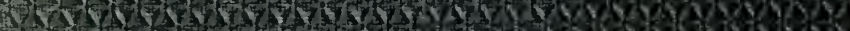

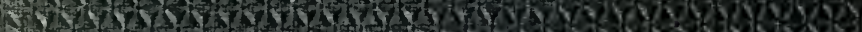

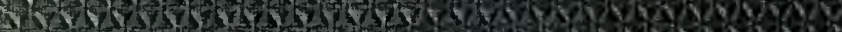

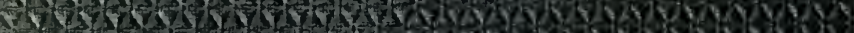

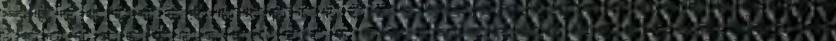

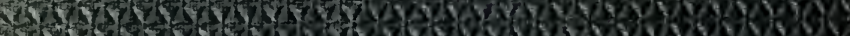

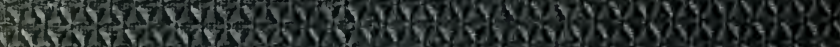
Ifs

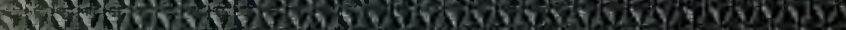

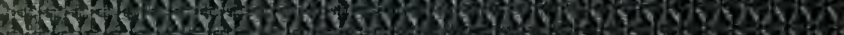

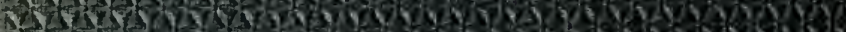

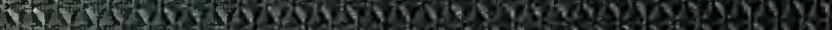

Hat for

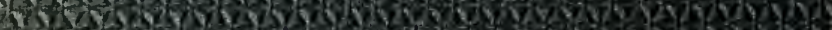

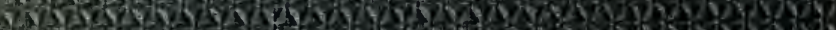

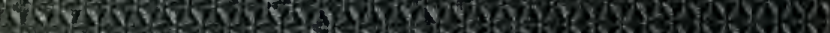

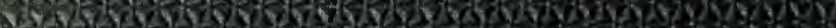

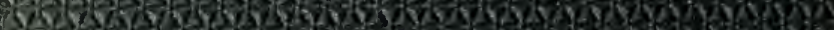

